NYPL RESEARCH LIBRARIES

33433081786703 



Digitized by the Internet Archive in 2008 with funding from Microsoft Corporation 



\title{
THE NATURAL HISTORY
}

AND THE

\section{TOPOGRAPHY}

\author{
$\mathrm{OF}$ \\ GROTON, MASSACHUSETTS
}

TOGETHER WITH OTHER MAT'TER RELATING TO THE HISTORY OF THE TOWN

BY

SAMUEL ABBOTT GREEN

$$
\text { [V. } I_{2}
$$

Facts lie at the foundation of history, and they are the raw material of all narrative writing

G R O T O N :

I9I 2 


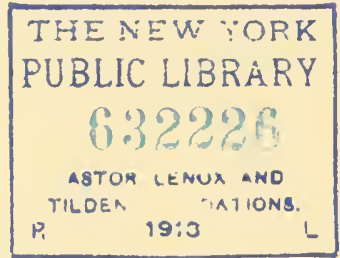

OAniversity 扔ress :

John Wilson and Son, Cambridge, U.S.A. 
TO

đூ) ftlemary

of

SAMUEL AUGUSTUS SHATTUCK

AND HIS WIFE

SARAH PARKER SHATTUCK

- HOTH Natives OF THE TOWN -

WITH WHOM MY PERSONAL ASSOCIATIONS DURING

THE LATER YEARS OF THEIR LIVES WERE

ALWAYS SO PLEASANT

THESE PAGES ARE INSCRIBED 



\section{INTRODUCTORY NOTE.}

With the exception of Miss Elizabeth Sewall Hill's paper on the Flora and Fanna of the town, and of a very few others that were first printed in newspapers, these several articles have already appeared in the Groton Historical Series. In the present form the opportunity has been taken to make certain changes in the text of such articles.

Miss Hill, by her knowledge and love of nature, is remarkably well fitted to describe the Flora and Fauna. The hills and valleys of the town, with all their shrubbery and other vegetation, and the brooks and meadows with their moats and swamps, are well-known to her; and the various animals that live on the land or in the water are equally familiar. The birds even seem to know that she is a lover of their species, and they are always ready to answer her calls when she imitates their notes. As a labor of love on her part, she has written this description, and, by her courtesy and kindness in the matter, she has placed me under special obligations.

I like to think of the hills and woods as animate objects who know their friends; and I never go into the fields and meadows without listening to their call. They have their own peculiar speech, and by close observation one can learn their dialect. I never stroll at random without heeding their words. Even the birds and the squirrels send messages which can be translated into our tongue. The running brooks and the stone walls all help us to learn these lessons, for they, too, take part in the drama. 
I have included in these pages a few short articles that, strictly speaking, do not come under the subjects given in the main title of the book. It has seemed to me proper, however, to bring them under cover, and in this way to save them, as they relate to matters closely connected with the early history of the town.

- MARCH 16, I9I2. 


\section{THE NATURAL HISTORY AND THE TOPOGRAPHY OF GROTON, MASSACHUSETTS.}

\section{FLORA.}

Nature, the old nurse, took

The child upon her knee, Saying: "Here is a story-book

Thy Father has written for thee.

"Come wander with me," she said, "Into regions yet untrod;

And read what is still unread In the manuscripts of God."

And he wandered away and away With Nature, the dear old nurse, Who sang to him night and day

The rhymes of the universe.

And whenever the way seemed long, Or his heart began to fail, She would sing a more wonderful song, Or tell a more marvelous tale.

LoNGFELlow to AgAssiz, on his golden birthday .

Groton has a widely varied Flora. Its beautiful trees have always been admired, especially the elms; not only those which add so much beauty to the Main Street, but also many in the outlying districts. Two of the largest as well as the oldest elms were set out in $\mathrm{I} 740$, - one in the grounds of $\mathrm{Mr}$. 
James Lawrence and the other in our own yard. An unusually beautiful purple beech is in the yard of Dr. Kilbourn. A large oak grows on the Reedy Meadow road. A larger maple stands in front of the Champney Place. A row of beautiful Norway spruces is near the Groton Paper Mill. Larches and pines grow in Mr. James Lawrence's grounds on the West Groton road. The willows on Broad Meadow Road form a pretty avenue. Besides these many private estates abound in native as well as cultivated varieties. Over ninety trees and shrubs, cultivated and wild, could be found eight years ago beside the road between my home and the top of Long Hill. Too little care is taken to preserve the native shrubs and many are destroyed. There are many old-fashioned gardens as well as the more formal ones.

The Groton Improvement Society has done much toward keeping the small parks in good condition, setting out shrubs, providing rubbish barrels, giving money to promote school gardening and nature study. The Groton children have won many prizes at the School Garden Competitions of the Massachusetts Horticultural Society in Boston, not only for the best school and home gardens but also for the best display of vegetables and for the best herbariums.

The third and fourth grades of the Butler School have found every tree included in the Course of Study, growing between the Public Library and the Baptist Church. It is hoped that in the near future a School Garden may be started on the Lawrence Playground in connection with the vegetable and flower gardens, where every native tree, shrub and plant may be represented.

It is well to begin with the lowest forms of plant life and ascend the scale. The smaller are the more numerous. The following classes include the whole vegetable kingdom, each being represented by at least one species in Groton : 


\begin{tabular}{|c|c|c|c|c|c|}
\hline Thallophyta & . & - & - & $\cdot$ & $\begin{array}{l}\text { Algae } \\
\text { Fungi } \\
\text { Lichens }\end{array}$ \\
\hline BRYOPHYTA . & $\cdot$ & . & - & · & $\begin{array}{l}\text { Mosses } \\
\text { Hepaticae }\end{array}$ \\
\hline Pteridophita & . & $\cdot$ & - & . & $\begin{array}{l}\text { Ferns } \\
\text { Horsetails } \\
\text { Club-Mosses }\end{array}$ \\
\hline Giminospermae & - & . & - & - & Pines, etc. \\
\hline ANGIOSPERMAE & - & . & . & . & $\begin{array}{l}\text { Grasses } \\
\text { Plants } \\
\text { Shrubs } \\
\text { Foliage Trees }\end{array}$ \\
\hline
\end{tabular}

There are many kinds of Algae, such as slime, moulds and yeast bacteria. Spirogyra, or Green Pond Scum, is a very common example. The green mould on rocks and old stone walls is another species. Many Fungi, Toadstools or Mushrooms may be seen. Coral Mushrooms may be found in pine woods. The Polyporeae, also called the Bracket Fungi, attack trees. Puff Balls and Earth Stars grow on the ground. Besides these are many commonly known as Toadstools or Mushrooms. The Lichens form a higher class of Thallophytes and are often taken for Mosses. They are found on trees, rocks and in damp places. The most common are the Usnea barbata, or Beard Lichen, growing on trees, and the Xanthoria parietina, which forms little round mats on the bark of trees. The bright red, coral-like, little Cladonia coccifera is found in damp places and on stumps. In the Bryophyta class are the Liverworts and Mosses. The Liverworts may be found on stones, wood, etc., in wet places and are very numerous, as are also the Mosses. The Sphagnum and Pigeon Wheat Mosses are those most commonly seen. In the Pteridophyta class are the Ferns, Horse-tails and Club-Mosses. The Ferns are many and beautiful. They are so repeatedly cut back on the roadside that much beauty has been destroyed. Some varieties, like the Maidenhair and 
Climbing Ferns, have been almost exterminated by man for decorations. The following species may be found in Groton:

Polypody Fern. Polypodium vulgare. Rockwood's pasture. July I.

Maidenhair. Adiantum pedatum. Moist woods and hillsides. July 4 .

Common Brake. Pteris aquilina. Meadows. August I.

Cliff-Brake. Pellaea gracilis. Black Pond. July I.

Pellaea atropurpurea. Rockwood's pasture. July.

Chain Fern. Woodwardia Virginica. Ayer road. July.

Maidenhair Spleenwort. Asplenium Trichomanes. Rockwood's pasture. July.

Spleenwort. Asplenium ebeneum. Rockwood's pasture. July.

Silvery Spleenwort. Asplenium thelypteroides. Rockwood's pasture. July.

Lady Fern. Asplenium Filix-foemina. Quasoponagon meadows. July.

Walking-Leaf. Camptosorus rhizophyllus. By river. July.

Beech Fern. Phegopteris polypodioides. Woods. July.

Phegopteris hexagonoptera. Woods. July.

Phegopteris Dryopteris. Woods. July.

Shield Fern. Aspidium Thelypteris. Quasoponagon meadows. August.

Aspidium spinulosum. Woods. July.

Aspidium intermedium. Rockwood's pasture. July.

Aspidium Bootii. Rockwood's pasture. July.

Aspidium cristatum. Quasoponagon meadows. July.

Aspidium Clintonanum. Quasoponagon meadows. July.

Aspidium Goldianum. Quasoponagon meadows. July.

Aspidium marginale. West Groton road. August.

Christmas Fern. Aspidium acrostichoides. Rockwood's pasture. July.

Bladder Fern. Cystopteris bulbifera. Woods. July.

Sensitive Fern. Onoclea sensibilis. Quasoponagon meadows. July.

Onoclea Struthiopteris. Woods. July.

Woodsia obtusa. Black Pond. July.

Woodsia Ilvensis. Rockwood's pasture. June.

Dirksonia pilosiuscula. Quasoponagon meadows. July.

Lygodium palmatum. Climbing Fern. Nashua River bank. September. 
Flowering Fern. Osmunda regalis. Elm Avenue. May.

Interrupted Fern. Osmunda Claytoniana. Elm Avenue. May.

Cinnamon Fern. Osmunda cinnamomea. Elm Avenue. May.

\section{ADDER'S TONGUE FAMILY.}

Botrychium Lunaria. Black Pond. June.

Botrychium lanceolatum. Black Pond. June.

Botrychium ternatum. Pine Avenue. June.

\section{CLUB MOSS FAMILY.}

Lycopodium Selago. Quasoponagon meadows. August.

Lycopodium lucidulum. Pine woods. August.

Lycopodium inundatum. Woods. August.

Lycopodium obscurum. Woods. July.

Common Club-Moss. Lycopodium clavatum. Pine woods. July.

Ground-Pine. Lycopodium complanatum. Woods. July.

Club-Moss is used very extensively for Christmas decorations, and there is great danger of its extermination.

Sellaginella apus. Low fields.

Quillwort. Isoetes lacustris: Quasoponagon meadows. July.

HORSETAILS.

Common Horsetail. Equisetum arvense. Long Hill. March.

Equisetum limosum. Quasoponagon meadows. June.

Equisetum hyemale. Scouring Rush. Used for scouring pewter, etc. Nashua River bank. June. 


\section{FLOWERS AND PLANTS.}

Flower in the crannied wall,

I pluck you out of the crannies,

I hold you here, root and all, in my hand,

Little flower - but if I could understand

What you are, root and all, and all in all,

I should know what God and man is.

Clematis. Virgin's Bower.

Clematis Virginiana. Common. Roadsides. July I 4.

Anemone. Wind Flower. Anemone Virginiana. Uncommon. Roadsides. July 20.

Wood Anemone. Anemone nemorosa. Common in woods. April I 8.

Hepatica. Liver-Leaf. Hepatica triloba. Common. Rocky woods. April 2.

Hepatica acutiloba. Rare. April.

Rue Anemone. Anemonella thalictroides. Love Lane. July 26.

Meadow-Rue. Early Meadow-Rue. Thalictrum dioicum. Roadsides. May.

Tall Meadow-Rue. Thalictrum polygamum. Roadsides. May 29.

Purple Meadow-Rue. Thalictrum purpurascens. Roadsides. June 15.

White Water-Crowfoot. Ranunculus aquatilis trichophyllus. Ponds. June.

Yellow Water-Crowfoot. Ranunculus multifidus. The Eddy. May.

Ranunculus septentrionalis. Common in wet places. May.

Bristly Buttercup. Ranunculus Pennsylvanicus. Common in wet places. June.

Bulbous Crowfoot or Buttercup. Ranunculus bulbosus. Fields and pastures. May I I.

Tall Crowfnot or Buttercup. Ranunculus acris. Fields and roadsides. May 15.

Marsh Marigold. Caltha palustris. Wrangling Brook. April is. Brooks and meadows.

Goldthread. Coptis trifolia. Our woods. May 10.

Wild Columbine. Aquilegia Canadensis. Rocky pastures. May I7.

Garden Columbine. Aquilegia vulgaris. Escaped. June.

Red Baneberry. Actaea spicata. North End. April 20. 
White Baneberry. Actaea alba. Rare. May 15 .

Barberry. Berberis vulgaris. Lowell road. May 15 .

Sweet-Scented Water-Lily. Nymphaea odorata. Ponds and rivers. June 20.

Yellow Pond-Lily. Cow Lily. Spatter-Dock. Nuphar advena. Nashua River. Eddy and other ponds. May ro.

Pitcher-Plant. Side-Saddle Flower. Huntsman's Cup. Sarracenia purpurea. Meadows. June 2.

Blood-Root. Sanguinaria Canadensis. Long Hill. April 16.

Celandine. Chelidonium majus. Roadsides, damp places. Nay I8.

Dutchman's Breeches. Dicentra Cucullaria. Our yard. April ro.

Pale Corydalis. Corydalis glauca. Throne. May 20.

Common Fumitory. Fumaria officinalis. Waste places. May.

Horseradish. Nasturtium Armoracia. Moist places. June 30.

Whitlow-Grass. Draba verna. Rockwood's pasture. April 16 .

Field Mustard. Brassica Sinapistrum. Grain fields. June I.

Winter-Cress. Barbarea viulgaris. James's Brook. May II.

Shepherd's Purse. Capsella Bursa-Pastoris. Roadsides. April 20.

IVild Peppergrass. Lepidium Virginicum. Roadsides. June.

Wild Radish. Raphanus Raphanistrum. Fields. June ro.

Rock-Rose. Helianthemum Canadense. Pasture by river. June ro.

Birdfoot Violet. Viola pedata. North End. Sandy soil. May 9.

Common Blue Violet. Viola palmata. Roadsides and woods. April 30.

Common Blue Violet. Viola curcullata. Roadsides and woods. April 30.

Arrow-Leaved Violet. Viola sagittata. Rockwood's pasture. April 20.

Sweet White Violet. Viola blanda. Wet places. April 29.

Sweet Violet. Viola odorata. Main Street. Escaped. April 30. Viola blanda palustriformis. Wet places. May 3.

Primrose-Leaved Violet. Viola primulaefolia. Martin's Pond. June $\mathrm{r}$.

Lance-Leaved Violet. Viola lanceolata. Wet places. May 9.

Downy Yellow Violet. Viola pubescens. Nashua River bank. Nay $\mathbf{r}$.

Dog Violet. Viola canina. Quasoponagon meadows. April 30. Heart's-Ease. Johnny-Junip-Up. Viola tricolor. Escaped. May 20.

Deptford Pink. Dianthus Armeria. Escaped. July. 
Sweet William. Dianthus barbatus. Escaped. July.

Bouncing Bet. Soapwort. Saponaria officinalis. Fields and roadsides. July 5 .

Bladder Campion. Silena Cucubalus. Fields. July 1 o.

Wild Pink. Silena Pennsylvanica. Fields. July 3.

Night-Flowering Catchfly. Silena noctiflora. Fields. July 29.

Common Chickweed. Stellaria media. Damp places. July I.

Long-Leaved Stitchwort. Stellaria longifolia. Damp places. June 5.

Mouse-Ear Chickweed. Cerastium viscosum. Fields. May 15.

Field Chickweed. Cerastium arvense. Fields. May 20.

Sand Spurry. Buda rubra. Roadsides. July ro.

Purslane. Portulaca oleracea. Cultivated fields. July 5.

Spring-Beauty. Claytonia Virginica. Rare. May I.

St. John's-Wort. Hypericum ellipticum. Wet places. June 20.

Common St. John's-Wort. Hypericum perforatum. Fields. June 27 .

St. John's-Wort. Hypericum maculatum. Meadows. July I.

Orange-Grass. Pine-Weed. Hypericum nudicaule. Sandy roadsides. June.

Small St. John's-Wort. Hypericum mutilum. Quasoponagon meadows. June.

Marsh St. John's-Wort. Elodes campanulata. Swamps. July.

Common Mallow. Malva rotundifolia. Door-yards and waste places. June 6 .

Musk Mallow. Malva moschata. Escaped. July ı.

Common Flax. Linum usitatissimum. Cultivated fields. August 3 .

Wild Geranium. Wild Cranesbill. Geranium maculatum. Roadsides. May 10.

Herb Robert. Geranium Robertianum. Rare. June.

Ladies' Sorrel. Yellow Wood Sorrel. Oxalis corniculata. Also variety stricta. Fields and roadsides. June I .

Common Wood-Sorrel. Oxalis Acetosella. Rare. Wood. June.

Pale Touch-Me-Not. Jewel-Weed. Impatiens pallida. Wet places. July го.

Spotted Touch-Me-Not. Impatiens fulva. Roadsides. July.

Black Alder. Winterberry. Ilex verticillata. Long Hill. May 20.

Wax-Work. Climbing Bitter-sweet. Celastrus scandens. Love Lane. June ro.

New Jersey Tea. Red-Root. Ceanothus Americanus. North End. June ro.

Northern Fox-Grape. Vitis Labrusca. Nashua River bank. June I . 
Summer Grape. Vitis aestivalis. Nashua River bank. May I 5 . Frost Grape. Vitis cordifolia. Nashua River bank. May Io. . Virginia Creeper. IVoodbine. Ampelopsis quinquefolia. Nashua River bank. July I.

Fringed Polygala. Polygala paucifolia. Woods. May 5.

Common Polygala. Polygala sanguinea. Fields. June 20.

False Indigo. Baptisia tinctoria. Roadsides. July 7.

Wild Lupine. Lupinus perennis. West Groton Paper Mill. May 24.

Rabbit-Foot Clover. Stone Clover. Trifolium arvense. Roadsides. July $\mathbf{~}$.

Red Clover. Trifolium pratense. Fields and roadsides. May 26.

White Clover. Trifolium repens. Fields and roadsides. May 20.

Yellow Clover or Hop-Clover. Trifolium agrarium. Fields and roadsides. June 3 .

Low Hop-Clover. Trifolium procumbens. Roadsides. July 30.

Sweet Clover. Yellow Melilot. Melilotus officinalis. Fields and roadsides. May 8 .

Sweet White Clover. Melilotus alba. Fields and roadsides. June 20.

Lucerne. Alfalfa. Medicago sativa. Lawrence Playground. September 10.

Black Medick. Medicago lupulina. Broad Meadow. July I.

Hoary Pea. Goat's Rue. Tephrosia Virginiana. Chicopee Row. June 20.

Tick-Trefoil. Desmodium nudiflorum. Roadsides. August r.

Tick-Trefoil. Desmodium acuminatum. Woods. July.

Desmodium ciliare. July 30 .

Desmodium rotundifolium. Rocky woods. July 28 .

Desmodium Canadense. Roadsides. July 8.

Bush-Clover. Lespedeza violacea. Red Bridge. August I .

Bush-Clover. Lespedeza polystachya. Roadsides. August I.

Bush-Clover. Lespedeza procumbens. Roadsides. August 20.

Bush-Clover. Lespedeza capitata. Roadsides. July.

Bush-Clover. Lespedeza reticulata. Fields and roadsides. June $3 \mathbf{r}$.

Vetch. Vicia Cracca. Roadsides. August I.

Common Vetch or Tare. Vicia sativa. Fields. August I.

Wild Bean. Ground-Nut, Apios tuberosa. The Crescent. July 30 .

Wild Bean. Phaseolus perennis. Thickets. August.

Hog Pea-Nut. Amphicarpaea monoica. Damp woods. August 30.

Wild Senna. Cassia Marilandica. Lower Ayer road. July 20. 
Common Meadow-Sweet. Spiraea salicifolia. Quasoponagon meadows. June 20.

Steeple-Bush. Spiraea tomentosa. Pasture by river. July I 4.

Purple Flowering-Raspberry. Rubus odoratus. Rare. July 29.

Common High Blackberry. Rubus villosus. Thickets. May 7.

Low Blackberry. Dewberry. Rubus Canadensis. Woods. July.

Running Swamp-Blackberry. Rubus hispidus. Woods. July.

Dalibarda repens. Our woods. July 20.

Avens. Geum album. Quasoponagon meadows. May 25.

Water Avens. Geum rivale. Quasoponagon meadows. May 20.

IVild Strawberry. Fragaria Virginiana. Fields and meadows. April 20.

Five-Finger. Potentilla arguta. Rockwood's pasture. April I 2.

Silvery Cinque-foil. Potentilla argentea. Red Bridge. June 3.

Shrubby Cinque-foil. Potentilla fruticosa. Lower Ayer road. July 30 .

Three-Toothed Cinque-foil. Potentilla tridentata. Elm Avenue. June io.

Common Cinque-foil or Five-Finger. Potentilla Canadensis. Fields and roadsides. April 30.

Common Agrimony. Agrimonia Eupatoria. Roadsides. July I.

Wild Rose. Rosa blanda. Rockwood's pasture. June $\mathbf{6} 6$.

Carolina Rose. Rosa Carolina. June 20.

Rosa lucida. June $2 \mathrm{I}$.

Rosa humilis. River pasture. June 15 .

Rosa canina. Red Bridge. June 30.

Sweetbrier. Eglantine. Rosa rubiginosa. Foot of Long Hill. June 28 .

Choke-Perry. Pyrus arbutifolia. Roadsides. May го.

Early Saxifrage. Saxifraga Virginiensis. Rockwood's pasture. April 18.

False Mitre-wort. Tiarella cordifolia. Black Pond. May i 2.

Mitre-wort. Bishop's-Cap. Mitella diphylla. Black Pond. June 20.

Wild Black Currant. Ribes floridum. Woods. June 20.

Ditch Stone-crop. Penthorum sedoides. Ditches. July 30.

Garden Orpine. Live-for-ever. Aaron's Rod. Pudding Bag. Witch's Money Bag. Blowers. Sedum Telephium. Roadsides. July 1.

Round-Leaved Sundew. Drosera rotundifolia. July i 7 .

American Sundew. Drosera intermedia. Our woods. June I 7 . 
Deer-Grass. Meadow-Beauty. Rhexia Virginica. Fields. July 23.

Swamp Loosestrife. Decodon verticillatus. Quasoponagon meadows. August 20.

Fire-weed. Great Willow-herb. Epilobium angustifolium. Red Bridge. June 20 . Burned and newly cleared land.

Fire-weed. Epilobium lineare. Wet bogs. July 30. Newly cleared land.

Fire-weed. Epilobium hirsutum. Burned land. July 3.

Fire-weed. Epilobium coloratum. Wet places. July 3 I.

Common Evening Primrose. Oenothera biennis. Readsides. June 20.

Oenothera pumila. Roadsides. June 3 .

Sundrops. Oenothera fruticosa. Quasoponagon meadows. June 7 .

Meadow-Parsnip. Thaspium aureum. Meadows. May 8.

One-Seeded Bur-Cucumber. Sicyos angulatus. Broad Meadow. August 5 .

Carrot. Daucus Carota. Fields and roadsides. June 7.

Cow-Parsnip. Heracleum lanatum. Quasoponagon meadows. June 2 .

Parsnip. Pastinaca sativa. Roadsides and meadows. June i 7 .

Water-Parsnip. Sium circutaefolium. Meadows. Wrangling Brook. June 19.

Meadow-Parsnip. Zizia aurea. Meadows. May $\mathbf{~}$

Caraway. Carum Carui. Broad Meadow. June 4.

Spotted Cowbane. Musquash Root. Beaver Poison. Circuta maculata. Elm Avenue. August 2.

Poison Hemlock. Conium maculatum. Elm Avenue. June 24. Sweet Cicely. Osmorrhiza longistylis. Roadsides. June.

Water Penuywort. Hydrocotyle Americana. James's Brook. July $\mathbf{~ . ~}$

Wild Sarsaparilla. Aralia nudicaulis. The Grove. May 17.

Dwarf Ginseng. Aralia trifolia. Our woods. May 9.

Bunch-Berry. Dwarf Cornel. Cornus Canadensis. Our woods. May 26.

Honeysuckle. Lonicera glauca. Elm Avenue. July 2.

Bush-Honeysuckle. Diervilla trifida. Roadsides. West Groton. June 9 .

Bluets. Innocence. Quaker Lady. Houstonia coerulea. Fields and roadsides. April 20. 
Button-Bush. Cephalanthus occidentalis. Quasoponagon meadows. July i 5 .

Partridge-Berry. Mitchella repens. Pine woods. June I4.

Cleavers. Goose-Grass. Galium Aparine. Quasoponagon meadows. July 20.

Small Bedstraw. Galium trifidum. Meadows. July I3.

Rough Bedstraw. Galium asprellum. Meadows. June 20.

Joe-Pye-IVeed. Eupatorium purpureum. Quasoponagon meadows. July 20.

Thoroughwort. Boneset. Eupatorium perfoliatum. Quasoponagon meadows. August 7 .

White Snake-root. Eupatorium ageratoides. Meadows. August.

Golden Rod. Solidago squarrosa. Shattuck's corner. August 5 .

Solidago bicolor. Roadsides. August 20.

Solidago speciosa. Roadsides. August 20.

Solidago odora. Sweet Golden Rod. Roadsides. August I5

Solidago rugosa. Roadsides. August ${ }^{5}$.

Solidago ulmefolia. Fields. August 29.

Solidago arguta. Roadsides. July i 6.

Solidago juncea. Roadsides. September 2.

Solidago serotina. Roadsides. August 25.

Solidago rigida. Roadsides. August 29.

Solidago lanceolata. Roadsides. August 5 .

Solidago latifolia. Roadsides. August 20.

Tall White Aster. Aster umbellatus. Roadsides. August 30.

Aster corymbosus. Red Bridge. August 2 I .

New England Aster. Aster Novae-Angliae. Rare. August I.

Aster patens. Roadsides. September 3 .

Aster cordifolius. August 30 .

Aster sagittifolius. Roadsides. September 3 .

Aster multiflorus. Roadsides. August 20.

Aster linariifolius. Roadsides. September 5 .

Aster puniceus. Roadsides. September 5 .

Horse-Weed. Butter-Weed. Erigeron Canadensis. Fields and roadsides. May 20.

Daisy Fleabane. Sweet Scabrious. Erigeron annuus. Fields and roadsides. June 3 .

Daisy Fleabane. Erigeron strigosus. Fields. June 3 .

Robin's Plantain. Erigeron bellidifolius. Long Hill. May 2 I .

Common Fleabane. Erigeron Philadelphicus. Roadsides. June 10. 
Plantain-Leaved Everlasting. Antennaria plantagenifolia. Rockwood's pasture. April $\mathbf{0}$.

Pearly Everlasting. Anaphilis margaritacea. Dry hills. July I 3 .

Common Everlasting. Gnaphalium polycephalum. River pasture. August I.

Low Cudweed. Gnaphalium uliginosum. Roadsides. August 2.

Elecampane. Inula Helenium. Lower Ayer road. July jo.

Great Ragweed. Ambrosia trifida. River bank. August r.

Roman Wormwood. Hog-weed. Ambrosia artemisiaefolia. Everywhere. August I.

Cone-Flower, Black-Eyed Susan. Rudbeckia hirta. Fields. June 4 .

IVild Sunflower. Helianthus strumosus. River bank. June 7 .

IVild Sunflower. Helianthus divaricatus. Roadsides. August I.

Wild Sunflower. Helianthus decapetalus. Thickets. August.

Jerusalem Artichoke. Helianthus tuberosus. North End. June r.

Bur-Marigold. Stick-Tight. Common Beggar-Ticks. Bidens frondosa. Damp places. Septèmber I.

Swamp Bur-Marigold. Bidens connata. Swamps. August I.

Smaller Bur-Marigold. Bidens cernua. Meadows. July r.

Larger Bur-Marigold. Bidens chrysanthemoides. Meadows. August 15 .

Water Marigold. Bidens Beckii. Meadows. August ro.

May-Weed. Chamomile. Anthemis Cotula. Roadsides. June 25.

Common Yarrow. Milfoil. Achillea millefolium. Fields and roadsides. July I.

White Daisy. Ox-Eye. White-Weed. Chrysanthemum leucanthemum. Fields. June 5.

Common Tansy. Tanacetum vulgare. Roadsides. July I 4.

Common Mugwort. Artemisia vulgaris. August I. Roadsides.

Wormwood. Artemisia Absinthium. Roadsides and waste places. August 6.

Golden Ragwort. Squaw-Weed. Senecio aureus. May 20.

Burdock. Actium Lappa. Waste places. July $\mathbf{r} 2$.

Common Thistle. Cnicus lanceolatus. Roadsides and waste places. July i 7 .

Swamp Thistle. Cnicus muticus. Pastures. July 20.

Canada Thistle. Cnicus arvensis. Long Hill. July I 2.

Bluebottle. Star-Thistle. Centaurea Cyanus. Waste places. July 10. 
Dwarf Dandelion. Krigia Virginica. Rockwood's pasture. April 29.

Chicory. Succory. Cichorium Intybus. Long Hill. June 28.

Fall Dandelion. Hawkbit. Leontodon autumnalis. Roadsides. June ro.

Deril's Paint Brush. Hieracium aurantiacum. Roadsides. Rare. Fields. June 25 .

Rattlesnake-Weed. Hieracium venosum. Roadsides. August I.

Hieracium scabrum. Roadsides. August I.

White Lettuce. Rattlesnake-root. Prenanthes alba. Roadsides. August 2.

Lion's Foot. Gall-of-the-earth. Prenanthes serpentaria. Roadside. August 10.

Tall White Lettuce. Prenanthes altissima. Roadsides. August 20.

Common Dandelion. Taraxacum officinale. Roadsides and lawns everywhere. April 25.

Wild Lettuce. Lactuca Canadens's. Roadsides. July 7.

Common Sow-Thistle. Sonchus oleraceus. Roadsides and waste places. August 10.

Cardinal-flower. Lobelia cardinalis. Nashua River banks and Wrangling Brook banks. August 2 .

Lobelia spicata. Elm Avenue. June ro

Indian Tobacco. Lobelia inflata. Elm Avenue. July 5.

Marsh Bell Flower. Campanula aparinoides. Quasoponagon meadows. August 4 .

Campanula rapunculoides. Roadsides. July $\mathbf{~} 0$.

Black Huckleberry. Gaylussacia resinosa. Duck Swamp. May ıо. Swamps.

Dwarf Huckleberry. Vaccinium Pennsylvanicum. Pastures. May 1 .

Low Blueberry. Vaccinium vacillans. Dry places. May 5.

Common Swamp-Blueberry. Vaccinium corymbosum. Pastures. May $\mathbf{~ . ~}$

Large American Cranberry. Vaccinium macrocarpon. Quasoponagon meadows. June 10.

Creeping Snowberry. Chiogenes serpyllifolia. North End. May 23. Rare.

Bearberry. Arctostaphylos Ura-ursi. Mr. James Lawrence's woods. May 30. Rare.

May Flower. Trailing Arbutus. Epigaea repans. Pastures. April I. 
Creeping Wintergreen. Checkerberry. Gaultheria procumbens. Woods. July 7 .

Andromeda polifolia. North End. May 20.

Andromeda ligustrina. Birch Plain. Pastures. July 5.

Leucothoe racemosa. North End. June 1.

Leather-Leaf. Cassandra calyculata. Rockwood's pasture. A pril I 2. Sheep Laurel. Lambkill. Kalmia angustifolia. Pastures. June 4. Pale Laurel. Kalmia glauca. North End. May 27.

Clammy Azalia. White Swamp-Honeysuckle. Rhododendron viscosum. June 17 .

Pinxter Flower. Purple Azalia. Rhododendron nudiflorum. Our woods. May 24.

Rhodora. Rhododendron Rhodora. Pastures. May 20.

White Alder. Sweet Pepperbush. Clethra alnifolia. Nashua River bank. July 22.

Princes Pine. Chimaphila umbellata. Woods. July I.

Spotted Wintergreen. Chimaphila maculata. Black Pond. July 30. One-Flowered Pyrola. Moneses grandiflora. Black Pond, June 10. Pyrola rotundifolia. Our woods. June 28.

Shin-Leaf. Pyrola. Pyrola elliptica. Woods. June 28. Indian Pipe. Monotropa uniflora. Our woods. July Io.

Pine-Sap. False Beech-Drops. Monotropa Hypopitys. Mr. James Lawrence's woods. June ro.

Star-flower. Chickweed-Wintergreen. Trientalis Americana. Our woods. May 16.

Steironema ciliatum. Elm Avenue. July $\mathbf{~} 0$.

Four-Leaved Loosestrife. Lysimachia quadrifolia. Elm Avenue. July io.

Moneywort. Lysimachia nummularia. Damp places. July I. Water Pimpernel. Brook-Weed. Samolus Valerandi. Wet places. May 26.

Dogbane. Indian Hemp. Apocynum cannabinum. Roadsides. June ro.

Butterfy-weed. Pleurisy-root. Asclepias tuberosa. Mr. Charles Lawrence's corner. July i 3.

Purple Milkweed. Asclepias purpurascens. Meadows. July r.

Common Milkweed. Silkweed. Asclepias Cornuti. Roadsides. June i 5 .

Swamp Milkweed. Asclepias incarnata. Meadows. July 1. Milkweed. Asclepias quadrifolia. Long Hill. June $\mathbf{1} 7$. 
Fringed Gentian. Gentiana crinita. Meadows. September 20. Closed Gentian. Gentiana Andrewsii. Elm Avenue. August 25. Buckbean. Menyanthes trifoliata. North End. May i 5 .

Forget-me-not. Myosotis palustris. James's Brook. May i 8.

Common Comfrey. Symphytum officinale. Broad Meadow. May I 2.

Blue-weed. Echium vulgare. Roadsides. June 9.

Hedge Bindweed. Bracted Bindweed. Convolvulus sepium. Nashua River bank. June 25.

Bindweed. Convolvulus arvensis. Ditches. August I.

Dodder. Love Vine. Cuscuta Gronovii. Roadsides. Quasoponagon meadows. August 8.

Bittersweet. Solanum Dulcamara. Brooks and river banks. June 4. Common Nightshade. Solanum nigrum. Waste places. August I 6.

Common Stramonium. Thorn Apple. Datura Stramonium. Waste places. August 16 .

Purple Thorn Apple. Datura Tatula. Waste places. August I 6.

Common Mullein. Verbascum Thapsus. Roadsides. July I.

Moth Mullein. Verbascum Blattaria. Roadsides. July.

Butter and Eggs. Ramstead. Linaria vulgaris. Roadsides. June 27 .

Toadflax. Linaria Canadensis. Roadsides. August ro.

Turtle-head. Snake-head. Chelone glabra. Quasoponagon meadows. August Io.

Monkey-Flower. Mimulus ringens. Meadows. July 20.

False Pimpernel. Ilysanthes riparia. Nashua River bank. August 30.

Water Speedwell. Veronica Americana. Brooks. June I3.

Marsh Speedwell. Veronica scutellata. Brooksides. June 4.

Thyme-Leaved Speedwell. Veronica serpyllifolia. Roadsides. May ig.

Downy False Foxglove. Gerardia flava. Black Pond. August 2 I. Smooth False Foxglove. Gerardia quercifolia. Oak Grove. July 25.

Purple Gerardia. Gerardia purpurea. Long Hill. Roadsides. August 2.

Gerardia pedicularia. Dry places. July 22.

Scarlet Painted-Cup. Castilleia coccinea. Chicopee Row. May 20.

Wood Betony. Pedicularis Canadensis. Meadow. May 7.

Cow-IVheat. Melampyrum Americanum. Woods. June 27.

American Squaw-Root. Cancer-Root. Conopholis Americana. Woods and roadsides. May 18. Rare. 
One-Flowered Cancer-Root. Naked Broom-Rape. Aphyllon uniflorum. Woods and roadsides. June $\mathrm{r}$.

Greater Bladderwort. Utricularia vulgaris. Shattuck's intervale brook. June 20.

Smaller Bladderwort. Utricularia minor. Brooks by roadsides. June $2 \mathrm{I}$.

White Vervain. Verbena urticaefolia. Roadsides and waste places. July 7 .

Blue Vervain. Verbena hastata. River banks. August r.

Bastard Pennyroyal. Trichostema dichotomum. Fields. August 6.

Spearmint. Mentha viridis. James Brook. July I3.

Peppermint. Mentha piperita. Brooks. August I6.

Wild Mint. Mentha Canadensis. Meadows. May ı。.

Whorled Mint. Mentha sativa. Meadows. August 30.

Vater Horehound. Lycopus Virginicus. Moist places. August.

Basil. Mountain Mint. Pycnanthemum muticum. August 2.

Oswego Tea. Bee-Balm. Monarda didyma. Chicopee Row. July 20.

Catnip (Catmint). Nepeta Cataria. Near houses. July 4.

Gill-over-the-Ground. Nepeta Glechoma. Near houses. May I.

Scutellaria integrifolia. Meadows. July I 7 .

Mad-Dog Skullcap. Scutellaria lateriflora. Meadows. July 9.

Scutellaria galericulata. Meadows. June ro.

Common Motherwort. Leonurus Cardiaca. IVaste places, near houses. June 16 .

Heal-All. Brunella vulgaris. Roadsides. June ro.

Common Hemp-Nettle. Galeopsis Tetrahit. Waste places. August $x$.

Common Plaintain. Plantago major. Roadsides. June 26.

English Plantain. Plantago lanceolata. Roadsides. June 28.

Knawel. Scleranthus annuus. Waste places. June 25 .

Red Amaranth. Amarantus paniculatus. Waste places. August 2.

Pigweed. Green Amaranth. Amarantus retroflexus. Fields and waste places. August 2 .

Tumble-IVeed. Amarantus albus. Fields. August $\mathbf{x}$.

Pigweed. Lamb's-Quarters. Chenopodium album. Waste places. July I.

Garget. Common Poke. Scoke. Phytolacca decandra. Low ground. July 7 . 
Dock. Patience. Rumex patentia. Fields and waste places. May $\mathbf{1} 6$.

Great Water-Dock. Rumex Britannica. Meadows. August I.

Curled Dock. Rumex crispus. Waste places. May 30.

Bitter Dock. Rumex obtusifolius. Waste places. June 9.

Sheep Sorrel. Rumex Acetosella. Fields and waste places. May I6.

Knotweed. Polygonum aviculare. Waste places. July Io.

Polygonum amphibium. Mud. July 30.

Lady's Thumb. Polygonum Persicaria. Damp waste places. July I.

Common Smartweed. Water-Pepper. Polygonum Hydropiper. Wet places. July i 5 .

Halberd-Leaved Tear-Thumb. Polygonium arifolium. Low woods. August 10 .

Arrow-Leaved Tear-Thumb. Polygonum sagittatum. Low woods. June 12 .

Wild Ginger. Asarabacca. Asarum Canadense. Rocky Hill. May 5.

Spice-bush. Benjamin-bush. Lindera Benzoin. North End. March 30.

Bastard Toad Flax. Comandra umbellata. North End. May 29.

Cypress. Spurge. Euphorbia Cyparissias. Roadsides and waste places. July 26.

Hop. Humulus Lupulus. Fields and roadsides. May.

Wood-Nettle. Laportea Canadensis. Black Pond. July I.

Sweet Fern. Myrica asplenifolia. Rockwood's pasture. May I 2.

Wild Hazel-Nut. Corylus Americana. Hedges and roadsides.

March 23.

Beaked Hazel-Nut. Corylus rostrata. Our orchard. Rare. March 23.

Hornwort. Ceratophyllum demersum. Wrangling Brook. Nashua River. August 1 .

Eel-Grass. Tape-Grass. Vallisneria spiralis. Nashua River. August $\mathbf{r}$.

Coral-Root. Orchid. Corallorhiza innata. Black Pond. May 30.

Coral-Root. Orchid. Corallorhiza multiflora. Our woods. August 7 .

Ladies' Tresses. Orchid. Spiranthes Romanzoffiana. Black Pond. August I.

Ladies' 'Tresses. Spiranthes cernua. Fields. August 20.

Ladies' Tresses. Spiranthes gracilis. Duck Swamp. July 23. 
Rattlesnake-Plantain. Orchid. Goodyera repens. Black Pond. July $\mathbf{~} 0$.

Goodyera pubescens. Duck Pond. July 23.

Orchid. Arethusa bulbosa. Plains. Rare. June 17 .

Orchid. Callopogon pulchellus. Kezar's Brook meadow. June i 7 .

Orchid. Pogonia ophioglossoides. Kezar's Brook meadow. June i 7.

Showy Orchis. Orchis spectabilis. Plains. Rare. May 2 I.

Green Orchis. Habenaria virescens. Roarsides. July 3.

Orchid. Habenaria dilatata. Duck Swamp. June 16.

Habenaria blephariglottis. July 30.

Ragged Fringed-Orchis. Habenaria lacera. Long Hill. July 30.

Purple Fringed-Orchis. Habenaria psycodes. Road across

Kezar's Brook swamp. July 30.

Habenaria fimbriata. July 30.

Common Lady's Slipper. Stemless Lady's Slipper. MoccasonFlower. Orchid. Cypripedium acaule. Pine woods. May 20.

Smaller Yellow Lady's Slipper. Cypripedium parviflorum. Woods on Nashua bank. Rare. May to.

Larger Yellow Lady's Slipper. Cypripedium pubescens. Rare. River bank. May 27.

Showy Lady's Slipper. Cypripedium spectabile. Very rare. July I.

Larger Blue Flag. Iris versicolor. Quasoponagon meadows. June 2.

Slender Blue Flag. Iris prismatica. Meadows. Rare. June r.

Blue-Eyed Grass. Sisyrinchium angustifolium. Fields and roadsides. June $\mathbf{I}$.

Yellow-Star Grass. Hypoxis erecta. Fields. June io.

Carrion-flower. Smilax herbaceae. Roadsides. June I 2.

Common Greenbrier. Smilax rotundifolia. Woods. June 20.

Smaller Solomon's Seal. Polygonatum biflorum. Our woods. May 14.

Great Solomon's Seal. Polygonatum giganteum. Woods and meadows. June 3 .

False Solomon's Seal. False Spikenard. Smilacina racemosa. Our woods. June 3 .

False Solomon's Seal. Smilacena trifolia. Our woods. May 27.

Smilacena stellata. Our woods. May 28.

Clintonia borealis. Our woods. May 20.

Oakesia sessilifolia. Roadsides. May r.

Uvularia perfoliata. Damp roadsides. May ı o.

Dog's-tooth Violet. Erythronium Americanum. By Nashua River. April 25. 
Wild Orange Red Lily. Wood Lily. Lilium Philadelphicum. Elm Avenue. July 5.

Turk's-Cap Lily. Lilium superbum. Escaped. July 28.

Wild Yellow Lily. Meadow Lily. Lilium Canadense. Quasoponagon Meadows. July 3 .

Tiger Lily. Lilium tigrinum. Waste places. July I.

Indian Cucumber-Root. Medeola Virginiana. Our woods. June 14.

Purple Trillium. Birthroot. Trillium erectum. Townsend road. Rare. May $\mathbf{2}$.

Nodding Trillium. Trillium cernuum. Old road. May ro.

Painted Trillium. Trillium erythrocarpum. Rare. Our woods. May 10.

American White Hellebore. Indian Poke. Veratrum viride. Roadsides. June I.

Pickerel-Weed. Pontederia cordata. Quasoponagon meadows. July 7 .

Common Spiderwort. Tradescantia Virginica. Long Hill. Escaped. June i 9 .

Common Soft Rush. Juncus effusus. Meadow. August I.

Common Cat-Tail. Typha latifolia. Meadows. Broad Meadow. June 20 .

Bur-Reed. Sparganium eurycarpum. Low land. May 20.

Jack-in-the-Pulpit. Indian Turnip. Arisaema triphyllum. Meadows. May I2.

Arrow Arum. Peltandra undulata. Wrangling Brook. June r6. Water Arum. WVild Calla. Calla palustris. Our woods. May 26.

Skunk Cabbage. Symplocarpus foetidus. Meadow. Formerly blossomed in February, of late years in September.

Siveet Flag. Calamus. Acorus Calamus. Quasoponagon meadows. June Io.

Duckweed. Duck's-Meat. Lemna minor. Ditches on Broad Meadow. July I.

Water Plantain. Alisma Plantago. Quasoponagon meadows. July 20.

Arrow-head. Sagittaria variabilis. Brooks. July 15 .

Sagittaria heterophylla. Meadows. August I.

Pipewort. Eriocaulon septangulare. Meadows. July ı.

Pennsylvania Sedge. Carex Pennsylvanica. Meadows. April 5.

Many other Sedges.

Witch. Couch. Quick Grass. Agropyrum repens.

Many other Grasses. 
TREES.

Woodman, spare that tree !

Touch not a single bough!

In youth it sheltered me,

And I 'll protect it now.

'T was my forefather's hand

That placed it near his cot;

There, woodman, let it stand,

Thy axe shall harm it not.

That old familiar tree,

Whose glory and renown

Are spread o'er land and sea -

And wouldst thou hew it down?

Woodman, forbear thy stroke!

Cut not its earth-bound ties;

Oh, spare that aget oak,

Now towering to the skies!

When but an idle boy,

I sought its grateful shade;

In all their gushing joy

Here, too, my sisters played.

My mother kissed me here;

My father pressed my hand -

Forgive this foolish tear

But let that old oak stand.

My beart-strings round thee cling,

Close as thy bark, old friend I

Here shall the wild-bird sing,

And still thy branches bend.

Old tree! the storm still brave!

And, woodman, leave the spot;

While I've a hand to save,

Thy axe shall harm it not.

MORRIS.

Tulip Tree. Yellow Poplar. Liriodendron Tulipifera. Cultivated. Mr. Amory A. Lawrence's. May r.

Linden. Basswood. Lime Tree. Tilia Americana. Native. Roadsides. May I. 
Ailanthus. Tree of Heaven. Ailanthus glandulosa. Cultivated. Mr. G. Shattuck's. June I.

Holly. Ilex opaca. Cultivated. Mr. Huebner's. June I.

Horse Chestnut. Aesculus Hippocastanum. Has become native. Roadsides. Main Street. May 20.

Striped Maple. Moosewood. Acer Pennsylvanicum. Roadsides. Native. June.

Sugar Maple. Rock Maple. Acer saccharum. Long Hill. Main Street. Native. April 2.

Silver Maple. Soft Maple. White Maple. Acer saccharinum. River bank. Red Bridge. Native. April I.

Red Maple. Sivamp Maple. Soft Maple. Acer rubrum. Main Street. Native. April.

Norway Maple. Acer platanoides. Long Hill. Cultivated. April.

Sycamore Maple. Acer pseudoplatanus. Cultivated. May.

Box Elder. Ash-Leaved Maple. Acer negundo. Cultivated. Groton School. April.

Staghorn Sumach. Rhus typhina. Rocky hills. Native. June ro. Smooth Sumach. Rhus glabra. Roadsides. June 20.

Dwarf Sumach. Rhus capallina. Roadsides. July 10.

Poison Sumach. Poison Dogwood. Rhus venenata. Our woods. June 1 .

Poison Ivy. Poison Oak. Rhus toxicodendron. Main Street. River banks. Roadsides. The leaves of this plant closely resemble the Woodbine. There need be no confusion if the following rhyme js remembered. "Leaves three quickly flee. Berries red, have no dread. Berries white, poisonous sight." W. H. Gibson. June.

Round-Leaved Cornel or Dogwood. Cornus circinata. Elm Avenue. June 2 .

Silky Cornel. Kinnikinnik. Cornus sericea. Frog Pond. June 5. Red-osier. Dogwood. Cornus stolonifera. Elm Avenue. May 30.

Panicled Cornel. Cornus paniculata. Long Hill. June I.

Alternate-Leaved Dogwood. Cornus alternifolia. Elm Avenue. May 30.

Flowering Dogwood. Cornus florida. Lower Ayer road. May. Common Elder. Sambucus Canadensis. Red Bridge. June I. Hobble Bush. American Wayfaring Tree. Viburnum lantanoides. Chicopee Row. Native. May 1 o. 
Cranberry-Tree. Viburnum Opulus. Native. Mr. John Parker's yard and roadside by Mrs. Amasa Hartwell's. June Io.

Snow-Ball Tree. Guelder-Rose. Cultivated state of IVild Cranberry-Tree. Cyme turned into sterile flowers. June I.

Arrow-IVood. Dockmackie. Viburnum acerifolium. By grove. June 9 .

Arrow-Wood. Viburnum dentatum. Long Hill. June I 2.

Withe-Rod. Viburnum cassinoides. Elm Avenue. June 7 .

Sweet Viburnum. Sheep-Berry. Viburnum Lentago. Elm Avenue. May 20.

Black Haw. Stag-Bush. Viburnum prunifolium. Our woods. May.

Smoke-Tree. Cotinus cotinoides. Cultivated. Miss Warren's. June.

Locust Acacia. Yellow Locust. Robinia Pseudacacia. Cultivated. June.

Locust. Clammy Locust. Robinia viscosa. Cultivated. June.

Bristly Locust. Rose Acacia. Robinia hispida. Escaped from cultivation. May.

Honey Locust. Gladitsia triacanthos. Court Street. Chicopee Row. Has become naturalized. May.

Kentucky Coffee-Tree. Gymnocladus dioicus. Cultivated. June.

IVild Red Cherry. Bird Cherry. Prunus Pennsylvanica. Roadsides. May.

Canada Plum. Red Plum. Prunus nigra. Native. Nashua River bank. May.

IVild Cherry. Choke Cherry. Prunus Virginiana. Roadsides. May.

Black Cherry. Prunus serotina. Roadsides. May.

Crab-Apple. Pyrus coronaria. Cultivated. May.

Mountain Ash. Pyrus Americana. Cultivated. Long Hill. May.

Mountain Laurel. Calico Bush. Spoon-IVood. Kalmia latifolia. Mr. F. Lawrence Blood's pasture. June io.

Cockspur-Thorn. Crataegus Crus-galli. Roadsides. May.

White Thorn. Scarlet Haw. Crataegus coccinea. Roadsides. M.

Black Thorn. Crataegus tomentosa. Roadsides. June.

Scarlet Haw. Hawthorn. Crataegus mollis. Roadsides. May. 
Shad-Bush. June Berry. Service Berry. Amelanchier Canadensis. River bank. April.

Witch Hazel. Hamamelis Virginiana. Our grove. Cctober. Rhododendron. Rhododendron maximum. Cultivated. May. White Ash. Fraxinus Americana. Native. Roadsides. May. Red Ash. Fraxinus Pennsylvanica. Native. Roadsides. May. Black Ash. Fraxinus nigra. Native. Roadsides. May. Catalpa. Indian Bean. Catalpa catalpa. Cultivated. Mr. Amory A. Lawrence's field. June.

Sassafras. Sassafras sassafras. Our grove. Native. May.

White Elm. Ulmus Americana. Native. Main Street. March. Slippery Elm. Ulmus pubescens. Main Street. Dr. Samuel A. Green's yard. Rare. March.

English Elm. Ulmus campestris. Main Street. Mr. Frank L. Blood's. Cultivated. March.

Hackberry. Celtis occidentalis. Our woods. Native. May.

White Mulberry. Morris alba. Our orchard. Cultivated. May. Sycamore. Buttonwood. Platanus occidentalis. Chicopee Row. Native. May.

Black Walnut. Juglans nigra. Hollis Street. Native. May. Butternut. White Walnut. Juglans cinerea. Our orchard. Native. May.

Bitternut. Swamp Hickory. Hicoria minima. Rocky Hill. Native. May.

Shagbark. Shell Bark Hickory. Hicoria ovata. Native. Elm Avenue, Chicopee Row and other roadsides. May.

Pignut. Hicoria porcina. Rockwood's pasture. Native. May.

White Birch. Gray Birch. Betula populifolia. Roadsides. Common. April.

Paper Birch. White Birch. Canoe Birch. Betula papyrifera. Roadsides. Not very common. April.

Red Birch. River Birch. Betula nigra. Cultivated. Mr. L. Brooks. March.

Yellow Birch. Betula lutea. Our woods. Native. April.

Sweet Birch. Black Birch. Betula lenta. Our woods. April.

Alder. Alnus glutinosa. Conmon. Roadsides. March.

Hop Hornbeam. Iron Wood. Ostrya Virginica. Dry banks. April.

Hornbeam Blue Beech. Carpinus Caroliniana. River bank. April. White Oak. Quercus alba. Roadsides. Native. May. 
Post Oak. Quercus minor. Roadsides. Native. May.

Burr-Oak. Massy-Cup Oak. Quercus macrocarpa. May. Rocky Hill. Native.

Chestnut Oak. Quercus prinus. Woods. Native. May.

Sivamp White Oak. Quercus platanoides. Woods. Native. May.

Red Oak. Quercus rubra. Roadsides. Native. May.

Scarlet Oak. Quercus coccinea. Roadsides. Native. May.

Black or Yellow Oak. Quercus volutina. Roadsides. Native May.

Pin Oak. Quercus palustris. Swamps. Native. May.

Bear Oak. Scrub Oak. Quercus ilicifolia. Rocky Hill. Native. May.

Beech. Fagus atropunicea. Roadsides. Native. April.

Purple or Copper Beech. Cultivated. April.

Chestnut. Castanea dentata. Mr. L. Brooks. Chestnut Hills. Native. June.

Black Willow. Salix nigra. Native. Roadsides. March.

Bebb Willow. Salix bebbiana. Native. Roadsides. March.'

Glaucous Willow. Pussy Willow. Salix discolor. Roadsides. Native. March.

White Willow. Yellow Willow. Salix alba. Meadows. Cultivated. March.

Crack Willow. Salix fragilis. Cultivated. Roadsides. March.

Spanish Willow. Cultivated.

Weeping Willow. Salix Babylonica. Cultivated.

Aspen. Quaking Asp. Populus tremuloides. April. Roadsides. Native.

Large-Toothed Aspen. Populus grandidentata. Native. Roadsides. April.

Swamp Cottonwood. Populus heterophylla. Our woods. Native. March.

Balm-of-Gilead. Tacamahac. Populus balsamifera candicans. Native. March.

Cottonwood. Populus deltoides. Native. March.

White Poplar. Populus alba. Cultivated. April.

Lombardy Poplar. Populus nigra italica. Mr. F. L. Blood's yard. Cultivated. April. 
GYMNOSPERMS. THE PINES.

White Pine. Soft Pine. Pinus Strobus. Common. Native. June.

Red Pine. Norway Pine. Canadian Pine. Pinus resinosa. Native. Mr. James Lawrence's woods. June.

Pitch Pine. Hard Pine. Pinus rigida. Common. Native. April.

Austrian Pine. Pinus laricia Austriaca. Cultivated.

Scotch Pine. Pinus sylvestris. Cultivated.

Gray or Northern Scrub Pine. Pinus divaricata. Native.

White Spruce. Picea rubens. Woods. Native. April.

Black Spruce. Picea mariana. IVoods. Native. May.

Norway Spruce. Picea excelsa. Cultivated. Roadsides. June.

Hemlock. Tsuga Canadensis. Rockwood's pasture. Native. April.

Larch. Larix laricina. Mr. James Lawrence's woods. Native. May.

European Larch. Larix Europaea. Main Street. Cultivated. May. Balsam Fir. Abies balsamia. Native. Mr. F. D. Lewis's yard May.

Arborvitae. Thuja occidentalis. Cultivated hedges. May.

White Cedar. Cypressus thyoides. Woods. Native. April.

Juniper. Ground Cedar. Juniperus communis. Rockwood's pasture. Native. April.

Red Cedar. Savin. Juniperus Virginiana. Rockwood's pasture. Native. April. 


\section{FAUNA.}

THE Fauna of Groton includes all animal life. We begin with the lowest, the Protozoans, one-celled, minute Amoeba found in all fresh water.

The Porifera Branch is doubtless represented by freshwater Sponges, although I have never found them. The Coelenterata is represented by the fresh-ivater Hydra, very small in all water. Vermes includes Worms, Hair Snakes, Leeches, Earthworms.

Mollusca - Fresh-water Mussels. Mussel beds are found in the Nashua and Squannacook rivers.

Valuable pearls have been found in those in the Squannacook. Many kinds of Pond and Land Snails and Slugs.

The Branch Arthropoda is represented by a great number of species: the Cyclops, a very small water-flea; fresh water Cray-fish, Sow-bugs, Spiders, Mites of many varieties, Centipedes, Millepedes, and Insects.

INSECTS AND THEIR RELATIVES.

There are thousands of species of Insects in Groton, some injurious and some beneficial. Beginning with the lowest order, Thysanura, are the Bristle Tails; Silver Moth or Fish Moth, Lepisma saccharina, found in closets eating cloth and paper; also the Spring Tails or Snow Fleas, Achorutes nivicola. Swarms of these may be seen covering the snow after a thaw.

The May-flies are in the Ephemerida Order, several species. The Odonata Order contains the Dragon-flies; thirty species have been identified. The Plecoptera Order contains the Stone-flies, one species. The young are found under stones in brooks. The Isoptera Order contains the Termites, or White Ants; these are not the real ants and are not very common. The Corrodentia Order includes Psocids and Book-lice; the latter are the tiny creatures that scurry across the pages of old books. The Mallophaga Order contains 
Bird-lice of many kinds. The Euplexoptera Order - Earwigs, rare.

The Orthoptera Order contains the Running Orthoptera, Blattidae, or Cockroaches, several kinds; the Walking Orthoptera, Phasmidae, Walking Sticks, one kind; the Jumping Orthoptera, Acrididae, or Short-horned Grasshoppers, several kinds; Locustidae, Long-horned Grasshoppers, several kinds; Gryllidae, Crickets, several kinds. The Physopoda Order contains Thrips, one kind. The Hemiptera Order contains Bugs, Lice, Aphids, and others - twenty-five families of Bugs, many species; one family of Lice, and nine of Aphids. The Neuroptera Order contains three families, the Dobsons, the Aphis Lion, the Ant Lion.

The Mecoptera Order contains the Scorpion-flies and others. The Trichoptera Order contains the Caddice-flies. They live in brooks, when immature, decorate their houses with sticks, snail shells, pebbles, etc., living inside and dragging them along with them.

The Lepidoptera Order contains the Moths, Skippers, and Butterflies, a beautiful and interesting order. There are thirty-four families of Moths, including many hundred species; two families of Skippers, several species; four families of Butterflies, including about one hundred species.

The Diptera Order, the Flies, contains thirty families and many species. The Coleoptera Order contains the Beetles, a handsome and interesting order, eighty families and eleven hundred species. The Hymenoptera Order contains the Bees, two families; Wasps, eight families; and two families of Ants, also Saw-flies, Horn-tails, Gall-flies, Ichneumon-flies, and others. This is a very interesting order. The Ichneumon-flies attract considerable attention, especially the large Thalessa lunator. It measures ten inches from tip of antennae to the tip of its ovipositor. These are the insects which are often seen on the maple tree in front of Mr. Torrey's store. It is a parasite of a Horntail which places its eggs inside the trunks of trees; the Ichneumon-fly drills a hole into the tree near these eggs; the young of this insect eats the larva of the Horntail. 


\section{THE VERTEBRATA.}

The highest branch of Animals is the Vertebrata. This includes the following classes:

Fish - Pisces; Eels - Anquilla; Salamanders, Frogs, Toads, Turtles, - Reptilia; Birds - Aves; Mammals Mammalia. This last is the highest class, and includes the following Orders; Insectivora, or Insect-Eating Mammals; Chiroptera, or Bats; Rodentia, or Gnawing Mammals; Ungulata, or Hoofed Mammals; Carnivora, or Flesh-Eating Mammals; Primates, or Man Family.

\section{FISH.}

Salmon. Salmo salar. The Landlocked Salmon is very rare in Massachusetts, but has been caught in Groton.

Great Lake Trout. Salmon Trout. Salvelinus namaycush. Baddacook Pond has been stocked with this fish.

Brook or Speckled Trout. Salvelinus fontinalis. Unquetenassett Brook.

Pickerel. Esox reticulatus. All ponds.

Mud Minnow. Umbra limi. Soapstone Quarry by Mr. Fred. Howe Torrey.

Common Sucker. Catostomus teres. Quasoponagon meadows. Cow Pond. Brooks and meadows.

Chub Sucker. Erimyson sucetta. Mr. Fred. H. Torrey reports it at Barldacook.

Chub. Roach. Semotilus bullaris. Rivers and ponds.

Dace. Cousin Trout. Semotilus atromaculatus. Found in brooks.

Black-Nosed Minnow. Rhinichtys atronasus. Nashua River.

Long-Nosed Minnow. Rhinichtys cataractae. Nashua River.

Common Shiner. Redfin. Notropis cornutus. All ponds and rivers: Yellow Perch. Perca fluviatilis. All ponds and rivers.

Black Bass. Micropterus dolomieu. Southern fish transplanted. Rivers.

Sunfish. Bream. Pumpkin Seed. Lepomis gibbosus. All ponds. Hornpout. Amiurus rebulosiss. All ponds.

Eel. Anquilla anquilla. All ponds and rivers. 


\section{REPTILES, ETC.}

Snapping Turtle. Chelydra serpentina. This is found in ponds and rivers and grows to be very old, large, and fierce. Some have weighed forty pounds and could easily carry a person on their backs.

Wood Turtle. Chelopus insculptus. Rather common. Found in woods.

Musk Turtle. Aromochelys odoratus. This is a rare turtle. Found in ditches in the woods.

Painted Turtle. Chrysemys picta. This is a common turtle, very pretty. Found in ponds and ditches.

Spotted Turtle. Chelopus guttatus. Quite common in ditches. Prettily marked.

Common Box Turtle. Cistudo Carolina. This is a very rare turtle. Found in the woods. Our woods.

Common Lizard. Sceloporus undulatus. I do not remember to have found a lizard, but probably have done so and confused it with the Salamanders, which it resembles. Mr. Fred H. Torrey reports it from Sandy Pond.

Rattlesnake. Crotalus horridus. This snake inhabits high, re mote places and is reported from time to time from the Throne, Snake Hill, etc.

Copperhead. Agkistrodon contortrix. I have never seen this snake. It doubtless has been found here at some time.

Milk Snake. Spotted Adder. Ophibolus doliatus triangulus. Rare.

Water Snake. Tropianotus sipedon. This is a fierce, common snake, ugly looking. Found in ponds and ditches.

Striped Snake. Garter Snake. Eutainia sirtalis. Common snake. Found everywhere.

Ribbon Snake. Eutainia saurita. Mr. Fred. H. Torrey reports this as found in fields.

Black Snake. Racer. Bascanion constrictor. This is the handsome black snake found everywhere. In the spring many may be seen coiled up together in rocky places. They also run from branch to branch among the trees, overhead.

Grass Snake. Leiopeltis vernalis. Found everywhere in the grass. Handsome.

Ground Snake. Carphophiops amoenus. Found everywhere. 
Ring-Necked Snake. Diadophis punctatus. In grass. Rare.

Bull Frog. Rana catesbiana. Largest. Deep resounding voice. Rivers and ponds.

Green Frog. Rana clamata. Found in ditches.

Leopard Frog. Rana virescens. In ponds. First to be heard in the spring. Cluck.

IVood Frog. Rana sylvatica. Common in woods.

Northern Frog. Rana septentrionalis. Common in ditches.

Pickerel Frog. Rana palustris. Found in ponds and ditches.

Cricket Frog. Acris gryllus. Little frog found in ponds and ditches.

Pickering's Tree Frog. Spring Peepers. Hyla Pickeringii. Found in wet places. Shrill, high voices. In the autumn lives in trees.

Common Tree Toad. Hyla versicolor. Common in ponds in spring and trees in summer. Rattles.

Common Toad. Bufo lentiginosus. Very common everywhere. One of the first spring singers.

Newt. Diemyctylus viridescens. Found in ponds and ditches in the spring. Green with red dots. Bright red in the fall. Found under stones.

Striped Salamander. Spelerpes bilineatus. Damp places.

Red Salamander. Spelerpes ruber. Damp places.

Red-Backed Salamander. Plethodon erythronotus. Common in damp places.

Spotted Salamander. Amblystoma punctatum. Largest. Common under stones.

These reptiles should not be killed, as they are harmless, useful, insect-eating animals. 
- BIRDS - AVES.

What ThE BiRdS SAY.

When light of morning is softly appearing, What are the voices we often are hearing, As we lie half dreaming and half awake, Listening to sounds the sweet birds make?

The Whippoorwill first breaks the still quiet hour, "Whippoorwill! Whippoorwill!" His voice has great power, Repeating it over and over again,

Now quickly, now slowly, a mournful refrain.

The Goldfinch breaks in with a "Swē-ē-ēt, swē-ē-ēt,"

Then with beautiful notes makes his sweet song complete.

The Chippy now comes with his "Chē-chē-chē-chē!"

Not many birds are as early as he.

"Phoe'be! Phoebe'!" Hear the imperative call.

"Come, you don't see me," is heard above all.

Now the Song Sparrow is singing alone,

Sweetly and clearly a musical tone.

Soon hear "Chebeck," 't is the Flycatcher small,

Crying "Chebeck" in a querulous call.

"Witchety! witchety! witchety! witch!"

Comes from the Yellow Throat down by the ditch.

"Very early! Very early! Wake up! Dilatory!"

Says Robin Redbreast in all his glory.

Joining with him is the Oriole heard;

Questions he 's asking of each little bird.

What voice is this we soon hear so sweet?

Broken, ' $t$ is generally not half complete,

When a coarse sudden "Mew!" banishes doubt,

For the Catbird sings sweetly, but never without

Mixing in suddenly here and there

The cry of the cat in every air.

Melodious the solo which now arises,

Tuneful, with many and sudden surprises.

'T is the bright Bobolink, that merry fellow,

With his black vest and coat tinged with yellow.

He flings his rich notes into the air,

And warbles away with never a care.

'T is five o'clock! The sun rises! Hush!

List to the wonderful song of the Thrush!

High, clear, flutelike, smooth, descending

Purc, sweet and truc to the very ending. 
Over and over with varying trills,

All through your soul and being thrills.

At last ' $t$ is silent! Then there pours forth again

Such a wonderful chorus as e'er heard by men;

Each one singing his own refrain,

Then all together and over again.

Thus joyfully through the long summer morn

In the air the grand chorus of birdsong is born.

Groton is an interesting and satisfactory hunting ground for bird lovers; as it is situated in the Transition Zone, the Northern as well as the Southern birds are liable to be seen. Naturally a town with many trees and shrubs is well populated with birds, as they find their food as well as live among them. I have had walks with students from all over Massachusetts, members of many outing clubs, and they all agree that Groton is an ideal place for bird study. On a rainy day, May 9, 1900, nineteen different species of Warblers came within view from my window, and within one hour thirty-four species of birds were identified. Those living on Main Street also have a good chance for studying them. During the months of May, June, and July of 1909, I heard from my bea in the Groton Hospital thirty-six different species. Mr. Ralph Hoffmann, a well-known ornithologist, said that the Groton Audubon Society was the liveliest and knew the most bird lore of any society in the State.

The following is a list giving date of arrival and departure of the Birds:

Pied-Billed Grebe. Dabchick. Hell Diver. Water Witch. Podilymbus podiceps. This is often wrongly called a Dipper Duck; it is not a duck. Rare migrant, April i to November I. Doubtless breeds here occasionally, as I saw them in the Nashua River, July 30, I90I.

Loon. Great Northern Diver. Gavia imber. About twenty-five years ago one was killed on the Squannacook River, is mounted and in the possession of Mrs. Walter Tarbell. There is also one in the Public Library killed by Mr. William Robinson. Very rare winter visitant.

Little Auk. Ice Bird. Dovekie. Sea Dove. Alle alle. Accidental visitant. One killed over thirty years ago, on the Squannacook River. 
American Merganser. Goosander. Sheldrake. Merganser amer-

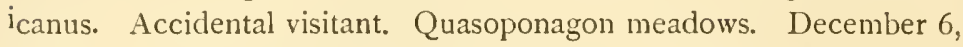
1906.

Mallard. Anas boschas. Transient visitant. Quasoponagon meadows. April and October.

Black Duck. Dusky Duck. Anas obscura. Quite common summer resident. Quasoponagon meadows. March to December.

Wood Duck. Aix sponsa. Formerly a common permanent resident. Quasoponagon meadows.

Bufflehead. Butter-ball. Spirit Duck. Charitonetta albeola. Transient visitant. Baddacook Pond. November.

Canada Goose. Branta Canadensis. Common migrant. March and December.

American Bittern. Stake Driver. Thunder Pumper. Narsh Hen. Botaurus lentiginosus. Not common. Summer resident, April i 4 to November. Almost every evening in the summer this bird may be heard "booming" in the Quasoponagon meadows.

Least Bittern. Ardetta exilis. Not common summer resident, Nashua River banks. May 14 to August 20.

Great Blue Heron. Blue Crane. Ardea herodias. Although this is a Heron, it is often called a Crane. Summer resident. Nashua River banks. March to November.

Little Green Heron. Poke. Ardea virescens. Summer resident. May I to September. Nashua River banks.

Black-Crowned Night Heron. Quawk. Nycticorax nycticorax naevius. Common summer resident. April 20 to September. Occasionally in winter. Nashua River banks.

American Woodcock. Philohela minor. Summer resident. Formerly common. Quasoponagon meadows. March 20 to November.

Wilson's Snipe. English Snipe. Gallinago delicata. Quasoponagon meadows. Transient visitant, May $\mathbf{I}$ and October.

Least Sandpiper. Meadow Oxeye. Peep. Tringa minutilla. Quasoponagon meadows. Transient visitant, May to August.

Greater Yellow-Legs. Totanus melanoleucus. Accidental visitant. Said to have been seen once in Groton in Miss Sears's eddy several years ago.

Solitary Sandpiper. Totanus solitarius. Quasoponagon meadows. Transient visitant, May and October.

Spotted Sandpiper. Actitis macularia. Quasoponagon meadows. Common summer resident, April 20 to September. 
Bob-White. Quail. Colinus Virginianus. Quasoponagon meadows. Once. common, now a rare permanent resident.

Ruffled Grouse. Partridge. Bonasa umbellus. Once a common permanent resident, now rare. Woods.

Pheasant. English Pheasant. Phasianus colchicus. Also RingNecked Pheasant. Phasianus torquatıs. Introduced permanent residents.

Passenger Pigeon. Ectopistes migratorius. Once a common transient visitant. Not been seen for many years.

Mourning Dove. Zenaidura macroura. Summer resident. Often mistaken for the Wild or Passenger Pigeon. Quite a large flock seen in the summer of rgos.

Marsh Hawk. Harrier. Circus Hudsonius. Common transient visitant, a few residents, March 12 to November. Quasoponagon meadows.

Sharp-Shinned Hawk. Accipiter velox. Common transient visitant, April 20 to November. This is one of the real Hen Hawks. Quasoponagon meadows.

Cooper's Hawk. Accipiter cooperi. Permanent resident. A large Hen Hawk. Quasoponagon meadows.

Hen Hawk. Red-Tailed Hawk. Buteo borealis. Summer resident, April to November. Our fields.

Red-Shouldered Hawk. Hen Hawk. Buteo lineatus. These two are not really Hen Hawks, but are often called so. Permanent residents. Our fields.

Broad-Winged Hawk. Buteo latissimus. Rare transient visitant. Long Hill.

American Rough-Legged Hawk. Archibuteo lagopus sanctijohannus. Rare transient visitant. Long Hill.

Golden Eagle. Aquila chrysaetos. Accidental visitant. This Eagle has doubtless visited Groton. In September and October of I goI, I saw two birds, either the young Bald Eagle or the Golden Eagle. The only difference being in the feathering of the legs, they were not near enough to be distinguished. A Golden Eagle was killed in Townsend in that year, so it seems as if these might have been of the same species.

Bald Eagle. Haliaetus leucocephalus. Accidental visitant. I have seen these eagles quite often. One lighted once in the top of the elm in our yard. August 27, 1903, and May 6, I901, are two records I find.

Pigeon Hawk. Falco columbarius. Common transient visitant, April to October. Quasoponagon meadows. 
American Sparrow Hawk. Falco sparverius. Summer resident; also in January and November. Our fields.

American Osprey. Fish Hawk. Pandion haliaeetus carolinensis. Transient visitant; often a summer resident, April Io to September. Often seen fishing over the ponds and rivers.

Long-Eared Owl. Asio wilsonianus. Rare permanent resident. Mr. James Lawrence's woods.

Saw-Whet Owl. Acadian Owl. Nyctala acadica. Winter visitant. Mr. James Lawrence's woods.

Screech Owl. Megascops asio. Common permanent resident. Old trees everywhere.

Great Horned Owl. Bubo virginianus. Quite common permanent resident. Woods by Nashua River.

American Hawk Owl. Surnia ulula caparoch. Rare. Accidental visitant. December 20, I 904 .

Yellow-Billed Cuckoo. Coccyzus americanus. Common summer resident, May 8 to August. Thickets.

Black-Billed Cuckoo. Coccyzus erythrophthalmus. Common summer resident, May 7 to September. Thickets.

Belted Kingfisher. Ceryle alcyon. Common summer resident, April 20 to October. Nashua River. Ponds and streams.

Hairy Woodpecker. Dryobates villosus. Rare permanent resident. Balm of Gilead trees near Red Bridge.

Downy Woodpecker. Dryobates pubescens. Common permanent resident. Holes in birch trees, etc.

Yellow-Bellied Sapsucker. Sphyrapicus varius. Transient visitant, April and October. Our elm.

Pileated Woodpecker. Ceophloeus pileatus. Extremely rare. Seen by Mr. Frank D. Lewis on Chicopee Row, May, 1903. Also one by Mr. William P. Wharton, near the Red Bridge in rgio. I saw one in June, $\mathbf{r} 905$.

Red-Headed Woodpecker. Melanerpes erythrocephalus. Formerly common, very rare now. October 7 , 1904, I saw one at the foot of Long Hill.

Flicker. High-Hole. Yellow Hammer. Golden-Winged Woodpecker. Colaptes auratus. Common summer resident, March to November. Everywhere. Our largest common woodpecker.

Whip-poor-will. Antrostomus vociferus. Common summer resident, April 2 I to September. Rockwood's pasture.

Nighthawk. Bull-Bat. Chordeiles virginianus. Common summer resident, April 20 to September. 
Chimney Swift. Often called Chimney Swallow. Chaetura pelagica. Common summer resident, April 23 to October. Our chimney.

Ruby-'Throated Humming-Bird. Trochilus colubris. Rather rare summer resident, May 15 to September. Our yard.

Kingbird. Tyrannus tyrannus. Very common summer resident, May 7 to September. Orchard.

Great-Crested Flycatcher. Myiarchus crinitus. Rare summer resident, May 7 to August 30 . Fields near Hazel Grove road.

Phoebe. Sayornis phoebe. Common summer resident, March I 7 to October 3o. Near bridges.

Olive-Sided Flycatcher. Contopus borealis. Transient visitant, May and September. Rare. Our orchard.

Wood Pewee. Contopus virens. Common summer resident, May I 3 to September. IVoods.

Yellow-Bellied Flycatcher. Empidonax flaviventris. Rare transient visitant, May 9 to October 2. Our orchard.

Least Flycatcher. Chebec. Empidonax minimus. Common summer resident, May 7 to September. Orchards.

Horned Lark. Shore Lark. Otocoris alpestris. Rare. Winter visitant. November. Gibbet Hill.

Blue Jay. Cyanocitta cristata. Common resident. Everywhere.

American Crow. Corvus americanus. Common permanent resident. A large "Crow-Roost" is situated on the Reedy Meadow road. Thousands may be seen here during migrations.

Bobolink. Reedbird. Ricebird. Dolichonyx oryzivorus. Common resident in summer, May 7 to September. Long Hill. Fields.

Cowbird. Molothrus ater. Common summer resident, March i6 to October. Pastures.

Red-Winged Blackbird. Agelaius phoeniceus. Common summer resident, March 12 to September. Quasoponagon meadows.

Meadow Lark. Field Lark. Sturnella magna. Common summer resident. Winters often. Long Hill and fields.

Orchard Oriole. Icterus spurius. Rare summer resident. May 17 to September. Our orchard.

Baltimore Oriole. Golden Robin. Hang-Nest. Icterus galbula. Common summer resident, May 7 to September. Elm trees. Main Street.

Rusty Blackbird. Scolecoplagus carolinus. Common transient visitant, April $\mathbf{r}$ and October. Quasoponagon meadows.

Bronzed Grackle. Crow-Blackbird. Quiscalus quiscula aeneus. 
Common summer resident, March I to November. Often winters. Burying ground.

Pine Grosbeak. Pinicola enucleator. Common winter visitant, October 30 to April r I. Everywhere when common.

Purple Finch. Carpodacus purpureus. Common permanent resident. Orchards.

House Sparrow. English Sparrow. Passer domesticus. Not very common permanent resident. Introduced. Hedges on Main Street.

American Crossbill. Red Crossbill. Loxia curvirostra minor. Accidental winter visitant. December. Pine trees.

White-Winged Crossbill. Loxia leucoptera. Rare winter visitant. December. Pines.

Redpoll. Acanthus linaria. Common winter visitant, November to Nay. Birches and alders.

Greater Redpoll. Acanthus linaria rostrata. Rare winter visitant. Seen once at our window.

American Goldfinch. Yellow-Bird. Thistle-Bird. Spinus tristis. Common permanent resident. Feeds on weeds, especially catnip. Our yard.

Pine Siskin. Pine Finch. Spinus pinus. Winter visitant, October to April. Weeds, birches, and alders.

Snowflake. Snow Bunting. Plectrophenax nivalis. Winter visitant, October to March. Flocks in snowstorms. Never in trees.

Vesper Sparrow. Bay-IVinged Bunting. Poocaetes gramineus. Common resident, April i I to October. Fields.

Savanna Sparrow. Ammodramus sandwichensis savanna. Transient visitant, April and October. Fields.

Grasshopper Sparrow. Yellow-Winged Sparrow. Ammodramus savannarum passerinus. Rather common summer resident, May 7 to September. Long Hill, Chicopee Row.

Henslow's Sparrow. Ammodramus henslowii. Summer resident, rather rare, May to September. Long Hill, Peabody Street. Fitch's Bridge. Fields.

White-Crowned Sparrow. Zonotrichia leucophrys. Uncommon transient visitant, May 6 to October I. Quasoponagon meadows.

White-Throated Sparrow. Zonotrichia albicollis. Common transient visitant, rare resiclent in summer, April 9 to November. Quasoponagon meadows.

Tree Sparrow. Winter Chippy. Spizella monticola. Common winter visitant, November to March. In weed-fields, alders, and birches. Everywhere. 
Chipping Sparrow. Spizella socialis. Abundant summer resident everywhere, April 8 to November.

Field Sparrow. Spizella pusilla. Common summer resident, April 14 to November. Fields.

Junco. Snowbird. Junco hyemalis. Common winter visitant, September to April. Bushes by roadsides.

Song Sparrow. Melospiza fasciata. Common summer resident, sometimes winter resident, March Io to November. Everywhere.

Swamp Sparrow. Melospiza georgiana. Summer resident, April i 5 to October. Swamps.

Fox Sparrow. Passerella iliaca. Common transient visitant, March I 3 to November. Roadsides.

Towhee. Chewink. Pipilo erythrophthalmus. Common summer resident, May I to October. Bushes on ground.

Rose-Breasted Grosbeak. Habia ludoviciana. Common summer resident, May 4 to September. Main Street.

Indigo Bird. Passerina cyanea. Common summer resident, May i I to October. Roadsides.

Scarlet Tanager. Piranga erythromelas. May I3 to October. Forests.

Purple Martin. Progne subis. Very rare, once common resident. Last seen Nay 5, I 904. Bird houses.

Cliff Sivallow. Eave Swallow. Petrochelidon lunifrons. Rather rare summer resident, May I to September. Mr. Z. Fitch's barn eaves.

Barn Swallow. Chelidon erythrogaster. Common summer resident, April ig to September. Barns.

Tree Swallow. White-Bellied Sivallow. Tachycineta bicolor. Common summer resident, March 28 to October. In trees and houses.

Bank Sivallow. Clivicola riparia. Common summer resident, May I to September. Nashua River banks.

Cedar Waxwing. Cedar-bird. Ampelis cedrorum. Permanent resident. Common. Orchards.

Northern Shrike. Butcher-Bird. Lanius borealis. Winter visitant, November to March.

Red-Eyed Vireo. Vireo olivaceus. Common everywhere. Summer resident, May 5 to September. Elms everywhere.

Philadelphia Vireo. Vireo philadelphicus. Very rare transient: visitant. Seen once near Blood's lily moat, May 6, I 905.

Warbling Vireo. Vireo gilvus. Common summer resident, May 8 to September. Roadsides. 
Yellow-Throated Vireo. Vireo flavifrons. Common summer resident, May 7 to September. High trees.

Blue-Headed Vireo. Vireo solitarius. Rather rare, transient visitant, April 25 and October. Woods.

White-Eyed Vireo. Vireo Noveboracensis. Rare summer resident, May 5 to September I3. Quasoponagon meadows.

Black and White Warbler. Black and White Creeper. Mniotilta varia. Common summer resident, April I to September. Woods.

Worm-Eating IVarbler. Helmitherus vermivorus. Very rare, accidental visitant. One record. Rockwood's pasture. May 20, I 899 .

Golden-Winged Warbler. Helminthophila chrysoptera. May 9 to September. Rare. Thickets.

Blue-Winged Warbler. Helminthophila pinus. Uncommon transient visitant. Sept. 6, I go4.

Nashville Warbler. Helminthophila ruficapilla. Summer resident, May 5 to October. Pastures. Rather common.

Tennessee Warbler. Helminthophila peregrina. Rare transient visitant. One record, April 26, I 908 .

Parula Warbler. Blue Yellow-Backed Warbler. Compsothlypis americana. Common transient visitant. Orchards. May 3 and September.

Cape May Warbler. Dendroica tigrina. Rare transient visitant, May is to September 20.

Yellow Varbler. Dendroica aestiva. Common summer resident, May I to October. Orchards and willows.

Black-Throated Blue Warbler. Dendroica coerulescens. Rather common transient visitant, May I 2 to September. Orchards.

Myrtle Warbler. Yellow-Rumped Warbler. Dendroica coronata. Common transient visitant, April 20 to September. Roadsides.

Magnolia Warbler. Black and Yellow Warbler. Dendroica maculosa. Common transient visitant, May 12 and September. Roadsides.

Chestnut-Sided Warbler. Dendroica pensylvanica. Common summer resident, May 6 to September. Thickets by roadsides.

Bay-Breasted Warbler. Dendroica castanea. Common transient visitant, May 10 and September 24. Roadsides.

Black-Poll Warbler. Dendroica striata. Common transient visitant, May 17 and September i 4 . Trees and shrubs.

Blackburnian Warbler. Dendroica blackburniae. Common transient visitant and rather rare summer resident, Nay 9 to September I 4 . Our woods. 
Black-Throated Green Warbler. Dendroica virens. Common summer resident, May I to October. Our woods.

Pine Warbler. Dendroica vigorsii. Common summer resident, April 12 to October. Pine woods.

Palm Varbler. Dendroica palmarum. Uncommon transient visitant, September I 4, 1904. Roadsides.

Yellow-Palm Warbler. Yellow Redpoll. Dendroica palmarum hypochrysea. Common transient visitant, April 12 to October. Roadsides.

Prairie Warbler. Dendroica discolor. Rare summer resident. One record, May 44 to October 26, I 90 I. Pastures.

Oven-Bird. Golden-Crowned Thrush. Seiurus aurocapillus. Common summer resident, May 3 to September. Woods.

Northern Water-Thrush. Seiurus noveboracensis. Common transient visitant, May 9 and September 20. By Wrangling Brook.

Louisiana Water-Thrush. Seiurus motacilla. Very rare summer resident or accidental visitant. Two records, 1905 and 1906. Nashua River bank.

Kentucky Warbler. Geothlypis formosa. Rare accidental visitant. One record. Our lawn, May 9, r $90 \mathbf{r}$.

Connecticut Warbler. Geothlypis agilis. Transient visitant, September 20. Rare. Roadsides.

Maryland Yellow-Throat. Geothlypis trichas. Common summer resident, May 3 to October. Thickets.

Yellow-Breasted Chat. Icteria virens. Very rare accidental visitant. One record, April 30, I900. Thicket.

Wilson's Warbler. Sylvania pusilla. Common transient visitant, May 15 to September. Roadsides.

Canadian Warbler. Sylvania canadensis. Common transient visitant. Orchards. May I 5 and September.

American Redstart. Setophaga ruticilla. Common summer resident. Main Street. May 4 to September.

American Pipit. Titlark. Anthus pensilvanicus. Rare accidental visitant, November I 4, 1902. Gibbet Hill and other high open fields.

Mockingbird. Mimus polyglottus. Rare permanent resident. Lowthorpe, I 908. Stone Quarry road.

Catbird. Galeoscoptes carolinensis. Common summer resident, May 5 to October. Thickets.

Brown Thrasher. Harporhynchus rufus. Common summer resident, May I to October. Thickets. 
House Wren. Troglodytes aedon. Once common summer resident. Rare now. May to September. Bird houses, fence posts, etc.

Winter Wren. Troglodytes hiemalis. Transient visitant, April and September. Brush.

Short-Billed Marsh Wren. Cistothorus stellaris. Rare summer resident, May 20 to September. Quasoponagon meadows.

Long-Billed Marsh Wren. Cistothorus palustris. Not very common resident, May ig to September. Quasaponagon meadows.

Brown Creeper. Certhia familiaris americana. Common winter visitant, October 27 to March. Tree trunks.

White-Breasted Nuthatch. Sitta carolinensis. Permanent resident, common. Tree trunks.

Red-Breasted Nuthatch. Sitta canadensis. Rather rare winter visitant, October to April. Tree trunks.

Chickadee. Parus atricapillus. Common permanent resident. Birches and alders.

Golden-Crowned Kinglet. Regulus satrapa. Winter visitant, common, September to April. Buslies.

Ruby-Crowned Kinglet. Regulus calendula. Common transient visitant, April i 8 to October. Woods and orchards.

Wood Thrush. Turdus mustelinus. Rather common summer resident. May I o to September. Reedy meadow. Black Pond.

Wilson's Thrush. Veery. Turdus fuscescens. Common summer resident, May 6 to September. Quasoponagon meadows.

Bicknell's Thrush. Turdus aliciae bicknelli. Rare transient visitant, September 9 and May I4. Long Hill.

Olive-Backed Thrush. Turdus ustulatus swainsonii. Transient visitant, May I to October. Roadsides.

Hermit Thrush. Turdus aonalaschkae pallasii. Common transient visitant and, since I904, quite common summer resident, April 17 to September 30. Rockwood's pasture. Black Pond.

American Robin. Robin Redbreast. Merula migratoria. Common summer resident, sometimes winter visitant. Everywhere. March 5 to November. A Robin roost is in Rockwood's pasture.

Bluebird. Sialia sialis. Common summer resident, Narch I to November. Orchards, roadsides.

Man-Bird. Aviator biplane. Variety Milling. Very rare transient Misitant. Sept. 3, I9 I I.

Bilviator monoplane. Variety Ovington. Very rare transient vissient vı. Sept. 3, I9 I1.

Our woo 


\section{MAMMALS - MAMMALIA. \\ Insectivora Order - Insect-Eating Mammals.}

Short-Tailed Shrew. Blarina brevicauda. Quasoponagon meadows. Common Mole. Scalops aquaticus. Quasoponagon meadows. Star-Nosed Mole. Condylura cristata. Quasoponagon meadows.

Chiroptera Order or Wing-Handed Mammals.

Hoary Bat. Lasiurus cinereus. Quite rare.

Red Bat. Lasiurus borealis. The most common Bat.

Little Brown Bat. Myiotis subulatus. Common.

\section{Rodentia Order-Gnazvers.}

Flying Squirrels. Sciuropterus volans. The animals are not so rare as it might seem, as they are nocturnal. Woods by Nashua River.

Red Squirrel. Sciurus hudsonicus. Eats young birds and eggs. Very common.

Gray Squirrel. Sciurus carolinensis leucotis. Next to the largest and tamest of our Squirrels. Growing more common every year.

Fox Squirrel. Sciurus niger cinereus. Rare. What is thought to be an unusually large Red or Gray is often the Fox Squirrel. I have never seen one in Groton, but they have undoubtedly lived here at some time.

Chipmunk. Ground Squirrel. Tamias striatus. Common everywhere, especially in old stone-walls.

Woodchuck. Arctomys monax. Common in fields.

Beaver. Castor canadensis. Very likely more than a hundred years ago the beavers built their dams in Groton. The remains of one may be seen in the Unquetenassett Brook on Mr. Frank D. Lewis's farm. Chicopee Row.

Muskrat. Fiber zibethicus. Common. Quasoponagon meadows.

Field Mouse. Microtus pennsylvanicus. Common in fields.

Deer or White-Footed Mouse. Hesperomys leucopus. More common than one might think, as it feeds at night.

Marsh Rat. Oryzomys palustris. Small. Seen swimming in the water. Wrangling Brook. 
The Jumping Mouse. Zapus hudsonius. Not very common. Prettiest and most graceful of any of the animals of this family. It hibernates, rolling itself up in a ball with its long tail wound around it.

Canada Porcupine. Erethizon dorsatus. Rare. My brother shot one about twenty-five years ago. A few days ago our dog came in with six porcupine quills in his nose, so there must have been or is one in this vicinity now.

Wood Hare. Gray Rabbit. Cotton Tail. Coney. Lepus sylvaticus. The common little brown hare. In woods.

Varying Hare. Lepus americanus. Rare.

\section{Hoofed Animals - Ungulata Order.}

American Deer. Dorcelaphus americanus. Largest native animal. Quite common. As many as tiventy-four have been seen at one time together.

\section{Carnivora Order - Flesh-Eating Mammals.}

Wildcat or Lynx. Lynx rufus. Reported at various times from the Throne.

Red, Black, or Silver Fox. Vulpes pennsylvanica. In rocky woods.

Raccoon. Procyon lotor. Quite common. Woods.

American Otter. Lutra canadensis. Rare. Wrangling Brook, also rivers.

Common Skunk. Mephitis mephitica. Common.

Weasel or Ermine. Putorius noveboracensis. Rare.

Mink. Putorius vison. Rare.

\section{Primates Order - Man Family.}

The North American Indian. Homo sapiens americanus. Once common, no longer indigenous. We have the Indian names left us. Indian arrow heads, etc., are often found in the fields on the Nashua River banks. The Indian Pump on Mr. Edmund Blood's farm is a curious-shaped ledge, with a spring spurting out of it. 'This location seems to be an ancient river bed.

European Race. There are twenty-two hundred and fifty-three specimens of this genus. Imported at various times. Some rare and odd species, but more of the common variety. These have driven 
the native Indian from their homes until they have become extinct for many years in these parts.

Thus endeth the reading of "the Story Book," Written for us in Groton,

Written for us in hedge and brook,

Stories never to be forgotten.

Elizabeth Sewall Hill. 


\section{THE GEOGRAPHY OF GROTON}

[The following paper was prepared originally for the use of the members of the Appalachian Mountain Club, on their visit to Groton, Saturday, September 18 , ISS6.]

\section{RIVERS.}

IN early times, before the original Plantation had been cut up in order to form other towns, the Nashua River flowed through the township of Groton for a distance of ten miles or more, and nearly bisected its territory; while to-day its course within the town's limits is hardly more than three miles. This river is formed by the union of two branches, known respectively as the North Branch and the South Branch, which come together at Lancaster. The former has its source in Ashburnham, near the foot of the Watatuck Mountain, and in Westminster, and passes through Fitchburg and Leominster; while the latter rises, in the neighborhood of the Wachusett Mountain, at Princeton, and among the hills of Rutland and Holden, and passes through West Boylston and Clinton. Both these branches for a considerable distance above their confluence are known also as the Nashua. The stream at Groton is about one hundred feet above tide-ivater.

At a very early period the Nashua River was sometimes called the Penacook, and at other times the Groton River. In Thomas Noyes's survey of the grant of Major Simon Willard's farm in the autumn of 1659 , the land is described as "lying and being for the most part on the east side of Groaten Riuer." And, again, at the session beginning on September 6, 1676, the approval of the General Court was given to Jonathan Danforth's survey of lands laid out to William Hauthorne, "lying in the wilderness; on the North of Groaten Riner at a place called by the Indians Wistequassuck," now within the limits of Townsend. At a later period it was more frequently referred to as the Lancaster River; and it is likely that the stream bore different names at different places along its course even at the same time. In the 
record of "The lands of Mr. Samuell Willard, which is layd out to him in the towne of Grotten," on September 29, I680, reference is made to the Nashawag River, - another form of spelling.

The Squannacook River forms the divisional line with Shirley for perhaps four miles, which is the whole distance of contact with that town. This stream rises in Ashby and flows through Townsend and by West Groton, emptying into the Nashua. The name is found in the Proprietors' records as early as the spring of 1684 .

\section{PONDS.}

BADDACOOK POND - lies about two miles east of the village near the Lowell road. It covers an area of $\mathrm{IO}_{3}$ acres, and is the largest pond in the town. It is mentioned in the record of James Parker's land under the date of July 6, I666.

The water furnished to the town by the Groton Water Company comes from the well dug in the immediate neighborhood of this pond.

Outlet: Baddacook Brook, which flows into Cow Pond.

BRown POND - a small pond on the road from Fitch's Bridge to West Groton, near Wrangling Brook.

Burnt Meadow POND - a small pond within the limits of Burnt Meadow.

CADY POND - a small and deep pond, covering perhaps two acres, lying less than a mile from the village in a southeasterly direction, near the Boston road. It was named after Nicolas Cady, one of the early settlers, who owned land in the neighborhood. This pond and Flat Pond, both very small, are the only ones in the town whose waters ultimately reach the Nashua River, the others flow into the Merrimack.

Outlet: a small unnamed brook running southwesterly into James's Brook. 
Cow Pond - sometimes called Whitney's Pond, in the easterly part of the town, covering an area of $7 \mathrm{I}$ acres. Cow Pond Meadow is mentioned in the record of Ralph Reed's land before the year I664.

Outlet: Cow Pond Brook, which flows into Massapoag Pond.

DUCK POND - near the Ridges, east of Knop's Pond, and separated from it by a ridge only - lies perhaps half a mile south of Cow Pond. It covers 55 acres, and has no outlet.

FLAT POND - a small sheet of water near the Throne, in the west part of the town.

Outlet: a small unnamed brook into the Squannacook River.

FORGE POND - in Westford, covering an area of 143 acres. In very early times it was called Stony Brook Pond.

Outlet: Stony Brook, which empties into the Merrimack River at North Chelmsford.

HALF-MOON POND - a small pond in the upper part of the meadow, which lies south of the Hillside Road.

Knop's Pond - near the Ridges, west of Duck Pond, and is of the same size as that pond, covering 55 acres. So called from James Knapp, or Knop, an early settler who owned land in the neighborhood.

Outlet: a brook into Cow Pond.

LONG POND - lies on the southern border of the town, partly in Groton, but mostly in Ayer, covering 45 acres.

Outlet: a brook into Sandy Pond.

MarTin's POND - near the foot of Gibbet Hill, on its northerly side-covers $162 / 3$ acres; it was named after William Martin, an early settler. Before coming to Groton, Martin had lived in what is now North Reading, where another pond was named for him. 
In the record of James Parker's land, on July 6, I666, "the pond called Goodman Martin's Pond" is mentioned. The following Article, found in the warrant for the town-meeting held on September I7, I792, seems to show that the outlet of the pond was formerly through Hog Swamp and HalfMoon Meadow into James's Brook, though there is now no other evidence to confirm this view.

Art. 8. To see if the Town will order the water running from Martin's Pond to be turned into the old Channel as it formerly used to run, through the Town, and appoint some proper person or persons to remove the obstructions and Effect the Business.

In the proceedings of the meeting, it is recorded that this Article was "Past in the Negative." A measurement of the pond was lately made, when frozen over, which proves it to be much smaller than it was a half century ago.

Outlet: Martin's Pond Brook into the outlet of Knop's Pond, half-way between that pond and Cow Pond.

MASSAPOAG POND - on the eastern border of the town, but lies mostly in Dunstable and Tyngsborough, covering an area of 56 acres. It is now used as a storage basin of water by the Vale Mills Manufacturing Company of Nashua, New Hampshire, and in dry seasons it is drawn upon for a supply.

Outlet: Salmon Brook, which empties into the Merrimack River at Nashua.

SANDY POND - lying wholly in Ayer, and covering So acres. A large quantity of ice is taken from its surface in the winter, the ice-houses on its borders being connected with the Fitchburg Railroad by a branch road.

Outlet: Sandy Pond Brook, which flows into Nonacoicus Brook.

SPRINGy POND - a small sheet of water connected with Knop's Pond by a brook.

Swax POND - was formerly a small sheet of water, which has now entirely disappeared, and is forgotten by the present 
inhabitants of the town. It lay north of the road from Groton to Forge Village, very near the Westford line, and is represented by a piece of low land, out of which a brook runs into Forge Pond, which in early times was called Stony Brook Pond. This little stream was formerly known as Swan Brook, and is referred to in the record of James Knop's land-grant, made by John Morse, town-clerk, on January 3, 1669. See "The Early Records of Groton" (p. 165). It is also mentioned by Captain James Parker, William Lakin and James Knop, in a report made by them April 25, 1682, on Jonas Prescott's land lying near his mill (ibid. pp. 73,74). Swan Pond is laid down on a manuscript plan of Sergeant John Parker's farm "on the South of Groaten Towne," which was made by Joseph Danforth, surveyor, in the year I664. The writing is to be found among the Massachusetts Archives, in the first volume (p. 3I) of "Ancient Plans Grants \&c."

The pond undoubtedly took its name from the swan $(C y g$ mus ferus), which formerly, at particular seasons, frequented this neighborhood. Thomas Morton, in his "New English Canaan " (Amsterdam, I637), writes:--

And first of the Swanne, because shee is the biggest of all the fowles of that Country. There are of them in Merrimack River, and in other parts of the country, greate store at the seasons of the yeare (p. 67).

WATTLE'S POND - three miles north of the village, on the road to East Pepperell, with no outlet. The origin of the name is unknown, but probably it goes back to the time of the early settlers.

IVAY POND - In the town-records, as early as the year 1670 , and in the Proprietors records, occasional reference is made to Way Pond, a name which has now passed entircly out of the public memory. It lay thirty or forty rods south of the road to the Ridges, a little less than two and a half miles from the First Parish Meeting-house. All that now remains of the pond is a mud hole, covering half an acre, more or less, through which a brook runs, crossing the 
Boston road near the house of Luther Gilson, - as given on Mr. Butler's Map of Groton, from a survey made in the years I \$2 8 and I 829 , - and emptying into Cow Pond. This little stream might well be called Way Pond Brook.

In this list of ponds I have included two or three which now lie wholly in other towns, inasmuch as they are frequently mentioned in the Groton records. The area of the ponds, with the exception of Martin's Pond, is taken from the Fourth Annual Report of the State Board of Health of Massachusetts (January, I873), as given on pages I24 and I 25 .

An absurd story is told relative to Massapoag Pond, based on tradition, which has no real foundation. It is said that -

Its outlet was on the easterly side, and as it was the reservoir into which Cowpond brook poured its waters, a considerable mill-stream issued from it. The waters passed without any rapids for a considerable distance, affording no favorable site for a mill. The north end of the pond was bounded by a ridge of loose sand, rising but little above the surface of the water, and being about six rods only in width ; on the opposite side of which was a descent of about forty feet. Here, then, was an eligible spot for an overshot mill. At a town meeting held May 2I, 1688, a grant was made to Samuel Adams of a small pond near Buck meadow, and leave given to drain it by a brook running into "Tyng's cove." At the same meeting, for the encouragement of any who would set up iron-works at Massapoag, a grant was offered of the wood on the easterly side of Unquetenassett brook. It is said that Adams, who is supposed to have accepted the grant, erected a grist-mill at the site above-mentioned, conducting the water across the sand-bank to the flume of his mill. At the time of a flood about the year 1700 , (the precise time is not known,) a breach was made across the sand-bank, and it being very loose and moveable, the whole bank was soon torn down by the water to the depth of more than thirty feet : and consequently a sheet of water of that depth, where the pond was so deep, and where of less depth the whole water upon the surface, flowed suddenly off (all in one night,) with irresistible violence. The mill of course was demolished, and the stones, though diligently sought for, and even the skill of the famous Moll Pitcher, of Lynn, employed in the search, have never yet been found. The bottom of the pond being uneven, fish in abundance were left in the 
cavities, which were easily taken, and the inhabitants of the neighboring towns, as well as of Groton, came and carried off loads of them. Where the water formerly issued from the pond, a small brook now runs in, and the outlet is, at the place of disruption, called the "gulf." The water finds its way into the old channel, two or three miles from the pond, in a north-westerly direction from Dunstable meeting-house.

(Butler's History of Groton, pp. 246, 247.)

The name of Buck Meadow, which has been in use for more than two centuries, is firmly established, and the site well known. The meadow lies near Lovewell's Pond, formerly within the limits of Groton, but now in Nashua; and Adams's mill stood undoubtedly at the outlet of this pond, where there is a small water-power. This theory would tally with the town-records; and furthermore a tradition is still extant that there was once a mill in the neighborhood. Lovewell's Pond is much smaller than Massapoag, and at that time probably had no designation. It was named after Captain John Lovewell, who was killed by the Indians on May 8, 1725. The following is the entry in the records:-

May: 2r. I688 The inhabitants of Groton Granted to Samull Adams $y^{e}$ pond that lyes neare buck medow which hath its outlet into the medow known by $\mathrm{y}^{\mathrm{e}}$ name of Tyngs Couee and the swampy land adioyeng ther to prouided $y^{\mathrm{e}}$ sd land do not exceed fifteen accers ;

atest; Josiah PARKer Clarke

and sd adams hath liberty to drean the $\mathrm{s}^{\mathrm{i}}$ pond at $\mathrm{y}^{\mathrm{e}}$ small brook that unes in to Tyng's Coue prouided sd Adames macks good all dameges that shall be don ther by

There are now three small brooks running into Massapoag Pond on the easterly side, and their fall is too great for any one of them ever to have been the old outlet of the pond. Furthermore, it would have been impossible by any of these brooks to drain the pond (which even at the present time covers 56 acres) without causing too great damage for Adams to make good. There is no indication along their banks that they have been much larger streams than they are to-day. While the formation of the banks at the mouth of the pond, 
or the "gulf," so called, is peculiar, there are no signs that the water-line was ever any higher than it is at the present time. None of the local antiquaries is able to identify Tyng's Cove, which is a name undoubtedly derived from Jonathan Tyng, one of the earliest settlers of Dunstable.

At the same town-meeting, held on May 2I, I688, the inhabitants of Groton -

deed then by the maior uoat grant for the incoregment of such men as will set up Ioran works at masabog pond; that thay shall have $y^{e}$ ues \& improument of the woods and timbr $y^{t}$ is now common one the est sid of uncuttanaset brook and so to nashua riuer and groton line est ward $\&$ south ward to good man greens masabog medow. ...

I give this extract from the town-records in order to show that the inhabitants at that period knew the pond by its present name; and if they had seen fit then to grant Adams any special privilege connected with it, they would have called it "Massapoag," and would not have said " $y^{\mathrm{e}}$ pond that lyes neare buck medow."

\section{HILLS.}

BARRALOCK HILL - is mentioned in the record of Samuel IVoods's lands. It is the hill due north of Baddacook Pond.

BROWN LOAF HILL - commonly called Brown Loaf - is a handsome, symmetrical hill standing alone, more than a mile from the village, near the Lowell road. Brown Loaf Hill Meadow is mentioned in the description of Joseph Parker's lands, December 2, I664, which would imply that the hill was so named before that time. Brown Loaf Hill is also mentioned in the record of James Parker's lands made on July 6, I666; and Brownloafe Playne and Brownloaf Hill are given in the record of James Fisk's lands in John Morse's hand. writing, of which the date is absent, but which was certainly made at a very early period. 
Chestnut Hills - the range lying northerly of Martin's Pond; so called from the abundant growth of chestnut-trees on its sides, and now owned by Lawrence Brooks. The highest elevation in town.

ClAy-Pit HiLL - the small hill at the corner of the East Pepperell road and Break Neck.

GibBET HiLL - a noted landmark, overlooking the village on its easterly side. It is mentioned in the land-grant of Sergeant James Parker, which was entered in the townrecords by Richard Sawtell, the first town-clerk who filled the office, from June, I662, to January, I664-65. An unlikely tradition is that the hill was so called from the fact that once an Indian was gibbeted on its top. If this ever occurred, it must have happened before Sawtell's term of office. The town was incorporated by the General Court on May 25, I655, but 110 public records are known to have been kept before June 23 , I662.

HoRsE HiLL - in the eastern part of the town, near Massapoag Pond. It lies partly in Dunstable, and is covered with woods.

INDIAN HILL, or HILLS - the range beginning near James's Brook, a mile south of the village, and running in an easterly direction on the south side of the Great Road to Boston.

LONG HILL - leading westerly from Farmers' Row down toward the Red Bridge.

NAUMOX - a low hill or ridge a short distance west of the road to East Pepperell, near the Longley monument, and running parallel with the road. The name is said to be that of an Indian chief, and is also used in connection with the neighborhood.

Prospect Hill - very near Cady Pond, and east of it.

Ridge Hill, or The Ridges - the name of a peculiar ridge, three miles southeasterly from the village, along which 
the Great Road runs. It also gave the name to a tavern formerly kept in the immediate neighborhood.

ROCKY HILL - there are two hills of this name, one lying northeasterly of Baddacook Pond, near the old District Schoolhouse No. VIII. (now the Trowbridge School), which is also known as the Rocky Hill School; and the other situated in the southeast part of the town, between Long Pond and the Ridges. A visit to either of these hills will show why it was so called.

SAND HILL - a small elevation on the road to East Pepperell, below the Longley monument, near the place where the Nashua road branches off.

Shepley Hit.L - lies west of the East Pepperell road, near Naumox. The name is rarely heard now, though it was in use as far back as February 28, I670, - evidently so called from the Shepley family.

SNAKE HILL - in the south part of the town, but lies mostly in Ayer. Rattlesnakes have been killed on it within the memory of the present generation.

THE THRONE - a high hill in the western part of the town, - on the summit of which is a level field of perhaps sixty acres, containing a small pond, - near the Townsend line. A map of Groton resembles a tea-kettle, the portion west of the Nashua River forming the spout; and the Throne comes in the spout.

\section{MEADOWS.}

The early settlers of Groton, according to the town-records, had many parcels of meadow allotted to them in the assignment of land. Sergeant James Parker owned in twenty different meadows, and the other settlers also were large owners. It is probable that they did not attach the same signification to the word "meadow" which now belongs to it in New England, where it means low, swampy land, without regard to the 
mowing. They called by this name all grass-land that was annually mown for hay, and especially that by the side of a river or brook; and this meaning of the word was and still is the common one in England, whence they brought their language. They sometimes spoke of a "swamp," meaning by it what we call a "bog; " but much of this kind of land has since been reclaimed, and is known with us as "meadow." As a matter of fact it happened that the lands which could be mown for the fodder were low lands, and it would require perhaps less than a generation to transfer the meaning of mowing lands to the low lands, which were nearly the only ones that could be mown in the early days of the Colony. This explanation will make clear the following vote of the town, passed on February is, i680-8 I :-

At the same meeting it was agreed vpon and voted that $\mathrm{M}^{\mathrm{r}} \mathrm{Hub}-$ berd [Hobart the minister] should haue all the comon which was capable to mak medow in swan pond medow vp to the vpland for seauen acre and a halfe for to mak vp his fifteen acres of medow

The following names of meadows are found in the townrecords, and in a few instances I have indicated their locality:

Accident; Angle, in the northerly part of the town; Big Spring, in the neighborhood of Hawtree Brook; Broad, immediately west of the village; Brook; Brown Loaf, east of the hill; Buck, now lying within the limits of Nashua, New Hampshire; Burnt, east of the highway running from the Lowell road to the Rocky Hill school; Cow Pond, near the pond of that name; East ; Ferney, near Brown Loaf; Flaggy, to the southward of the Baddacook road, near the pond; Flax; Great Flaggy, presumably near Flaggy, and perhaps the same; Great Half-Moon, the same as Half-Moon, which lies east of the village; Little Buck, probably a part of Buck Meadow; Little Half-Moon, a part of Half-Moon, being an offshoot from it; Lodge; Long; Maple; Massapoag, evidently near Massapoag Pond; New Angle; Pine; Plain; Pretty; Providence; Quasoponagon, "on the other sid of the river," near the Red Bridge, through which Wrangling Brook runs; Reedy, known by this name to-day, lying north of the 
Reedy Meadow Road; Rack, south of Snake Hill; Sallo, perhaps Sallow, a kind of willow; Sedge; Skull, through which Unquetenassett Brook runs, near the Dunstable line; Sledge, north of Reedy Meadow, near the Sledges; South; South Brook; Spang; Spot; Spring; Spruce ; Swamp ; Swan Pond ; and Veavers.

In the record of Daniel Pearse's land, by William Longley, town-clerk, on July 6,1666 , reference is made to "the iland lying within the meadow called Litle Halfe Moone Meadow." This land formerly belonged to Governor Boutwell; and I was told by his son, the late Francis M. Boutwell, Esq., that there is upon it a small elevation, which is always spoken of as the island, - undoubtedly a survival of the expression applied to it when more or less surrounded by water.

\section{BROOKS.}

COLD SPRING BROOK - a small brook, rising in Cold Spring " on $y^{\mathrm{e}}$ Left hand of the high way that goe to Reedy meadow." It runs across the Nashua road, the East Pepperell road, through Hazen Swamp and Libby Lobby Moat, into the Nashua River.

Cow POND BROOK - has its source in Cow Pond Meadows and Cow Pond, and empties into Massapoag Pond. Formerly there was a dam between the meadows and the pond, where there was a saw-mill; and, later, on the same site a paper-mill, which was taken down about fifty years ago.

GIFT Brook - in the north part of the town, rises in Gift Meadow, crosses Chicopee Row near James Bennett's house - as laid down on Mr. Butler's Map - and empties into Unquetenassett Brook.

JAMES'S BROOK - one of the longest brooks within the limits of the town. It takes its rise in Half-Moon Meadow, crosses Main Street in the village, and runs southerly and 
westerly for three or four miles into the Nashua River. At its mouth is the beginning of the line separating the town of Ayer from Groton. Formerly there was a tannery on the banks of the brook, near Indian Hill, known as Dix's tannery; and a mile below, on land of the late Benjamin Moors, east of the road, at one time there was a mill, - but now no traces of either are left, beyond signs of the mill-site. It empties into the Nashua River, nearly opposite to the mouth of the Squannacook.

HAWTREE BROOK - in the northerly part of the town, near Chicopee Row; after it unites with Walnut Run and two or three other small streams, it forms Unquetenassett Brook. In the early records of the town the Hawtrees are frequently spoken of, which refer to the neighborhood of this brook.

NOD BROOK - rises near the Soapstone Quarry, crosses the Nod road and runs into the Nashua River.

Nonacoicus Brook - frequently contracted into Coicus - was formerly a noted stream in Groton; but now no part of it comes within the limits of the town. It has its source in Harvard, and runs northerly and then westerly, passing through the village of Ayer, and emptying into the Nashua. It receives, as a tributary, Sandy Pond Brook. On this stream John Prescott, about the year I667, built his mill for grinding and sawing, of which the site was originally in Groton, but now is in Harvard. The neighborhood is still called the Old Mill.

ReEdy Meadow Brook - rises in Reedy Meadow and flows northerly, emptying into the Nashua River below East Pepperell. It is sometimes called Johnson's Brook.

SANDY POND BROOK - wholly in Ayer, the outlet of Sandy Pond, flowing into Nonacoicus Brook.

SEDGE BROOK - a small brook from Sedge Meadow, running into Reedy Meadow Brook. 
STONY Brook - in Westford, the outlet of Forge Pond. It was on this stream that John Prescott built a mill about the year 1683. See "The Early Records of Groton" under the dates of June I 5, I680, June I 3, I68 I, and April 25, I682, also the agreement following the record of the meeting held on June 25,1683 .

SWAN BROOK - was the brook near the divisional line between Groton and Westford, which flows into Forge Pond. See the entry of James Knop's lands, made on January 3, I669, in "The Early Records of Groton."

TUITY BROOK - contracted from Gratuity - a very small stream which rises near the head of Farmers' Row and runs through Hazle Grove into the Nashua River below Fitch's Bridge.

UNQUETENASSETT BROOK - often called Unkety - a stream formed by the union of Walnut Run, Hawtree Brook, and one or two small tributaries, and running northerly through Skull Meadow and that part of Dunstable formerly Groton, into the Nashua.

WALNUT RUN - a brook issuing from the sides of the Chestnut Hills, and uniting with Hawtree Brook and one or two other streams, forms the Unquetenassett.

Also the name of a place - perhaps it was the mouth of a stream - on the Nashua River where in olden times there was a bridge. It stood further up the river than Fitch's Bridge.

Wrangling Brook - in West Groton, a mile and a half in length - meanders through Quasoponagon Meadow, and then empties into the Nashua a short distance below the Red Bridge. Miss Hill lives near this brook, which accounts for the frequent mention of the Quasoponagon meadow. 
ROADS.

BADDACOOK POND ROAD - a continuation of the Martin's Pond Road to the neighborhood of the pond.

BREAK NECK - the short strip of road from the East Pepperell Road to Common Street, south of the soapstone quarry.

CHICOPEE Row, or ROAD - running north for three miles from the Cemetery. This district is known as Chicopee, a name given long ago.

FARMERS' ROW - applied to the road on the height of land west of the village. It begins at the west end of Pleasant Street and runs in a southerly direction for two miles, passing by the Groton School. It has been so called since the eightcenth century, according to the testimony of my own family who have lived there for many years.

GREAT ROAD - one of the principal thoroughfares between Boston and parts of New Hampshire and Vermont. The section of the road through the village is known as Main Street.

HILLSIDE ROAD - the highway along the southern slope of the Indian Hills.

Love LANE - the highway from the Lowell road, near the First Parish Meeting-house, to the Great Road near Cady Pond.

MARTIN'S POND ROAD - the highway from the site of the first meeting-house to the neighborhood of the pond, where it becomes the Baddacook Pond Road.

ReEdy Meanow RoAd - from the Nashua Road to Chicopee Row, immediately south of Reedy Meadow.

SquASH PATH - through the woods from the East Pepperell road to the Nashua road - a short distance beyond Cold Spring Brook. Perhaps the name is an abbreviation of musquash. 
TUiTy ROAD - a contraction of Gratuity Road - the road leading to Fitch's Bridge from the Great Road near the Railroad Bridge, half a mile north of the village. The name had its origin in the early history of the town, when grants of land were made to the inhabitants as gratuities. Tuity Brook, a very small stream, crosses this road and empties into the Nashua River, below Fitch's Bridge.

\section{MISCELLANEOUS.}

BLOOD'S FORDWAY - near the covered bridge in East Pepperell, which is often called Jewett's Bridge.

BRICKYARD - on the north side of the Great Road, about a mile from the First Parish Meeting-house. It was much used during the last century; and probably was the place where the bricks were made for the parsonage, as mentioned in the town-records, June 20, I 706. Only a few traces of it are now left, though a clump of elms by the roadside is a good guide to the site.

Brown LOAF PLAIN - to the west of Brown Loaf.

Community - the name of a district or neighborhood beyond the Groton School, where many of the residents formerly held sinilar religious views. It had its origin about sixty years ago, when the Second Adventists, or "Millerites," gave up their regular services in the village. See Edward A. Richardson's pamphlet on "The Community" (I9II).

DEAD RIVER - the old course of the Nashua River, around the island which was formed by the cutting through of the "neck." See page I08 of this book.

DeEP SOIL - in the neighborhood of the race-course, in Hazle Grove; so called on the lucus a non lucendo principle.

FITCH'S BRIDGE - over the Nashua River, a mile and a quarter below the Red Bridge. 
GENERAL FiELD - often mentioned in the early townrecords, refers to land owned in severalty by the proprietors of Groton, who kept it as one field, for reasons not now understood. It was upland, and lay in the southwest part of the town, near the river. It appears to have been allotted to the proprietors, according to the number of acre-rights which each one owned. Perhaps it was land already cleared when the first settlers came.

THE GIFT - a parcel of land near Reedy Meadow, not distinctly identified.

THE HAWTREes - mentioned several times in the early records, and referring, doubtless, to some native shrubs or trees; for instance, Zachery Sawtell had meadow-land "Neare the hawtrees" confirmed to him on November is, I670. It evidently became the name of a limited district or neighborhood in the north part of the town, and from it undoubtedly Hawtree Brook was named. Professor Asa Gray, the distinguished botanist, wrote me many years ago that there were three or four species of wild hawthorn in Massachusetts. He says: "One of the forms of the Black or Pear Thorn (Cratagus tomentosa) would be the likeliest for Groton, or perhaps the Cockspur Thorn. The former has the more edible fruit, and would be sure to attract attention."

HAZEN SWAMP - near the mouth of Cold Spring Brook.

HAZLE GROVE - the neighborhood of the east bank of the Nashua River above Fitch's Bridge. The Groton Farmers' and Mechanics' Club owns a tract of land in this Grove, where it holds annual exhibitions. Its display of fruit, flowers and vegetables, with that of its horses, cows and poultry, is somewhat famous in the towns around.

Hicks's Hole - a small piece of meadow, lying north of Reedy Meadow.

HigH PLAIN - on the north side of the Baddacook road, in the neighborhood of the pond. It lies in the angle of the roads, west of the house of John Johnson, Jr., as laid down on the map of Groton, made from a survey during the years I $82 \mathrm{~S}$ and 1829. 
Hog Swanp - lying between the westerly side of Martin's Pond and Martin's Pond Road. Mr. Lawrence Brooks's private way to his house and the Chestnut Hills passes through it.

HoYT'S WHARF - the name of a place on Cow Pond Brook where one Hoyt formerly kept his boat. It was near the house of Samuel Hazen, - as laid down on Mr. Butler's map of Groton, made from a survey during the years 1828 and I 829, - nearly a mile north of Cow Pond.

THE ISLAND - a small, though prominent, hill in the meadow south of Hillside Road; undoubtedly once surrounded by water.

JANAICA - the name of a small patch of meadow behind the hills on the west side of Chicopee Row.

Libby LobBy MoAT-below the Ox Bow, opening into the Nashua River. This word is probably another form of Loblolly, in use at the South, and denoting wet land.

LILY MOAT - on the east side of the Nashua and south of the road, near the Red Bridge.

MADAGASCAR - the name of the district where the papermill formerly stood on the brook, between Cow Pond and Knop's Pond.

$\mathrm{NOD}$ - the district lying in the neighborhood of the four corners, below the soapstone quarry. The road from the Hollingsworth Paper-mills to this place is called the Nod Road.

Ox Bow - the bend of the Nashua River, in the northerly part of the town, below the Lawrence pasture.

Palgus Hole - in Paugus Brook, on the west side of Brown Loaf, where, it is said, the body of Paugus's descendant, who came to kill Chamberlain, was sunk, after he himself was killed.

Pine Plati - probably near the Nashua River, and on the westerly side. In December, I673, Joseph Morse had meadow-lands on the Pine Plain, "neare the fordway." 
Punch Bow' - one of several natural depressions near the Lowell road, below Brown Loaf. The name is also applied to the district or neighborhood.

RED BRIDGE - over the Nashua River, on the road to West Groton.

SLEDGES - the name of a meadow northeast of Reedy Meadow, mentioned in the early records, where John Lakin owned land. Mr. Butler, in his History (p. 273), says that " this word seems to signify strips of meadow or parcels of low lands abounding in iron ore." Bog-iron is found in that quarter of the town, and in old times was worked by a company formed for that purpose.

SODOM - the district in the northeast part of the town, near the Townsend line. The name refers to the quality of the soil, and not to the character of the inhabitants.

SeUAnNACOOK - an Indian word, the old name of the village of West Groton.

Stony Fordinay, or Wading-Place - near the site of the Hollingsworth Paper-mills, on the Nashua River, a mile and a half northwesterly of the village.

SwILL BRIDGE - was between the homesteads of Eber Woods, Jr., and Joel Davis, - as given on Mr. Butler's map of Groton, from a survey made in the years 1828 and I829,a short distance west of the present railroad bridge. Originally it was a causeway, perhaps twenty rods in length, over the southerly end of Broad Meadow, though now it is a solid road.

Thomas TARBELl's Fordway - was between where the Red Bridge now stands, and Fitch's Bridge, which is a mile and a quarter below.

Tobacco Pipe Plain - on both sides of the road from the Ridges to Sandy Pond, near Rocky Hill. It is mentioned in the "Bye-Laws of Groton relative to Schools; and Instructions of the School Committee, ISO5," and in old deeds. 


\section{CULTIVATION OF HOPS.}

Dr. Samuel A. Greex, Boston:

Groto., July i 3, 1S97.

DEAR SiR, - My reply to your inquiry as to the culture of hops in the northwestern part of Middlesex County and the northeastern part of Worcester County during the first half of this century, must, in the nature of the case, be brief and imperfect. I can only conjecture the time when the cultivation of hops there began, but the probability is very strong that it was during the last decade of the last century. My grandfather, Jacob Marshall, who lived in Lunenburg, was a hop raiser, and his experience in that business must have been as early as the first part of the present century. He was the inventor of the press for pressing hops, which was afterward and almost immediately used for pressing cotton also.

The power for pressing hops, used by him and used in that district as long as hops were raised, was the screw as applied in a common cider mill. The hop vine was trained, or trained itself, perhaps, on poles, which in the culture were from two to four inches in diameter at the base and fourteen to fifteen feet in length. The hills in the field were set at a distance of perhaps five feet apart, and averaged about one thousand to an acre.

'The picking commenced usually in the last week of August, and continued often until far into the first half of September. The vines were cut and the poles taken out of the ground by men and laid upon long bins sufficient to receive the entire length of the vine, which was usually not less than twelve feet. The picking was done by young people, boys and girls, who stood on each side of the bin.

The product from one acre was about 1,000 pounds, or a pound to a hill, of clry hops. The drying was carried on in a building erected for the purpose, the hops being laid over lattice-work on the floor; and a fire of charcoal underneath furnished the heat for drying. This process was a delicate one, as it was necessary to extract all the moisture from the hops and to avoid scorching, as that injured the value in the market.

In the period of time when I had some knowledge of the trade in hops, say from 1836 to 1846 , the price varied from $\$ 10$ or $\$ 12$ to $\$ 50$ per bale, of about 200 pounds. The product of an acre in money, therefore, never exceeded about $\$ 250$, and more frequently 
the price was about 10 cents a pound or $\$ 20$ a bale, which gave to the grower ahout $\$$ roo as the gross return per acre. This extreme variation in prices led to speculation in hops both by the growers and the traders Sometimes a farmer would hold his crop, when it could have been sold at i 2 to 15 cents per pound, with the idea that some time in the future he might realize 25 cents, and not infrequently he was doomed to sell his crop for 8 to io cents per pound, or even, occasionally, as low as 6 cents. For the purpose of the trade in hops, Groton was the center for the product of the towns of Pepperell, Townsend, Ashby, Dunstable, Tyngsborough, Westford, Littleton. Boxboro, Harvard, Shirley, and Lunenburg.

The product of all these towns in the years when the culture was largest may have amounted to 500 bales, equal to about 50 tons. Mrr. Henry Woods at Groton, who was a dealer in hops, in one year bought and sold, either on his own account or on commission, about 350 bales, which may have been about seven-tenths of the entire product of the towns named.

Between the years 1840 and 1850 the growing of hops was transferred to the State of New York, where the crop could be produced at less cost; and more recently it has passed to the extreme northwest, largely to the State of Wisconsin. It is very doubtful whether a bale of hops has been raised in the towns named since the year I 855 .

Yours truly,

Geo. S. Boutwell.

\section{MOUNTAINS SEEN FROM GIBBET HILL.}

SEverAL years ago Mr. Edward G. Chamberlain, of Auburndale, in reply to a note, gave me some interesting facts in regard to certain hills and mountains, as seen from Gibbet Hill. Mr. Chamberlain is an enthusiastic member of the Appalachian Mountain Club, and very familiar with the heights and peaks of New England. By his courtesy in the matter, he has placed me under obligations to him for facts that could not be gathered from other sources. While Mr. Chamberlain has never been on Gibbet Hill, his opinions in regard to the distant range of mountains, as seen from that point, are entitled to great weight. The following letter will explain itself : - 
DR. SAMUel A. GREex:-

Auburidale, Mass., November 29, i\$93.

DEAR SiR, - I enclose the paper handed me on Monday at the Topographical Survey Office containing queries in regard to mountains seen from Gibbet Hill in Groton. I have laid out the bearings which you give, on a chart that I constructed some twenty years ago.

You make no question in regard to Joe English and the Uncanoonocks, and the bearings agree with the chart. Kearsarge you mark with a query, but it is undoubtedly correct. It is 2,948 feet above sea, distant from Gibbet 55 miles. Its profile from Gibbet wotild be probably something like this: _........, depending on how much of it you can see. This is compiled from sketches made from other points in Massachusetts. 'The mountain N. $8^{\circ} 40^{\prime} \mathrm{E}$. marked in pencil "Saddleback?" is probably Gunstock. 63 miles distant, 2,394 feet high, in the town of Guilford, N. H., just south of Lake Winnepesaukee. It is the middle and highest peak of the Suncook Mountains (or Belknap Mountains, modern name). I do not think I have ever seen it from any point in Massachusetts, unless from Wachusett. But from Groton you may look along the valleys of the Nashua, Merrimack, and Suncook Rivers, a direct line to the source of the latter in the Suncook Mountains. I wish the old name could be restored.

In regard to the two mountains seen from East Gibbet ( $\mathrm{N}$. I $8^{\circ}$ $50^{\prime}$ E. and N. $23^{\circ}$ E.), I am not so confident. The former may be Fort Mountain in Epsom, I,428 feet high, and $4 \mathrm{I}$ miles distant; and the latter, Blue Job Mountain in Farmington, about I 400 feet high, and 55 miles distant.

There is a range of hills sometimes called the Blue Hills (or Frost Mountains), extending N NE-S SW in the towns of Milton, Farmington, Strafford, Northwood, and Epsom, about I,000 to I,400 feet high. I have never explored them except from distant points with a glass. As near as I can make out, Saddleback is a comparatively low hill in the town of Northwood, which makes a fine show from the neighboring town of Deerfield, and used to attract some notice in stage-coach days; and so has become famous as Saddleback "in Deerfield." When any of its higher, but less known, neighbors are seen from a distance, they are at once identified as Saddleback. I do not think that I ever saw this mountain, but I have often tried to make it out. 
Fort Mountain in Epsom would probably appear like this from Groton. Blue Job I have never satisfactorily identified. The mountain seen in that direction you think is the most distant one visible. May it not thus appear so because of its low altitude, showing but little above the horizon, while Gunstock (if it be Gunstock) is not only better situated for exhibition, but (without computing) by its greater height may have greater apparent altitude, and so a clearer profile, even though further off?

Yours very truly,

E. G. Chamberlain.

Again, in continuation of the subject, Mr. Chamberlain writes, on December 20, 1893 , as follows:-

When studying the view from a hill I always used to compute the azimuth, or direction to all the points whose position had been determined; and if the Latitude and Longitude of the view-point had not been determined, I took measures to determine them myself, so as to compute the bearings. If you have the "Appalachia" magazine in your library, you may find my methods described in Volume III. (page 122), and Volume IV. (page $\times 32$ ). I have never visited Gibbet Hill, so I have made an approximate position by comparing several maps, and have plotted on my chart with the following results : -

\section{FROM GIBBET HILL.}

\section{Approximate Bearings and Distances.}

\begin{tabular}{|c|c|c|c|c|c|}
\hline & & $\begin{array}{l}\text { Approximate } \\
\text { Height. }\end{array}$ & Azimuth. & Bearing. & Distance. \\
\hline Wachusett Mt. & & $2018 \mathrm{ft}$. & $62 \frac{3}{4}^{\circ}$ & S. $62 \frac{3}{4}^{\circ} \mathrm{W}$. & I $8 \frac{1}{2}$ miles \\
\hline Watatick " . . & & I $847 " 6$ & $110^{\circ}$ & N. $70^{\circ}$ w. & I $7 \frac{3}{4}$ \\
\hline Mlonadnock" . & & $3170^{\prime \prime}$ & I $2 \mathbf{J}^{3^{\circ}}$ & N. $5^{8 \frac{1}{4}^{\circ}}$ iv. & $32 \frac{1}{2}$ \\
\hline Temple ". . & & $2050(?)$ " & I $32^{\circ}$ & N. $48^{\circ}$ w. & 22 \\
\hline S. Pack Monadnoch & & 2289 " & I $36 \frac{3}{4}^{\circ}$ & N. $43^{\frac{1}{1}}{ }^{\circ} \mathrm{W}$. & $23 \frac{1}{2}$ \\
\hline N. " " & & $2260^{\prime \prime}$ & $1403^{3}$ & N. $39_{4}^{10} \mathrm{w}$. & $24 \frac{1}{2}$ \\
\hline Crotchet Mt. . & & $2066 “$ & I $49 \frac{1}{4}^{\circ}$ & N. $30 \frac{3}{4}^{\circ} \mathrm{w}$ & $30 \frac{3}{4}$ \\
\hline Lyndeboro Pinnacle & & - & $152^{\circ}$ & N. $28^{\circ} \quad$ w. & $24 \frac{1}{2}$ \\
\hline Joe English . & & $12 \mathrm{So}(?)$ " & $167^{\circ}$ & N. $13^{\circ}$ w. & $23 \frac{3}{4}$ \\
\hline W. Uncanoonock. & & $1300(?)$ "6 & $174 \frac{3}{4}^{\circ}$ & N. $5_{4}^{10} \mathrm{~W}$. & 26 \\
\hline E. & & $1335^{66}$ & 177 & N. $3^{\circ}$ W. & $25^{\frac{1}{2}}$ \\
\hline
\end{tabular}


Joe English was a friendly Indian who in early times did many good turns for the white settlers; and he probably acquired his name from close association with them. While acting as a guard to Lieutenant Butterfield and wife, he was killed by hostile Indians between Dunstable and Chelmsford, in what is now Tyngsborough, on July 27, I 706. Joe English Hill in New Boston, N. H., the scene of some of his adventures, takes its name from him. 


\section{MOAT.}

TIIE two following letters are taken from "The Nation" (New York), under their respective dates, the first, December 5, I901, and the other, May 8, I902; and they explain themselves. "Moat" appears to be a folk-word brought over by the early comers, which took root in this neighborhood and has survived. Language is a growth, and not a creation; and it is always interesting to follow the many changes which come from natural evolution.

TO THE EDITOR OF THE NATION:

Sir, - In the town of Groton, Massachusetts, the word moat is given to a small body of water usually found at the mouth of various brooks which empty into the Nashua River. For ten, fifteen, or twenty rods above the outlet there is a considerable widening of the small stream; and the adjacent ground is wet and boggy. In the spring and summer this sheet of water is generally covered with lilypads, and is much frequented by pickerel. These pond-holes are commonly known among the farmers as moats - a term not in use with the same meaning in the neighboring towns, even though lying on the same river. It hardly seems probable that this use of the word is connected in any way with the ditch around a house or castle, filled with water. Groton is a town very nearly two hundred and fifty years old; and I am inclined to think that it is a folk-word, brought over from England by the early settlers.

Governor Boutwell writes me, under date of July io, 1901, that "the word moat has been in use in Groton during my residence in the town, now more than sixty-six years. At several points on the Nashua River there are shallow channels that are nearly parallel with the river, and that connect with the river at the lower end. These are filled with water from the river. There are two such moats on my premises."

I should like it if anybody can throw light on the derivation of the word.

Boston, November 21, 190I.

Saiuel A. Green.

To thie Editor of The Nation:

SiR, - Dr. S. A. Green last December called attention in the Nation to the local use in Groton, Mass., of the word "moat" as 
applied to certain brooks at their junction with the Nashua River. As Dr. Green's query concerning the origin and currency of moat appears to have elicited no response, I submit what follows:

Manifestly "moat" meaning hill or embankment is inapplicable to the thing called moat in the folk-speech of Groton. The thing described is a confluence, what the men of old time termed "a waters' meet." Moat signifying a trench filled with water is a technical term used in connection with works of fortification, and does not fit the facts given so well as " mote," a meeting or meet.

Stormonth's English Dictionary has: "Mote n. mot; also gemote, in Anglo-Saxon times, a meeting, as in the Witenagemot, the assembly of wisemen." Ward-mote and folk-mote are instanced. It may be added that, in the City of London, the meeting of the freemer at which Councilmen are elected is called "ward-mote" to this day. The Century Dictionary and Skeat (Etymological Dictionary) both treat mote as an obsolete form of moot, meaning meeting or assembly.

Numerous archaic compound words in which mote or mot signifying "meeting" occurs might be given; a few must suffice. Gomme, in "Primitive Folk-Moots," speaks of a Motestowhill near Stoneleigh, where the socmen held meetings. Worsaae, in his "Danes and Norwegians in England, Scotland, and Wales," says: "A document of the year $125^{8}$ conveys a gift of some ground in the suburbs of Dublin in Thingmotha (from mote, a meeting). The Thing place was near the present site of I)ublin Castle, the name of the surrounding parish was 'St. Andrew de Thengmote." Stubbs, in his "Constitutional History of England," vol. I., p. 43 I, notes the existence of tunscipesmot, township-meeting, shire-moot, hundred moot, and portmanmot, court of portreeve in boroughs. Vinogradoff, in "Villainage in England," cites sockemanemot and frankhalimote. Although Stormonth, Skeat, and the Century Dictionary all cite various kindred forms of mote in Anglo-Saxon or the Scandinavian tongues, none of them notices the use of mote or its Norse equivalents in the sense of junction or confluence. But Cleasby's "Icelandic-English Dictionary " has the following:

Mot (Anglo-Saxon gemot: Old English mote or moot in ward-mote; Danish möde, Swedish mot and möte) a meeting.

2. As a Norse law term; in Norway a mot was a town meeting and is opposed to thing, a county meeting.

3. A joint, juncture; ar-mot a meeting of waters, also a local name. [Compare Latin Confluentia, Coblentz.] 
According to Björkman's "Svensk-Englesk Ordbok," möte means confluence as well as meeting or assembly. $A a$ in Norwegian and Danish and $\mathrm{A}$ in Swedish signify a small river or streamlet, and we have in Swedish: $\AA$ mmun, rivermouth, $\stackrel{\circ}{b r y n}$, river brink, Astrand, riverbank, as well as Aafiord and Aamot in Norwegian. Aamot means " a meeting of waters" and "confluence." (See Geelmuyden's "Engelsk-Norsk Ordbok.") According to the "Dictionnaire des Bureaux de Poste" (Berne. 1895), Aamot, near Drammen, and Aamotsdal, near Skien, are post-offices in Norway. Map 95, g. 6, in the "Century Atlas" shows Aanot, in the province of Hedermarke, Norway, on the Glommen River.

Watersmeet, where the Combe Park Water joins the East Lyn River, a few miles above Lynmouth in Devonshire, England, is well known to tourists in the Doone country. Bagworthy Water is a stream in the same region. Watersmeet is found in Johnston's Atlas, I $S S_{9}$ (see Devonshire), and on the North Devon sheet, i. e., No. 27, of the maps of the Ordnance Survey. Again, Watersmeet appears as the name of a town in Michigan (see Map 22, C. 5, Century Atlas). Is water used as a synonym of brook or river anywhere in this country? Moore, in his Irish Melodies, sings of the "Sweet vale of Avoca," where "the bright waters meet." The waters whose meeting (mote) forms the Avoca (which is Celtic for "meeting of the waters," according to Chambers's Encyclopæedia), are the Avonbeg, or little river, and the Avonmore, big river.

The Celtic Avoca and the Norwegian Aamot appear to be closely synonymous with the Ievonshire watersmeet. One is inclined to ask whether $a a$ or mote occurs in the folk-speech of Devonshire, or of any other English county in which Norse influence is traceable. Maps of the Lake country present so many "waters" and "becks" that one is led to think that $a a$ or mote may still survive in the folk-speech of Cumberland or Westmorland.

It is likely that "mote," and not "moat" is the correct form of the word cited by I)r. Green, and that it was brought over sea from an early home of the Angles. Possibly there are other motes or meets in New England, but I have searched many maps for them in vain; nor have I found a mote on any map of East Anglia, or Friesland, or Denmark.

EDWard M. HaRTwell.

Boston, April 23, 1902. 
A third letter in "The Evening Post" (New York), May I2, I902, bears so closely on this subject that it is given here, as follows:

To the Editor of The Evenisg Post:

SIR, - In to-day's Evening Post Mr. Edward M. Hartwell of Boston gives the only correct explanation of the word "moat" as applied to certain brooks at their junction with the Nashua River in Massachusetts. In support of Mr. Hartwell's theory that the New England word is a misapplied technical term, and that "it does not fit the facts given so well as "mote,' a meeting or meet," I beg to quote the following Swedish words in addition to several English, Norwegian, and Swedish ones cited by Mr. Hartwell. In the county of Wermland, Sweden, there is a place called Amot, situated at the junction of two waters. In the county of Gefleborg, Sweden, there is a place called Amots Bruk, also situated at the junction of two streams.

There is also a Swedish word motvatten, but not a geographical name, signifying the water which in floodtine flows from a larger stream into a smaller estuary, backing up or meeting the water from the latter.

"Mote" is perhaps of Saxon derivation, from métan, to meet; mót, a meeting, etc. One finds the same word in the Icelandic: mata, to meet; and also in the Dutch: maten, to meet, and gemot, a meeting.

NEW York, May 8.

Axel C. Halleeck.

\section{SALMON IN THE NASHUA RIVER.}

A SALMON weighing $9 \frac{1}{2}$ pounds was caught recently in the Nashua River, near the Hollingsworth paper mills, at Groton. It is many years since this species of fish has been found in the neighborhood, but the provision now made for their passage over the dams, in going up stream in the spring of the year, renders it probable that others may be taken.

"Boston Journal," Sunday, May 12, I\$95.

From what I have since learned about this fish, I am inclined to think that it was a carp, and not a salmon. It was caught by a young man named Nutting. 


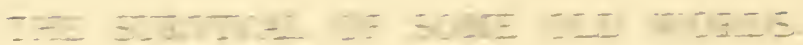

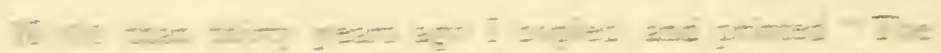

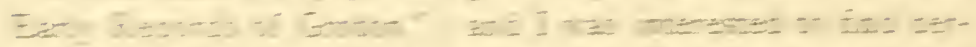

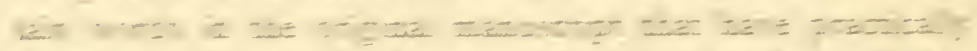
L

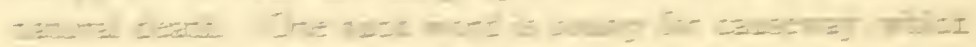

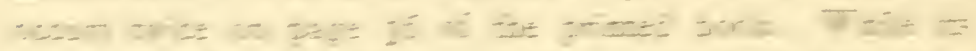

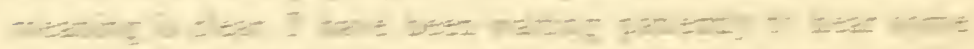

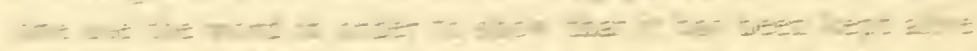

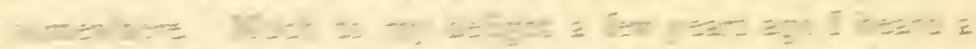

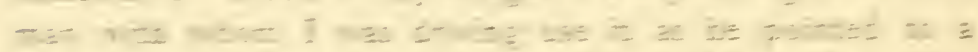

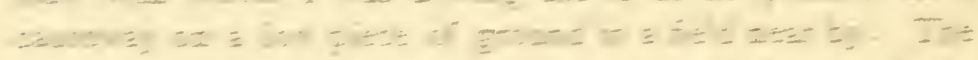

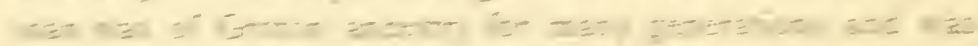

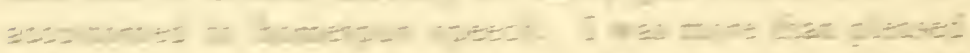

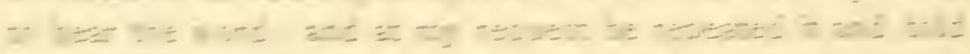

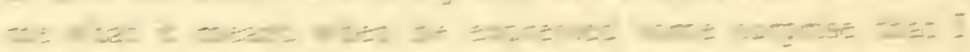

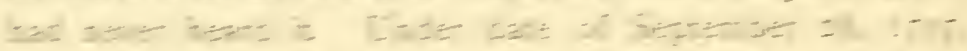

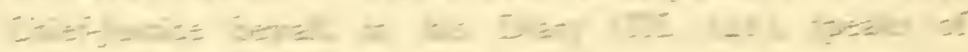

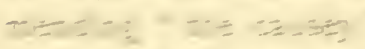

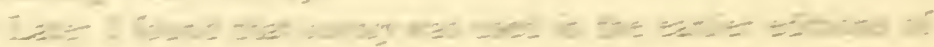

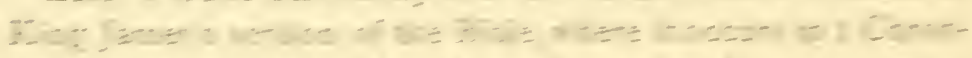

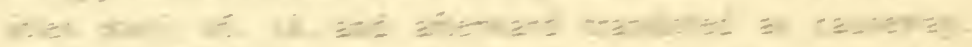

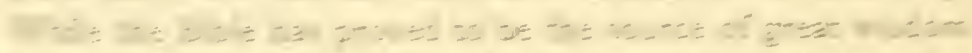

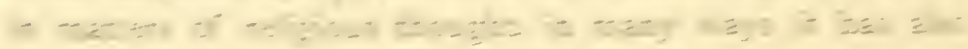

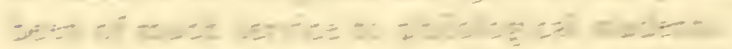

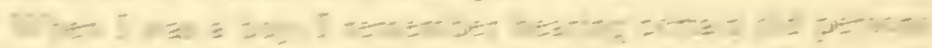

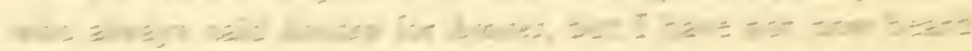

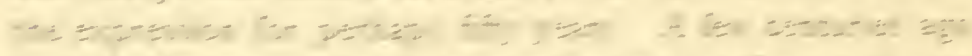

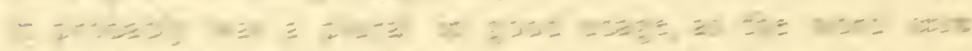

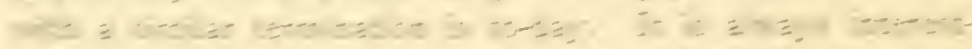

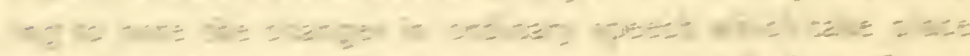

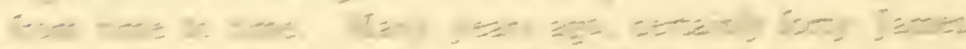

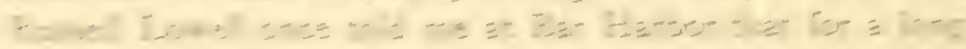

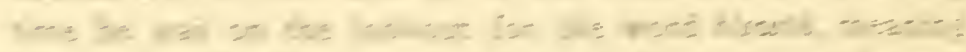

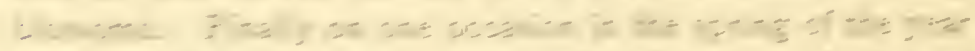

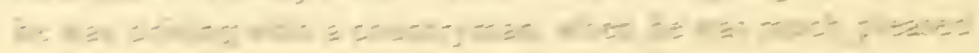


to have his attention called to the blureth of an apple tree in a neighboring orchard. The thrill caused by this word was equalled only by the pleasure of a disciple of Izaak Walton when he feels the bite of a trout jumping at his fly. The word "blowth" is now no longer heard, but three centurics ago it was not uncommon in literature. Lowell himself in his Introduction to "The Biglow Papers," second series (p. xxiii), gives this word with many other similar ones that have lost either their original meaning or their pronunciation.

\section{THE USE OF A P'ILLION.}

FEll persons of the present day in this neighborhood have ever seen a pillion, and fewer still have ever seen one in actual use. It was a leather pad or cushion, put on behind and attached to a man's saddle by straps, on which a woman might ride. In early times pillions were common throughout the country towns of $\mathrm{New}$ England, and particularly the hill towns, but they have long since disappeared. Every farmer that owned a saddle also possessed a pillion; and, in going on horseback for any considerable distance to the store or meeting-house, he often took his wife to ride along with him, she holding on by clasping his waist. In the same way the young men, following the example thus set them, frequently. took their sisters or somebody else's sisters to the singing. school or other gathering; and the tradition has come down that the girls liked this kind of travelling quite as much as their brothers or somebody else's brothers.

During the last ten years I have asked many aged persons in different parts of Middlesex County, if they had ever witnessed this style of riding; and, almost invariably; they have replied, never more than once or twice, and then only when they were children. From these facts, I draw the conclusion that the custom of riding donble disappeared in this part of Massachusetts more than a century ago, though in some other places it may have lingered till a later period. 


\section{THE AGE OF APPLE-TREES.}

ON my place in the village of Groton there are several old apple-trees which seventy-five years ago bore well, and still continue to bear a fair crop of fruit. "While they begin to show the signs of age, they do not seem to be very much larger or taller than they used to be, when I first remember them, though, of course, they are thicker through the butts. Perhaps to my youthful fancy these trees then appeared larger than they really were. I mention the fact here in order to show that apple-trees will continue to bear during a long period of time, probably through a century.

\section{THOMAS BROWNE, DISH-TURNER.}

AT the Essex Registry of Deeds, Salem, there is recorded (Volume II., p. 91), under date of June $17,166_{3}$, the transfer of a six-acre house-lot and a house by William Longley, of Lynn, to Thomas Browne, of "Grawton," who is described as a dish-turner. For a reference to the same transaction, see Deeds (Volume III., p. I26) at the Middlesex Registry, East Cambridge. In early times many articles of household use were made of wood which have since been fashioned in other material. Particularly in the country, wooden bowls, plates, large spoons, etc., were in common use; and men skilled in making them formed a separate trade, often carried on in connection with some other calling.

Many years ago the late Mrs. Pamelia Jane (Bolton | Cartwright) Howe, of Roxbury, daughter of Eliab Going and Dorcas Rogers (Farwell) Bolton, of Groton, gave me a wooden plate made of maple, with an inscription on the bottom, saying that since the year 1756 it had been used by three generations of the Foster family, and that it was sold by auction in IS80. The family lived near Squannacook village, now known as IVest Groton. 


\section{WILD ANIMALS.}

CERTAIN kinds of animals, common in the early days of Groton, have now become extinct, or nearly so, in the neighborhood. Some of them, as enemies of mankind, have been stamped out in a relentless manner, while others have been exterminated by the hunter or the trapper. In other words, they have disappeared before the march of civilization.

A frequent entry in the early town-records is the payment of money for killing wolves. The bounty at first appears to have been ten shillings a head, but later it was considerably less. On November 13, I672, an assessment was made by the Selectmen for raising money to pay some debts, among which was the item: "for pay for a woalfes head to John Nutting o Io o." On February 8, I680, - "The town Rat beeing truly cast $\mathrm{vp}$ by the sellect men to pay for wolues heads the sume is 864 ." Again, on December 29, 1683 , a payment is charged "too Josiah Parker for I wollfs hed and pups O I I," "too Jams Nutin for 2 wolves hed and 3 days I I I," and "too John ffarnworth for I wolf hed 3 dys half I I 3." Other entries of a similar character are found scattered through the town-records of that century.

For sixty years Deer-Reeves were regular officers chosen by the town to protect wild deer. As early as March I, I 742-3, John Longley, Jr., and Obadiah Parker were elected to the position " to Take Care $y^{t} \cdot y^{e}$. Dear be not Destroyed Conterary to ye Law," \&c.; and the office was kept up until the March meeting of ISO2.

Foxes are still found, though gradually decreasing in numbers. While a lad, at different times I have seen them on Broad Meadow during the winter season, when they were tempted by hunger to visit hen-houses or poultry yards. A few years ago, near Snake Hill, I saw unmistakable traces of a bird that had been killed by a fox within a very short time. The late George Sumner Graves, a noted sportsman of Groton, wrote me on November I3, I889, only sixteen days before his 
death, that in his opinion there are not less than twenty-five foxes killed each year within the limits of the town.

According to "A Statement of the Number of Noxious Animals destroyed in each town," made on January 27, 1837, by the Secretary of the Commonwealth (who, by the way, was John P. Bigelow, a native of Groton), fifty-four foxes were killed in this town between May I, I835, and January II, I 837 .

Nore than sixty years ago I remember that the late Asa Shedd Lewis brought into the Brick Store a piece of wood, as large as a man's arm, that had been gnawed through by beavers. Mr. Lewis lived on Chicopee Row ; and the wood, which I saw at the time, was found in the meadow, near Hawtree Brook. See Miss Hill's paper under "Beaver" (p. 78 ). Frank D. Lewis, the present owner of the farm, is a grandson of A. S. Lewis.

The late Zara Patch once told me that his grandfather Jacob Patch once pointed out to him, when a boy, the place near the foot of Rocky Hill, in the easterly part of the town, where when a young man he had seen a bear with some cubs, lying down under a projecting bowlder. His grandfather was born on April 5, I 747. Mr. Patch was a son of Zara and Susanna (Nutting) Patch, and was born at Groton on November 20. 1812. He died there on June I0, 1909, and at the time of his death was the oldest person in town.

In the spring of 1846 the late Eliab Going Bolton gave me the rattle of a rattlesnake, which he had killed some years before on Snake Hill. Besides a "button" at the end, it had twelve rattles, and is now in the possession of the Boston Natural History Society, where it was given on December 9, I 869 .

Muskrats are still common in the meadows, and a great pest to all potato patches on low ground. Woodchucks are also occasionally seen in the fields or on the hills, but in time they will disappear, like many other kinds of animals. Within forty years I have seen a mink on my father's meadow; and occasionally one is killed in the township.

An article appeared in the "Boston Evening Record," 
November 9, I889, under the head of "Good Game Stories," from which the following extract is taken :-

There is good coon country nearer home in Middlesex County. Henry Fletcher of Westford, a great coon and fox hunter, has bagged five coons so far this fall. Other animals besides coons are being killed up in Middlesex. Mr. Carkin, who lives in the village of Graniteville, in Westford, took his gun and went hunting the other day on Snake Hill, close by Sandy pond, in Groton. Snake Hill is a wild, ledgy place, and was once a great resort for rattlesnakes. Mr. Carkin's dog ran an animal into a wall and poked his nose in after him, and pulled it out again quicker than lightning. The dog's nose was full of quills. Mr. Carkin killed the animal, which proved to be a huge hedge-hog. A few days later a Groton hunter killed another hedge-hog on Snake Hill, and he found in the ledges the mouth of a den, which by the "sign" around it seemed to be inhabited by at least 20 of the animals. There are coons in other sections of Middlesex.

In the "Boston Evening Record," October I I, I 890, under the heading of "Seen and Heard," it is said : -

That chosen haunt of the fierce and fretful hedge-hog, Snake Hill, hard by Sandy Pond, in the town of Groton (Groton, Mass.), is reported to have turned out a large fall crop of the sharp-quilled beasts.

\section{DR. WILLIAM DOUGLASS'S SUMMARY.}

MANY plants were brought originally to New England from other countries for their medical virtues, and many were introduced by chance. Some have multiplied so rapidly and grown so plentifully in the fields and by the roadside, that they are now considered common weeds. Wormwood, tansy, chamomile, yarrow, dandelion, burdock, plantain, catnip, and mint, all came here by importation. These foreign plants made their way into the interior, as fast as civilization extended in that direction. Dr. William Douglass, in "A 
Summary, Historical and Political, Of the first Planting, progressive Improvements, and present State of the British Settlements in NORTH AMERICA," first published at Boston (Volume I. in the year I749, and Volume II. in I753), says : -

Near Boston and other great Towns, some Field Plants which accidentally have been imported from Europe, spread much, and are a great Nusance in Pastures, . . . at present they have spread Inland from Boston, about 30 Miles (II. 207).

According to this statement, the pioneers of some of these foreign weeds had reached Groton near the middle of the last century. Dr. Douglass gives another fact about the town which is worth preserving. He says:-

There are some actual Surveys of Extents which ought not to be lost in Oblivion; as for Instance, from Merrimack River due West to Groton Meeting House are I 2 Miles; from Groton Meeting House (as surveyed by Col. Stoddard, Major Fulham, and Mr. Dreight, by Order of the General Assembly) to Northficld Meeting-House IV. I6. d. N. by Compass, are 4 I Mliles and half; from Deerfield MeetingHouse near Connecticut River, a little higher [lower?], to Albany Church upon the West Side of Hudson's River, W. 12 and half d. N. are 57 Miles 20 Rod. From such actual Surveys the publick Roads may be laid out to better Advantage than at present: For Instance, the present Road from Boston to Albany (this is the Road to Monreal in Canada) by Way of Springfield, the Housatonicks, and Kinderhook is about 200 Miles; a new and better Road, but not as yet well improv'd, is via Lancaster and Nichazwog [Petersham] to Sunderland upon Connecticut River 84 Miles, and from Deerfeld a little higher to Albany are 57 Miles, being in all only about 150 Miles (I. 425 note).

Such surveys, as those mentioned in this extract, before the days of railroads, were of more value to the public than they are now; but, as the author says, "they ought not to be lost in Oblivion." 


\section{MOCKING-BIRDS FOUND IN GROTON.}

THE following communication is taken from "The Auk: A Quarterly Journal of Ornithology " (XII. 308, 309) for July, I 895 , and furnishes an interesting fact in connection with the fanna of Groton. For many years the editor of the Historical Series has known that the mocking-bird was seen occasionally in this neighborhood, but he was not aware that the fact had any special significance, or that the bird ever nested here.

Nesting of Mimus polyglottus in Eastern Massachusetts. - On June 3, r895, while walking along a narrow country road in Groton, Massachusetts, my attention was suddenly attracted by the strange sight of a Mockingbird flying across an adjoining field. It alighted on a fence post near by, and, as I turned back to make sure that I had seen aright, my surprise was increased by the appearance of a second one. The two birds flew off together with such an evident air of being mates that I immediately began to look for a nest. The road was bordered on each side by a broad stretch of grassy fields, divided by rail fences; an eighth of a mile away it crossed a much travelled highway, strung along which a dozen houses could be seen; while at about the same distance in the opposite direction was the beginning of a large tract of deciduous woods. Besides these woods, there was hardly a tree anywhere near, save a few small apple-trees by one of the houses and one or two more - stunted, chance-sown seedlings - growing by the roadside. To one of the latter, a few steps away, I directed my search. In a moment I discovered a clumsily built nest a dozen feet from the ground, amid the thick foliage of a branch that overhung the road. I climbed the tree and, though I found the nest empty, I was rewarded by a scolding visit from the birds. When I came again on June I 3 they gave me a still more unfriendly greeting though they were so wary that I obtained only the male to accompany the nest and four half-incubated eggs which I secured.

This locality, which is in the northern part of Middlesex County, hardly six miles south of the New Hampshire boundary, is the most northern point in New England where the Mockingbird has yet been known to breed, and the only one in Massachusetts, east of 
Springfield, where its nest actually has been taken. The only other recorded evidence $I$ can find of the breeding of the species in eastern Massachusetts is based on two families of well grown young, found, one at Arlington (Auk, I, 192), the other at Marshfield (O. \& O. XIV, I44). In each of these cases the birds were not

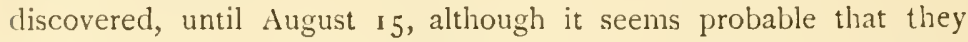
had been bred in the neighborhood.-Charles F. Batchelder, Cambridge, Mass.

\section{LEACH-TUBS.}

DURING my boyhood nearly every family in town had a "leach" standing outdoors within easy distance of the kitchen, which was looked after by the women of the houeshold. It was used for draining water through wood-ashes in order to get lye, a needed ingredient in making soft soap. Sometimes a barrel or hogshead was called into requisition for holding the ashes, but these receptacles were rather temporary, as the lye would soon rot the staves; and I have seen a section of a hollow tree used for the purpose. The best leach-tubs were made of plank, and in the form of an inverted truncated cone or pyramid, with a perforated bottom covered with straw or twigs, letting the liquid percolate into grooves cut in the supporting base in order to conduct it to a pot under the edge. From time to time this receiving vessel was emptied into the soap-fat barrel, which often stood in the woodshed near by; and occasionally a small piece of potash was added to supplement the lye. With some other details not necessary to mention here the product of the mixture was the saponaceous compound known as soft soap. Within the last fifty years these leaching vats have disappeared from this neighborhood, and the ready-made article is brought from the factory to the door of the house, where it is sold for cash or bartered for grease or ashes. The change in such matters is a phase of domestic evolution which is continually going on around us, and yet so gradually that it makes but little impression at the time, and is soon forgotten. 


\section{A SILVER-GRAY FOX.}

Ox May $3 \mathrm{I}, 1907$, the day after the Memorial exercises at Groton, I was driving with the late Colonel T. Lawrence Motley in the easterly part of the town, passing by the Rocky Hill district into the township of Dunstable. Just before we reached the Groton line again toward Pepperell, a large silver-gray fox came out of the sprout land or woods on the easterly side of the road and trotted along very leisurely ahead of us. We reined up the horse and followed the fox slowly for perhaps thirty or forty rods. He did not appear to be at all frightened, and was so large that at first sight I thought he was a wolf, but his brush clinched the matter in regard to the kind of animal. There was no mistake about the tail. In a minute or two the fox left the road and trotted into the woods on the westerly side of the way. We then hastened toward the spot where he had disappeared, not expecting to see him again. When we reached the place, much to our astonishment he had turned around, and was standing agape within twelve or fifteen feet of the road staring at us. $\mathrm{He}$ seemed to be enjoying the situation and was grinning apparently at our surprise. We stopped for a moment and watched him, when I made the remark, What a pity it is that we could not have caught him with a kodak, as he then stood. By this time the fox had seen enough of us, when he deliberately turned round and disappeared in the underbrush and forests.

He was the largest specimen of a fox, and the only one of this variety, that I had ever seen; and Colonel Motley agreed with me fully in regard to the size and the.kind that ever came under his observation.

\section{MINERALS FOUND IN GROTON.}

THE following paper is found, among the manuscripts of the Massachusetts Historical Society, in the first volume of Belknap Papers, marked on the back "Miscellaneous Letters. 
1637 to 1788 ," leaf eleven. According to the indorsement, the paper was written in the spring of 1684 . The writer was Dr. William Avery, a physician of Boston, who was concerned in mining researches, as made in New England more than two hundred years ago; and his correspondent was Robert Boyle, of London, who was much interested in the welfare of the Indians. Eliot dedicated to Boyle the second edition of his translation of the Bible.

Cold Spring lies in the northerly part of Groton, near Reedy Meadow, and is still known by that name. Marcasite, mentioned in the paper, is a sulphide of iron resembling pyrite or conmon iron pyrites in composition but differing in form. For many years bog-ore has been found in that neighborhood, and formerly was worked to a small extent.

In the year I684, the highest court in England declared the charter of the Colony of Massachusetts Bay null and void ; and the allusion in the last paragraph of the postscript is to that anticipated event.

\section{A Note of the mineralls.}

Nō I is only to shew the probabilitie that svch [torn] have bin flvid or liqvid and have had a kind [tom] or concrettion

Nō. 2 is a Red Dvst that coms ovt of the side of a [torn] Som Doe think is a signe of som mettall

Nō. 3 is a marksite that coms ovt of a Narrow long hill and this matter is taken ovt at the top of the hill abovt 3 or 4 foot Deep

Nō. 5 is a svlphvriovs matter lying in veines between the square stones sent the last yeer

Nōm 4 is a marksite or firestone that mr Whorten have sent if that might be a hopefull Signe of mettalls: there is plentie of it - this

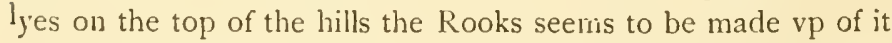

Nō 6 is from the Side of a great hill just by a brook side and was taken almost at the top of the grovnd where is mvch Soft blak Stone that will easily crumble to Dust

This like a shell in the paper Sent by mr whorten only as a Raritie

This Bitvmen or gum is fovnd by the Sea Shore cast up by the water if it may be proffittable we hope to present yov with more of it and also give some fvrther acount of it - at Nantastik enquire of $\mathrm{mr}$ gare or mr Coffin they are inhabitance there or Nantvket 
No 7 is taken ovt of a Roky hill — and if we had not bin prevented wee had Sent more of it

Thes are presented to your Honovr for advice

if any of thes be encrrageing wee shall take care to make Som farther triall, to see what ther is, that lyes Deeper and is more incvrageing. Not Dovbting bvt if as thes faile but if the lord shal please to prosper ovr indevovrs - bvt within a years time to present yovr honovr with Somthing of more worth than any of thes

[Indorsed] A Note of things Sent to mr boyle March $308_{3}$

Postscript

Honovrable $\mathrm{S}^{r}$

wee who have written to yovr honovr for that privilidge from his maj for the encovragement to poor covntriemen that mines might be Discovered here in $\mathrm{N}-\mathrm{E}$ Did it not at al to apropriat the benefit of it to ovr selves for we have pvrposed that if Providence shal make ovr indevovrs profitable to vs : that wee will not be bakward to shew ovr thankfullnes to his majestie for his graciovs favovr to vs in that case

and haveing for this 2 or 3 yeers time bin Diging in a Roky hill at cold Spring at Groten and following a veine of a svlfuriovs markasite 44 foot Right Dovne with ovt one shovl fvll of earth and Now are in a white sparr - a small quantetie of the spa[rr] and of the marcasite we have sent to yovr honovr, and covld be willing if you shall think it may be acsepted that what we have with ovr labovr and cost attained that it might be presented to his majestie as a token of ovr alegience and ovr Desires of his prosperitie and the first frvits of ovr minerall work (before we have made any benefit of it to ovr selves, in hope if the lord continve ovr lives with health peace and libertie that within a few yeer time we shal have somthing of more valve to present him with - it may be it may be [sic] lookt vpon as the 2 hands fvll of water that I mentioned in my last - bvt if it find like acseptance (seeing I have no better) my end will be in som measvre attained.

we have sent al that we have attained knowing that there is som thing good in it tho wee feare not proffitable at present - and if your honovr shal see Cause to cal for it we have taken care with ovr honovred frind who will without faile Dispose of it according to yovr honovrs order

it is Reported by some that there are sedvlovs indevovrs by som ill affected persons: to insence his majestie against vs $\&$ to provok 
him to change ovr govrment, which if they shovld prevaile to Doe it mvst of Nessesitie pvt a stop to this mineral work and we who som of vs have labovred in it this 20 yeers and are bvt Now com to a grovnded hope of ovr Desires of benefit to his majestie and to our Nation also must cease ovr indevovrs in that kind: and ly dovne in Sorrow knowing that the Enemy can Never be able to corntervaile the kings Damage

[Indorsed] a Coppy of a letter to $\mathrm{mr}$ boyle $8_{4}$ conserning

mineralls at Groten

\section{FOUR ARTESIAN WELLS.}

In the autumn of I 886 two Artesian wells were drilled at Groton, under the management of Benjamin Franklin Smith and his brother Charles Greenleaf Smith, of Boston, experts in driving wells. As the details of such matters are so soon forgotten, I will here place on record the following facts, obtained through the courtesy of the Messrs. Smith.

The first well was sunk, on the west side of Farmers' Row, for the Groton School. It was drilled six inches in diameter to the depth of one hundred and eighty-seven feet, at a cost of eight dollars $(\$ 8.00)$ a foot, and was finished in the early part of November, I886, after several months' labor.

The second well was drilled by the same firm on the land of Frank Farnsworth Waters, near the Unitarian Meetinghouse; and the work was begun immediately after the completion of the first one. It was sunk six inches in diameter to the depth of one hundred and sixty-three feet, of which sixty-three were through sand and gravel and one hundred through rock. The cost was seven dollars $(\$ 7.00)$ a foot for drilling through earth, and eight dollars $(\$ 8.00)$ for rock. The daily progress was between four and five feet on an average, and the work was completed in the early part of December. The water is excellent in quality and inexhaustible in quantity, and is pumped up by steam power. The well is estimated to yield a continuous supply of fifty gallons a minute, but it is used only in times of drought. 
A third Artesian well was drilled six inches in diameter on the land of the Honorable IVilliam F. Wharton and sunk to a depth of three hundred and twenty feet without reaching water in any large quantity. With the exception of eight feet of earth near the surface, the drilling went through slate rock and occasional layers of a formation resembling soapstone. Water in small quantities was found at a depth of thirty-five feet, slightly increasing during the next thirty feet, but afterward with no gain in the supply, which was about fifty gallons an hour. The site of the well was westerly from Mr. IVharton's house; and, as soon as it was clear that further drilling was impracticable, another site on the northerly side of his house was chosen. This second well was carried to a depth of one hundred feet without finding water in sufficient quantity. A third well was then begun a short distance easterly from the second onc, and drilled to a depth of thirtyfive feet, when water was obtained in abundance. It is the one now in use to supply the various buildings on the place, and the water is raised by means of a windmill. The well, it is estimated, will yield a daily supply of fifteen thousand gallons.

Work on the project was begun in May, 1894, and ended in August. The contractor was James Starr, formerly a resident of Groton, who has had a large experience in drilling wells; and to his courtesy I am indebted for the facts.

In the autumn of 1895 a fourth Artesian well, six inches in diameter, was drilled by Mr. Starr in the house lot of the late Dr. William B. Warren, on the southerly side of his divelling. It was carried through solid rock one hundred and four feet below the bottom of his old well nineteen feet deep, from which it started, thereby reaching a depth of one hundred and twenty-three feet in all. When water was struck, it came suddenly and copiously, and was of an excellent quality. Work was begun in September, I 896 , and lasted about six weeks.

Artesian wells receive their name from the province of Artois, in France, where they were first bored, and where they have been common for many years. 


\section{SHADE AND ORNAMENTAL TREES.}

Governor Boutwell kindly furnished me with a copy of his paper on "Shade and Ornamental Trees in the Village of Groton," which he read before the Groton Historical Society, on November 8, I894. His familiarity with the neighborhood during three score years, aided by a keen eye for observation and by a retentive memory, rendered him a most competent person to write on the subject. The paper will have an increasing interest, as the years roll by; and it is as follows:-

It will be sixty years the fifth day of March next since I became a resident of Groton, and in no respect has the town been more improved than in the multiplication of trees on the sides of streets and highways, and in the grounds around the dwellings.

In the year 1835 the following streets did not exist, viz.: High Street, Pleasant Street, Champney Street, Willow Dale, Court Street, and Station Avenue. The trees upon those streets have been planted from time to time as the streets were establshed. In 1835 there were no trees upon the Common by the Chaplin school-house, and with the exception of an elm by the Mansfield house there were none on Hollis Street above the cottage now occupied by Mrs. Simeon Ames.

The old graveyard was bare of trees until 1846. In that year I was elected chairman of the board of selectmen, and while in office I directed Eliab G. Bolton, who had usually mowed the weeds and grass, to save every growth that promised to make a tree. From that order have come the trees now growing in the cemetery, with the exception of a small number that have been set by friends of persons buried in the grounds.

Going northward on the road towards Hollis and Dunstable there were no trees unless the large and beautiful maple by the Champney house may have been an exception. The elms by the Dr. Chaplin house [now Mr. Woolley's] had a very considerable size at a time as early as I have any recollection of them.

There were also one or two elms of considerable size in the rear of the house now owned by Mrs. George Blood, but then owned by Daniel Shattuck.

Passing on to Main Street, the first tree of notable size was a 
large ash that stood at the corner of Court and Main Streets, and near the Stevens store. It was then aged, and many years ago it was cut ,down.

Two or three small elms stood in front of the Stevens store, and the house now owned by Dr. Warren. The very considerable elm at the foot of Colonel Needham's grounds had not been set. Some years later, probably between 1840 and 1850 , the building ${ }^{1}$ afterward known as Liberty Hall was moved from the low land at the foot of Willow Dale to the site of the Stevens store. In moving the building it was drawn over the young elm, which yielded to the weight without any apparent injury.

The elm that stands near the cottage on the premises of $\mathrm{Wm}$. A. Lawrence, known as the Dr. Amos B. Bancroft place, was a young tree, a volunteer growing in the old fence.

On the other side of the street and in front of the Hollingsworth place, now owned by Frank Lawrence Blood, are several large trees that were volunteers and owed their continued existence to the fact that they were protected by the fence in which they were growing. The fence was irregular, as are the trees. One of them is on the street side of the fence, two or three are in the Hollingsworth grounds, and one or two are in the lot of Mrs. Ames. About the year I 840 the county commissioners changed the street lines, and the tree by the cottage became private property, and several of the trees on the opposite side of the street fell inside of the street lines.

Following the line of the street on the westerly side there was not a tree of any considerable size between the one by the cottage, and the elm-trees in the land of Charles Gerrish and to the southeast of the house of the Misses Warren.

From the cottage to the house owned by Mrs. Blitz, widow of

1 The building was moved in Novenber, 1844 , to the corner of Main and Court Streets; and during the process it stood for one night over an elm sapling at the junction of Mlain and Hollis Streets, bending it to the ground and giving it a permanent list to the westward. The tree was set out a few years before by Curtis Shepley, a well-known citizen; and I remember when, together with other lads, we watched the transplanting. After the job was finished, he said, "There, boys, Curt. Shepley has done one good thing, even if he has never done another." This was seventy years ago, though now it seems only a short time. The tree stands near the site of the old town-pump which has disappeared since the introduction of water; and I never pass it without thinking of some of these facts. The elm still has an inclination to the westward, and is an unrecognized memorial to the foresight of a kind-hearted native of the town. Mr. Shepley was a son of Wilder and Phebe Shepley; and he died on March 26, 1845, at the age of 55 years, 9 months, and 3 days. $-G$. 
Signor Blitz, then the property of Elijah Whiton, there was neither tree nor building. About the year 1836 , the entire square, including the ground where the railway station stands, was sold at auction. It was bought by Dr. Bancroft, senior. The price was $\$ 125$ or \$1 35 per acre, and it was called the Lewis lot.

There was not a tree between the entrance to Mr. Geo. D. Brigham's place, then the property of his father, and the shop on the northerly side of the Dix building, then a store kept by Benj. P. Dix. The property was owned by Jonathan Loring, whose house stood near where the high school building now stands. His workshop, then unused, stood near to Bruce's drug store and a few feet to the south. Mr. Loring and his wife were not friendly to trees.

Turning to the north end of the street, I cannot recall the fact of the existence of a single tree north of the brook between those near the house of Mrs. Geo. Blood and the trees near the junction of Court Street and Main Street. The house of Dr. Amos Bancroft stood on what is now my lawn, and somewhere near the centre. In front and within the street limits, after the alteration of the line, there was a large horse-chestnut tree, and also an elm of very considerable size. The elm was cut down December 2, 1859 , and the horsechestnut was removed into the yard of Mr. Charles Bancroft somewhat later, when the grade of the sidewalk was lowered.

The trees about my house have been set since $185^{\circ}$. It is my impression that the trees in the yard in front of the house of Mrs. Eliel Shumway were set before $\mathrm{I}_{3} \circ$, and by Mr. Luther Lawrence. who built the house.

In the year 1835 the trees in the grounds of the estate of Dr. Samuel A. Green had then been recently set by his father, Dr. Joshua Green. As to the tree now standing in the south-west corner of the lot and near the brick store, I have a distinct recollection of a statement which I received from Dr. Joshua Green, viz., that he brought that tree to his home in his chaise. At about the same time the tivo trees that stood in front of the Henry Woods honse were set. In 184 r they were so small that I dug around them in the hope of promoting their growth. The fire which destroyed the house, on July 8. I 892 , was a serious injury to the trees; and since then they have been cut down.

The next trees were the elms in the yard of the Boynton place, now owned by Mr. Charles Gerrish. The trees in the street are of later origin. 'The next tree is the elm near the well in the corner of the lawn of Mr. Bigelow, then the property of Mr. John Peabody. 
In $18_{35}$ the Common in front of the First Parish meetinghouse had not been fenced in, but the row of elms on the margin of the street had been planted at the same time that a double row was planted on that side of the street to the house now owned by Mr. John E. Hodgman. Most of the second row have disappeared, but a few of them remain in front of the Academy buildings.

These trees were set by John G. Park and Benjamin Prescott, and the work was the earliest systematic attempt to improve the appearance of the town by the growth of shade and ornamental trees. To Mr. Park I am indebted for the statement that Prescott procured the trees from a farmer in Brookline, New Hampshire, and paid for them with young apple-trees from his father's nursery. 'The elms in the park now called Prescott Square were set at the same time, and by the same persons. In front of the Judge Prescott place, more recently called the Fosdick place, there were two large elms and a black-walnut tree. One elm and the walnut remain, but at a time previous to 1840 , the other elm was blown over. ${ }^{1}$

The magnificent elms in front of the Susan Prescott place, now owned by Parker Fletcher, and on both sides of the street and forming an arch over it, were then of great size, as were the elms and black-ash trees further along on the Boston road, and near the residences of George Prescott and Eugene O. Collier.

In front of the residence of Stuart J. Park, now the residence of Mr. Frank F. Woods, there was a gnarled oak that antedated in its beginning the settlement of the town probably, and, vigorous as it was. it would have withstood the storms of another century. It marked the birthplace of Col. William Prescott, and its destruction was only less than a public calamity.

There were elm-trees and one or two mountain-ash trees in front of the Academy building now occupied by Mrs. Sibley, and there were elm-trees by the other Acadenuy house, now occupied by Rev. Dr. Young. The mountain-ash trees have disappeared, but the elms can be distinguished readily from their size and marks of age.

The double row of willows by the road across Broad Meadow were set between the years 1846 and $185 \mathrm{r}$. In those years the board of selectmen consisted of Joshua Gilson, Pelatiah Fletcher, and myself. The railing against the ditches by the roadside had become so im-

I This happened, probably, in the year $1 \$_{3} 6$, and during the same gale Mr. Osborn's house, then in process of framing just across the way, was blown down. - G. 
paired that a new railing was required. Mr. Joseph Rugg was employed to build the new railing, and he was directed to set the willows, but with the only thought that they might be a substitute for a railing. That end they answer, but they also constitute an avenue of shade and beauty.

The new cemetery was laid out in the year 1847 , and thus a bare and barren hill was transformed into a park, made attractive even in the evidences of death and change by the beauty of the trees that have been planted along its ways and avenues.

In the year 1835 the thought of planting trees by the highway, or of preserving those that might spring up, had not taken possession of the public mind.

In the last third of a century a good deal has been accomplished in both particulars; but there is much opportunity for better things, especially in the protection and the preservation of the trees that we now have. Within the last ten years the telegraph and telephone companies have done irreparable damage by the mutilation of trees by the roadsides, sometimes within the road limits and sometimes on private property.

Serious injury has been done by abutters who have cut trees, and destroyed the lesser growth upon the margins of the roads, and often to the damage of their own estates.

These proceedings should be arrested by the rigid enforcement of the law, which is ample for the purpose. I cannot doubt that the beauty of the town has been more improved in these sixty years by the planting and growth of trees than it has been by the erection of new buildings, and the repair and adornment of old ones.

\section{BOG-ORE.}

BOG-ORE, sometimes called swamp-ore, was found in Groton by the earliest settlers of the town, and to a small extent was worked by them. In the printed edition of the Early Records the following entry is found:-

Groton: May $y^{\mathrm{e}} 2 \mathrm{I}^{\text {th }}$ day: $\mathrm{I} 688$

at $\mathrm{y}^{\mathrm{r}}$ anueal towne meeting the Inhabatan of this towne leed then by the maior uoat grant for the incoregment of such men as will set up loran works at masabog pond; that thay shall have $y^{e}$ ues $\&$ improument of the wonds and timbr 
$y^{t}$ is now common one the est sid of uncuttanaset brook and so to nashua riuer and groton line est ward \& south ward to good man greens masobog medow for ther incorigment in $\mathrm{y}^{\mathrm{e}} \mathrm{s}^{\mathrm{d}}$ worke allways prouided $y^{e}$ inhabatnts of $y^{e}$ afere $s^{d}$ towne resarue to $y^{m}$ selus the liberty to cut the wood for $\mathrm{y}^{\mathrm{e}}$ ues of $\mathrm{s}^{\mathrm{d}}$ works and also for carting of $\mathrm{y}^{\mathrm{e}} \mathrm{s}^{\mathrm{d}}$ wood or coall prouided $\mathrm{y}^{\mathrm{e}} \mathrm{s}^{\mathrm{d}}$ workes be up or seteng up betwen this day and the $2 \mathrm{r}^{\text {th }}$ day of may next; no man inhabiting with in $\mathrm{y}^{\mathrm{e}} \mathrm{s}^{\mathrm{d}}$ town to be hindred from wodo or timbr for his one ues

(Pp. 97, 98.)

Atest

Josiah Parker Clurke

A sworn declaration of John Lowwell and Thomas Blanchard, both of Dunstable, is recorded in the Middlesex Registry of Deeds at East Cambridge (XVIII. 488, 489, ) setting forth the fact that they were at Massapoag in Groton, on the twentieth day of May, I689, and did "help both to dige for $\&$ to sett up some part of an Iron Worke." From this record it appears that the vote of the town had its desired effect.

"The Sledges" is the name of a meadow lying northeast of Reedy Meadow, and is mentioned in the early records of the town. Mr. Butler, in his History (p. 273, note), says:

"This word seems to signify strips of meadow, or parcels of low lands, abounding in iron ore."

About the year I 768 Jabez Keep, of Westford, established a forge and bloomery on the site of Jonas Prescott's first gristmill in Harvard, where ore from the Groton swamps was smelted. "'His son Jabez and his grandson Jabez, 'bloomers,' succeeded him in the business. The latter probably returned to Westford and carried on the same business there" : so Mr. Nourse, the historian of Harvard, writes me.

Just before the town of Lowell was incorporated, but during the period when its rapid growth was assured, an ironfoundry was established at North Chelmsford, where bog-ore was smelted. The supply was furnished largely from towns in that neighborhood, and it was carried to the foundry for the most part by farmers with their own teams. A considerable amount of native ore was dug from various meadows in Groton, principally in the eastern part of the town, and taken there to be smelted; and in this way the farmers during dull 
times would obtain a little ready money. This foundry is the forerunner of the Chelmsford Foundry Company which is still doing business.

\section{A BAPTISTERY.}

A BAPTIST Society was organized at Groton on December 5. I $\$ 32$, and the Reverend Amasa Sanderson was the first minister. Captain Josiah Clark, one of the members, generously gave them the use of a commodious hall in the third story of a house at the south corner of Main Street and Broad Meadow Road. About this time a baptistery was made by digging out and damming up a small brook, which was used during a few years by the Society for baptismal purposes. It was in the neighborhood of Captain Clark's dwelling, and on his land, situated within five rods of the Break-Neck Road and just south of that highway. The little stream soon crosses Common Street and finds its way into Nod Brook. The use of this place was given up by the Society many years ago, when they went, as occasion required, to the Nashua River to perform the rite, and until a baptistery was made in their church. The remains of the dam and excavation at this site are distinctly visible, though there is now much undergrowth in the immediate vicinity; and a good-sized elm marks the spot.

A place so hallowed in former years by the affections of even a small body of Christians, deserves the record of these few lines.

\section{THE GEOGRAPHY OF GROTON.}

IN the "Transactions of the Massachusetts Society for Promoting Agriculture" (New Series, Volume I., Part II.), published in the year I 859 , there appears an "Agricultural Survey of Middlesex County," which contains a few items of sufficient local interest to be reprinted. The paper, written by Dr. Joseph Reynolds, a son-in-law of Dr. Oliver Prescott, 
Jr., of Groton, supplements an article entitled "The Geography of Groton," in this volume. After speaking of the general direction of the rivers and streams in the County, the writer goes on to say:-

As we go west from the Merrimac, along the northerly line of the county, we enter the valley of the Nashua. This is a considerable river, and flows through a beautiful section of country. One branch of it rises in New Hampshire, and another in Worcester County. It enters Middlesex from Lancaster, in Worcester. It divides the easterly part of Shirley from Groton; then crossing the western part of Groton, it becomes, for a space, the dividing line between Groton and Pepperell; then entering Pepperell. for a mile or two, it divides that town from Dunstable. It empties into the Merrimac at Nashua, N. H. Its course, after it enters Middlesex, is north by east. It is a rapid stream, and furnishes abundant water-power throughout its whole course, which is improved in Fitchburg, Lancaster, Shirley, Groton, Pepperell, and especially in Nashua, where it furnishes the principal motive power for the large manufacturing establishments of that flourishing city. The soil in the valley of the Nashua is, in general, good. The hills which form this valley, especially on the western side, are many of them broken and abrupt. They yield excellent pasturage. The lower levels, bordering on the river, furnish fertile'mowing lands. There is but little intervale land on the Nashua after it enters the county, and no wet meadows. The first affluent of the Nashua from the west, is the Nissitisset, a short stream, which rises in Poponipos [Potanipas] Pond, in Brookline, N. H. This stream enters Pepperell on its northern line, and passing through the town in a southeasterly direction, reaches the Nashua just above the point where it becomes the boundary between Pepperell and Dunstable. This river is about Io miles in length, and affords good water-power at several points in its course. A few miles to the southwest we find the Squannacook, which is the most important affluent of the Nashua. This river rises in the hills in Ashby, and crossing Townsend in an easterly direction, it turns more to the southeast, and pursues a winding course between the northerly part of Shirley and Groton, and enters the Nashua nearly at right angles, about two miles northwest of Groton Junction [now Ayer]. East of the Nashua is Salmon Brook, which rises in Whitney's Pond, in Groton, and passing through Massapoag Pond, runs a northerly course through the town of Dunstable, and reaches the Nashua before its entrance into the Merrimac. The valley of the Nashua includes, 
in the county, the towns of Dunstable, Groton, Shirley, Pepperell, Townsend, and Ashby; and contains some of the best lands in the county. Some of the farms on the slaty soils of Groton, Pepperell, and Townsend are under high cultivation, and yield abundant crops (pp. $\left.16_{2}, 16_{3}\right)$.

Under the heading of "Geology of the County" Dr. Reynolds writes : -

A range of mica-slate extends across the county, through the towns of Shirley, Groton, Pepperell, and Townsend. It is also found in Dracut and Lowell (p. I 7 I).

Steatite, or soapstone, is found in Groton. It has been worked to some extent. But it is said not to be as easy to work as in some localities, owing to the presence of silex (p. I72).

In connection with the last extract, see an article entitled "The Soapstone Quarry." Professor Edward Hitchcock, in his "Report on the Geology, Mineralogy, Botany, and Zoology of Massachusetts" (Amherst, I833), says:-

In Groton is a bed of soapstone on which considerable labor has been expended. Its width appears to be 10 or $\mathbf{2} 2$ feet, and it descends into the earth towards the southeast; dipping about $30^{\circ}$, and lying between layers of mica slate. It is not of the best quality, being somewhat too hard ; yet its proximity to Boston, Newburyport, and Salem, will probably render it an object of importance (p. 32 ).

\section{HARD COAL.}

ANTHRACITE COAL for heating a dwelling-house was first used in Groton by Aaron Perkins nearly seventy years ago. It was before the year IS45, at which time the Fitchburg Railroad was built through the southern part of the town. According to my recollection, he used it in a grate to warm his keeping-room. It was brought from Boston in one of the Groton baggage-wagons ; and, of course, the quantity was small. Mr. Perkins lived on the east side of Hollis Street, near the Brook.

Governor Boutwell once told me that Mr. Woods had previously used hard coal for heating his store. 


\section{TALLOW DIPS.}

IN early times, throughout New England, tallow dips were commonly used for purposes of domestic lighting, as their cost was so small. Beef tallow was tried out in a big iron kettle hanging on a crane in the fireplace; and, while the fat was still hot, a piece of wick-yarn about ten inches long when doubled, was held by the loop in the middle, and dipped in the tallow. It was then hung over a stick and allowed to cool and harden. When ready it was dipped again, and so on, until it had grown to the proper size. Often a rude frame was used, holding a number of wicks, which were dipped in rotation, the first candle being ready for a second dip by the time that the others had passed through the same process. In order to make the tallow firmer and harder, sometimes bayberry wax was put into the kettle and melted with the fat. Owing to better methods of lighting, and to the cheapness of kerosene, the use of tallow dips has now entirely disappeared from the economy of house-keeping. By a later method these dips were superseded to a great extent by candles run in a mould.

\section{THE PUBLIC WELL.}

THE following facts concerning the public well in the village were furnished mainly by Colonel Daniel Needham, and are of interest. It was through his enterprise and generosity that the well was dug, and for his services in the matter the public owes him a debt of lasting gratitude. The town pump is now so much of a local institution that any details connected with its history are worthy of preservation.

The well is situated near the foot of Colonel Needham's lawn, at the junction of Main and Hollis Streets, and was dug during the summer of 1867 , a remarkably dry season. The cost of sinking the well, independently of the stone cover and the stone trough, was more than five hundred dollars; and of this sum Colonel Needham paid six-tenths, and Ezekiel H. Higgins, Richard Pinckney Joy, Dr. Norman Smith, and 
Willian Jewett Boynton each paid one-tenth. Of these men now there are no survivors.

The depth of the well is twenty-eight feet: the chamber or reservoir at the bottom is large and irregular, and seems to be in solid rock, although the water drips continually from the sides, showing the existence of numerous seams which are imperceptible to the naked eye. The first eight feet were excavated by picks and spades, and the remaining portion was blasted out with powder. The blasting was done under the supervision of John Simonds, and no accident occurred as the result of this part of the work, although there were on an average three blasts daily during much of the time. When the springs are full, the depth of water measures about tiventy feet, but during a drought this is reduced to four feet, more or less. The water is very cold and clear, and excellent for drinking purposes, and is used the year round by many households in the neighborhood, who have no other source of supply. In dry seasons more than thirty families are dependent upon the well for their water. The stone cover and trough were placed at the expense of Colonel Needham.

The elm overshadowing the pump, also, has a history which is worth saving. It was set out many years ago by Curtis Shepley, who is still remembered by some of the older people of the town. In November, I 844, a large building was moved from Hollis Street to the corner of Main and Court Streets, and became known as Liberty Hall. During the removal this structure remained one night over the small tree, pressing it to the ground. On the next day, after the building had passed along, the elm righted itself and has stood there ever since, though it still has a marked inclination or list to the westward, as the direct result of the harsh treatment it received more than sixty-five years ago. Hollis Street, where it branches off from Main Street at this point, according to the North Star, runs very nearly north and south.

The use of the public well was superseded by the introduction of water on the part of the Groton Water Company, incorporated by the Legislature on May 5, i\$97. Colonel Needham died on February 20, 1895. 


\section{HEIGHT OF SOME GROTON HILLS.}

DURING the summer of I 887 a party of engineers employed by the United States Geological Survey perambulated the town of Groton and its neighborhood, and took the direction of the roads and the elevation of the hills, as a part of the topographical survey of the State, which was begun some years previously. They also laid down on their charts the brooks and ponds, and even the dwelling-houses along the roads. From time to time the result of their labors has been printed at Washington, on sheets or maps, under the authority of the Department of the Interior, which is conducting the work of the Geological Survey. Each sheet contains a group of towns, though without indicating their boundary lines, and each sheet is named after some central or prominent town in the group. The altitudes are shown by contour intervals of twenty feet, so that the various heights are represented within that distance.

The Groton Sheet contains the following towns, which are here given in their geographical order: Leominster, Lancaster, Harvard, Littleton, Lunenburg, Shirley, Ayer, Groton, Townsend, Pepperell, and Dunstable, in Massachusetts, and Mason, Brookline, Hollis, and Nashua, in New Hampshire. Through the courtesy of Marcus Baker, Esq., who is connected with the Division of Geography at Washington, I am enabled to give the exact height of the prominent hills in Groton, as follows:-

Chestnut Hills, 544 feet; Indian Hills, 524; Gibbet Hill 5 I6; Prospect Hill, 503 ; Snake Hill, 497 ; The Throne, 484; Brown Loaf, 448; Barralock Hill (north of Baddacook P'ond), 422 ; a hill south of Wattle's Pond, 412; and a hill west of the southerly end of Baddacook Pond, 352 feet. Nonacoicus Hill in Ayer is 393 feet high; a hill, near Shirley Village, lying in a northwesterly direction, $44 \mathrm{I}$ feet; and a hill, perhaps two hundred rods west of Shirley Common, 463 feet. The measurement of these altitudes is taken from mean tide on the coast line.

\subsection{8}




\section{THE GROWTH OF TREES.}

MANY years ago I set out some small trees in my father's yard, and at the time I jotted down the date in a current copy of the Old Farmer's Almanac. They consisted of a few elmis, maples, and ash-trees; and at that time not one of them had more than two years' growth. According to the record in the almanac, they were transplanted on May 3, IS52; and, after a period of forty-five years, I noted the size of the trunks of the largest. The measurements of these trees were taken by me on July 6, 1897; and at a height of four feet from the ground they gave a circumference as follows:-

An elm, six feet two inches; another elm, five feet six inches; an ash, five feet six inches; a maple, five feet three inches; and another ash, four feet six inches. The first elm noted in this paragraph was struck by lightning on Sunday, Jurie 1 3, is97, but fortunately was not damaged to any great extent.

Every tree in my front yard - and there is a large variety of kinds - was set out by my father during the last eighty years. The elm which stands in the southwest corner of the yard, at a height of four feet from the ground, has a circumference of ten feet and three inches; and another elm at the same height has a circumference of eleven feet and six inches. A third tree of a different variety (Ulmus fulia), standing in the same line as the other two, near Mrs. Shumway's fence, has a circumference of seven feet eight inches. This seedling was given to me about seventy years ago by the late Honorable John Boynton, when it was not more than two inches in height, though it was at first set out elsewhere.

Many years ago Mrs. Anna (Parker) Dodge told me that the ash (Fraximus) standing on the westerly side of the road, perhaps twenty rods beyond the stone which marks the site of the first Meeting-house in Groton, was set out by her father when she was a very small girl. The tree is still sound, and at the butt, four feet from the ground, has a circumference of exactly eight feet. In comparison with many other trees the ash is of slow growth. Mrs. Dodge was born on October $2 S$. I Sor, and died in Boston, on November 4, ISSS. 


\section{MOUNT WACHUSETT.}

IT may seem somewhat out of place to put Wachusett in this list of Groton names, but the mountain, though miles away, is so conspicuous an object and so familiar to every resident of the town, that $I$ include it in my scheme.

The earliest allusion to the Wachusett Mountain is found in Governor John Winthrop's Journal, - usually called his History of New England, - where the writer gives an account of a reconnoitring trip made by himself and some others, on January 27, 163I-2. The party followed up the banks of the Charles River to a distance of about "eight miles above Watertown," which brought them within the present limits of Waltham. The Governor describes with some minuteness the main features of the country, and mentions the names given by them to several places and points of interest along the way. Beaver Brook in Waltham was christened at that time, and the name has clung to the stream for nearly three hundred years. Mount Feake, standing near the Charles River, then also received the name which it still bears. Winthrop says :-

On the west side of Mount Feake, they went up a very high rock, from whence they might see all over Neipnett, and a very high hill due west, about forty miles off, and to the N. W. the high hills by Merrimack, above sixty miles off.

Without question the "very high hill" seen from this point was the Wachusett Mountain, the highest elevation in Massachusetts, east of the Connecticut River, and at that time, not known to the English by any name. "Neipnett" was another form of Nipmuck, which embraced a large territory lying in the southern part of Central Massachusetts, and extending even into the present limits of Connecticut. The "Nipmuck country" is an expression often found in the early history of New England, but its boundaries were necessarily very indefinite. "The high hills by Merrimack" were perhaps those, east of the Grand Monadnock, now situated in the townships of New Ipswich, Temple, Peterborough, Lyndeborough, and Goffs- 
town, New Hampshire. If seen from a great distance, these separate hills appear to run into one continuous range extending to the Merrimack River.

The next reference to the Wachusett Mountain is also found in Winthrop's Journal, under the date of March 7, I643-4, where the writer speaks of "two sachems near the great hill to the west called Wachusett," showing that it was then known to the English by the present name.

The word "Wachusett" is of Indian origin, and signifies near the hill or monntain. "Wadchu" in the Indian language means hill or mountain, and the affix "sett" means near or in the neighborhood of. The Indians of course applied the word to the region, but the early settlers soon restricted its meaning to the mountain itself. The name of the Commonwealth is substantially the same word, with the prefixed adjective "Massa," which means great. In the course of time, with the natural elision of syllables used in speech, the word has become "Massachusetts." The same adjective is found in the composition of "Massapaug," well known in Groton as the name of a pond near its eastern boundary. "Paug" is the Indian word for pond; so that "Massapaug" in the Indian tongue means great pond; and "Massapaug Pond" is a duplicated expression.

The Indians had no written language, and the early settlers took the geographical names of the country, by sound, and wrote them down accordingly, without knowing their meaning. This was phonetic spelling, pure and simple, and explains the diversified orthography of Indian words which is so common. With an unwritten language the Indians themselves had no proper standard of pronunciation; and their own usage, therefore, in regard to the same words often varied at different times. A peculiarity of their language was that the geographical names, as applied by them to hills, mountains, ponds, rivers, etc., were common nouns and had a meaning, but the same words, when used by the English, in the course of time became proper nouns and lost their original significance.

In "A Dictionary of Altitudes in the United States" pub- 
lished by the Department of the Interior in the "Bulletin of the United States Geological Survey, No. 5" (Washington, I 884 ), page 136 , the height of Wachusett Mountain is given, on the authority of Professor Arnold Guyot, as 2,018 feet.

\section{THE INTRODUCTION OF THE TOMATO.}

THE tomato plant (Lycopersicum esculentum), now so common in every vegetable garden, was first introduced into Groton about the year 1840 . The young plants, sent to Dr. Joshua Green by William Lawrence, Esq., of Boston, were brought to this town by Aaron Corey, a well-known stage-coach driver of that period, who also acted in the capacity of a modern expressman. They were set out by Eliab Going Bolton, an experienced gardener, who watched them with great care during their growth. I remember distinctly with what curiosity they were regarded by persons interested in such matters; and how the fruit, as it ripened, was carefully distributed in the neighborhood for trial and judgment.

According to my recollection, the verdict at first was an unfavorable one; but this has long since been set aside, and a later tribunal has decreed otherwise. It has decided that the tomato stands on the border-line of necessity, and has come to stay.

\section{DATES OF LOCAL INTEREST.}

THE town of Groton first appears on any map in that of New England, which is printed in the Reverend IVilliam Hubbard's "Narrative of the Troubles with the Indians" (Boston, 1677).

The town-clock in the steeple of the Unitarian Meetinghouse was made by James Ridgeway, and placed in the tower sometime during the spring of 1809 . It was paid for in part by the town and in part by private subscriptions. Mr. Ridgeway was a silver-smith and a clock-maker, who during 
the war with England (I812-ISI5) carried on a large business in this neighborhood. He afterward removed to Keene, New Hampshire, where he lived for many years. His shop was situated on Main Street, nearly opposite to the Groton Inn, but it disappeared a long time ago.

The clock in the tower of the Baptist Meeting-house was made by the E. Howard Watch and Clock Company, Boston, and was first put in running order between three and four o'clock, Thursday afternoon, November i 8, I897. Henry $1 \mathrm{Wm}$. Whiting did the carpentry, before the placing of the timepiece in position.

A telegraph office in Groton was opened on Saturday, March 20, ISSO; and the first message along its wires was sent to Nashua, N. H. A night operator was appointed in the early part of March, I903.

A telephone office was first opened on Friday, April 24, I $S S I$, in the building at the south corner of Main Street and Station Avenue. It still remains there, but not in the same part of the building.

The reservoir of the Water Company on Gibbet Hill was filled with water for the first time on Monday, November 29, I 897.

The double track on the Worcester and Nashua Railroad, between Groton and Ayer, was opened for traffic on Monday, December 2, 1907, when the first train left Groton at 12 o'clock, noon. The double track from Groton to Pepperell was opened on October I, I9I I.

This road was opened originally for regular business through its entire length on December I 8 , I 848 , though the section from Groton Junction, now Ayer, to Clinton had been previously opened on July 3,1848 , and from Clinton to Worcester on November 22, of the same year.

The first train over the straightened track near the station was run on Thursday noon, August is, 1910.

The new station in the village was first used on March I, 19I I.

The electric light was introduced by the town of Groton on November 20, 1909. 


\section{GLACIAL STRIATION.}

NATURE was the first historian in the world, and her subject was physical geography. She was not a rapid writer, as it took ages upon ages for her to form her characters which modern science has taught us how to read. She never would have been a successful editor of a daily newspaper, who is expected to write a learned leader for each issue of his paper. During the glacial period while New England was covered with ice, Nature sharpened her pen and took notes. When the ice melted, she had left messages on the rocks and in the mountains which are as legible to-day as the pages of Herodotus or other classic historians.

I am led to make these remarks as some notes of her work may still be found by the wayside on the old road to Ayer. Soon after passing Sumner Graves's house, - as laid down on the map at the end of Mr. Butler's History, - and going down the hill, toward Flanagan's Crossing, a large rock or ledge crops out on the right-hand side of the way, nearly opposite to the granite quarry. On the surface of this rock are the traces of some beautiful glacial striation together with the smoothing process caused by the rubbing of stones on the surface. The general direction of these grooves is from the north-west to the south-east.

An old Grotonian who had sailed out of New Bedford harbor in a whaler once told me that the outcropping of this ledge on the surface always reminded him of a whale's back at sea.

\section{WILD DEER.}

Is recent years by legislative enactment the Commonwealth has thrown its protecting arm around wild deer; and consequently within the limits of the State this breed of animals has increased in a prolific manner. Twenty years ago in this neighborhood a deer roaming through the meadows or feeding in the pastures was a sight never witnessed, while to-day herds of considerable numbers are seen at intervals. Miss 
Elizabeth S. Hill tells me that she has counted eleven deer, including bucks, does, and fawns in a herd at one time, though they were so scattered about that they could not be taken with a kodak. She tells me furthermore that eighteen deer and twenty-three deer have been seen at one time by others; and that she sees almost daily two does and two fawns.

I give below certain items taken from the Groton Historical Series of different dates, which relate to the appearance of deer in Groton.

\section{A WILD DEER IN GROTON.}

IVITHin the past week a wild deer has been seen several times in Groton and some of the neighboring towns. He has evidently got astray from his own kindred, and it is hoped that he will not be killed by some ambitious sportsman.

"Boston Evening Journal," August 20, 1892.

\section{WILD DEER.}

Is The Journal of the 2 oth the presence of a wild deer in the town of Groton was noted as a remarkable occurrence. It has since been learned that Mr. John H. Whitcomb of Ayer saw in that town on the 28 th of August a red deer of about ${ }_{5} 50$ pounds in weight. Its antlers were in velvet, having one prong each, and they were about a yard long. Mr. Whitcomb was some 40 yards off when he first saw the deer, but a few minutes later when the animal, approaching a building, became so frightened as to turn and pass the other way, it came within five or six yards of the observer. It is said that a deer was recently seen swimming a lake in Ashburnham. Whether this is the same deer or whether there are several in the woods around the vicinity of Groton is not known. Perhaps some hunter can give information on that point.

"Boston Morning Journal, September io, 1 \$92.

According to the testimony of some of the oldest inhabitants of Groton, this is, probably, the only wild deer seen within the limits of the town during the present century. The local newspapers report that deer have been seen at several places in New Hampshire, where they have not been found for a long period. 


\section{WILD DEER.}

Mosely Gilsox, who lives on the Lowell Road, about half a mile from the First Parish Meeting-house, tells me that in the year I 894 , late in the summer or early in the autumn, his wife saw a wild deer on the easterly side of Gibbet Hill, near his house; and that a few days later his hired man saw one, presumably the same deer, in the meadow opposite to his house.

IVithin a few years deer have been seen at different times in the northern part of Middlesex County, and in the southern part of New Hampshire, showing the good effect of the game laws as applied to that beautiful creature.

\section{WILD DEER.}

DURING the year I 897 wild deer were seen in Dunstable Tyngsboro and Chelmsford, and I have talked with various persons who saw them. Since June 8, deer have been seen in Groton on three different occasions. These repeated instances of their appearance in the northern part of this Commonwealth in modern times show their natural increase, due, doubtless, to the protection they receive from the State of New Hampshire, whence they migrate over the boundary line, and to the further protection here given.

\section{WILD DEER.}

Or June 8, 1897 , rather early in the morning, Wheeler Wilson Ames, who lives in the Rocky Hill School District of Groton, saw a deer feeding in the meadow in front of the Shattuck homestead, a short distance southeasterly from Martin's Pond. On being discovered the deer ran and disappeared over the northern slope of Gibbet Hill, and soon afterward was seen in the outskirts of the village heading for the Four Corners below the soapstone quarry. 


\section{"THE NECK."}

In the town-records, as early as February 17 , I670, a reference is made "to the neck upon the riuer." This is an allusion to a peninsula that once belonged to Amos Farnsworth's farm. It was formed by a long bend in the Nashua River,- perhaps a hundred and thirty rods around,- and joined to the main land by a neck, probably not more than thirty rods wide. At a period near the middle of the last century, very likely during a January thaw or a spring freshet, it was entirely severed from the farm, by the river's breaking through the neck, thus leaving an island of perhaps twenty acres, now partially covered with a growth of pines. The late Honorable Claudius Buchanan Farnsworth, of Pawtucket, Rhode Island, who was born and passed his early life in the immediate neighborhood of this particular place, once told me that, during his boyhood, his grandfather, Major Amos Farnsworth, used to relate how the affair happened, though it was before his grandfather's recollection, and he was born on April 28, 1754. The Major's father, Amos, Senior, had previously owned the neck or peninsula, and it was during his ownership that the new channel was formed. He continued to hold it, until the day of his death, which occurred on December 5, 1775, by the upsetting of a boat, in which he and his youngest son, Benjamin, were crossing over the river to this very island, where both were drowned.

It is highly probable that the neck was cut through, and the island formed, during a freshet which took place in January, I75I. In a note-book kept for many years by Joseph Farwell, of Groton, is the following entry:-

in Groton January the 22, $175^{0-1}$ their was a grate storm of Rain and wind to that Degree that it Blew down 4 Barns and one house and Rent a Grate Number of Barns and other Buildings to that Degree that the oldest person Now Living Cant Rember the Like.

The following extract is taken from "The Boston IVeekly News-Letter," January 31, 175 I, and undoubtedly refers to 
the same freshet, though the date there given differs from the one mentioned by Mr. Farwell. Perhaps in his note-book he wrote down the time of entry instead of the date of occurrence.

Since our last we have receiv'd further Accounts of the Damges sustain'd in the last Storm,

Particularly from Westerly in Rhode Island Colony, we here a House was blown down, and one Man kill'd ; and from Lancaster, that a Barn there was blown down, and a Horse and six Sheep kill'd.

Also from Groton in the County of Middlesex, that on [Wednesday] the I $^{\text {th }}$ Instant, there was a very great Flood, such as has not been known for several Years past, and that many Hundred Pounds Damage has been done thereby to the Bridges, \&c. it took the Bridge which stood a cross Lancaster-River, so called, intirely off; which is the fourth Bridge the Town of Groton has built in about 28 years last past.

\section{DESTRUCTIVE TORNADO.}

THE following description of a destructive tornado in Warwick, Massachusetts, on September 9, I $82 \mathrm{I}$, was written by the postmaster of that town. It is given in a letter addressed to the late Caleb Butler, Esq., under these circumstances.

An account book had been picked up by the wayside near Sandy Pond, in the south part of Groton. It was found by the late Eliab G. Bolton, who judged, from the pieces of shingles and other rubbish scattered about, that there had been a severe gale in the neighborhood, and the fragments brought here by the wind. The book was fourteen inches in length, five and a half in width, and nearly half an inch in thickness. It had a pasteboard cover, on which was written, in a large and clear handwriting, "Blotter, I 802." The book was given to Mr. Butler, who, on hearing of the tornado at Warwick, wrote to the postmaster of that town about it, and received in reply the following letter. By a coincidence the postmaster happened to be the very man who had made and lettered the Blotter nearly twenty years before. The shortest distance between Warwick and Groton is forty-five miles, and the fragments, carried at a great height, must have gone much 
farther even than this. The exact time of their falling is not known, as it occurred after dark.

Caleb Butler Esq.

WARWICK October $1821-$

SiR - Yours of the $24^{\text {th }}$ Ult. was received in due course of mail - stating that clapboards shingles books \&c. had been found in the fields in Groton, which were supposed to be carried from Warwick by the wind in the late Tornado. There is no doubt of the fact, as there has been found in Winchendon and Fitchburg large quantities of the ruins of buildings that went from this place.

The daybook mentioned in your letter was the property of Ebenezer Willson, who at the time of the dates, kept a tavern in this place. - He commenced business on the It day of April iSozabout which time it is probable, the accounts in the book begin according to the description you give of the book, it was made $\mathbb{E}$ letter'd on the cover, by my own hand. A leaf of Willson's Ledger was picked up in Winchendon containing an account against myself \& James Ball in the year 1802 , which is probably posted from the daybook in your possession - If so, you will find me charged with i cwt. hay April $5^{\text {th }}-50-\left[\right.$ cents] May $6^{\text {th }}-74^{\text {th }}$ hay, $34 \&$ August I $^{\text {th }}$ 2 Pts brandy, $5^{8}$. -

I am well acquainted with all the names you mention, and the charges against them will give you a very good idea of the character $\&$ habits of some of them. Said Willson removed from this place to Upper Canada, and left his accounts \& papers with his father (Jonathan Willson) in this town, whose Dwelling-house, Barn \& out Buildings were all demolished, and the greatest part of their contents carried away by the late Tornado. Those buildings in the centre of the track of the Whirlwind, were more exposed to its ravages, than any others in its whole extent. I visited this place about an hour after the wind had passed, but have it not in my power to picture to your view, this field of desolation - everything was swept close to the ground, and that considerably torn up. The orchard was carried all awayscarcely a tree within sight, and the heavy stone walls were level with the earth. From the best information I can obtain, those buildings we [re] demolished in less than ro seconds of time. The family, six in number, who were all in the house, were providentially saved from instant death. Two boys escaped without injury, the other four were taken up much bruised and wounded - one was found in the cellar, one was taken up in the wind, and after being knocked about by the 
flying timbers, fell a little distance from where the house stood - the other two were found in different directions, among the small quantity of ruins that remained on the ground. Their confinement is a very great addition to their other sufferings. Many others have suffered severely, and some have lost, perhaps, a greater amount of property, but no others have suffered the loss of every thing that is necessary for upholding life, and at the same time deprived of their own exertions to save the scatter'd remmants, or provide a shelter for the approaching inclement season. When we look for the Buildings \& conveniences of fifty years industry and prudence, and find nothing, and when we enquire for the subjects of this calamity and are conducted to their beds where they are confined to pain $\&$ anxious solicitude, the stoutest heart withdraws in tears, to wash away an accumulated load of sympathetic sorrows.

The people in this place are doing what they can, to repair the loss of all the sufferers. The town has appropriated $\$ 700$, for their immediate necessities; but the loss is so extensive, that it seems impossible for the people here, to grant the relief which their situations require, and repair the damages which the sufferers have sustained. We count five Dwelling houses and thirteen Barns, together with a great number of other buildings, which were demolished, and their contents broken to pieces and scattered over a vast extent of territory : to this calamity we may add, a very great amount of Property destroyed, in wood, timber, orchards, fences and domestic animals. If any of the calamities to which the human family are subject, ever demanded the charity of the Public, I think this is one of the number; and I am requested by the Central Committee in this town, viz. Justus Russell Esq. Joshua Atwood \& Josiah Procter, thro this medium, to solicit of the inhabitants of the town of Groton such assistance as they may feel disposed to grant to the sufferers in this place. You, sir, will have the goodness to communicate to the Selectmen, or other proper persons, the desire of the aforesaid Committee. Your compliance will confer a signal favour upon your friend \& Very Humble Servant,

The letter is addressed on the outside to

$\mathrm{W}_{\mathrm{M}} \mathrm{Cu}$

Caleb Butlek Esqr

Groton Ms.

and franked in the right-hand upper corner thus:-

Free - WM. Cope P. M.

Warwick Ms 
The tornado happened on a Sunday afternoon, between five and six o'clock; and the dark, heavy cloud betokening the event was noticed by several persons at Groton. I was told by the late Dr. Amos B. Bancroft, that Mr. Butler himself saw the cloud from Walter Dickson's house on Farmers' Row, where he and others were engaged at the time in practising singing for the Sunday evening exercises. The Blotter and Mr. Cobb's letter have been given to the Groton Historical Society. An account of this tornado is found in Blake's History of Warwick, which says that "a part of a leaf [?] of an account-book was found in Groton, about sixty miles from the house where it was deposited in a chamber" (p. 107). The distance as given by $\mathrm{Mr}$. Blake is somewhat exaggerated.

"The Massachusetts Spy" (Worcester), September I2, gives the following description of the gale:-

On Sunday afternoon last [September 9], about 6 o'clock, a most destructive tornado was experienced in Northfield, Warwick and Orange, in the County of Franklin. It commenced near the middle of the town of Northfield, passing with desolating fury, in a direction nearly east, until it was arrested by "Tully's Mountain." about two miles north of Athol Meeting-House. It first struck and demolished a house and barn in Northfield - and thence passed to the easterly part of that town, and destroyed the house of Chapin Holton, seriously injuring him. From Northfield it passed into Warwick, completely demolishing, in its course, the house of a Mr. Brown, a daughter of whom, about fourteen years of age, perished in its ruins - and the barn and out-buildings of a Mr. Ball. A little distance east of Mr. Ball's, in Orange, a house, two barns, and a blacksmith's shop, all belonging to Mr. Smith, fell prostrate before the blast. The family, consisting of eleven individuals, escaped death by retreating to the cellar - all, save one, a young woman by the name of Stearns, who was crushed to death by the falling timber. Several others were, however, so seriously injured that their lives are despaired of.

We have not room nor time, at the late hour at which we write, to detail the numerous circumstances which, we learn, attended this desolating whirlwind. The width of its ravages was from 40 to 60 rods -its length about ten miles. So resistless was its force that the stoutest trees were up-rooted, stone fences removed, immense rocks torn 
from their beds, and even the surface of the earth itself broken up, as if with "the plough-share of destruction."

"The Massachusetts Spy," September 26, contains an account, taken from the Concord (N. H.) Patriot, of another violent hurricane that swept through the towns of Croydon, Wendell, New London, Sutton, and IVarner, New Hampshire, at nearly the same hour this tornado burst forth in Franklin County. They iie about fifty miles away, in a northerly direction from Warwick.

During the preceding century a severe hurricane occurred in the West Parish of Groton, now known as Pepperell, of which an account appears in "The Boston Weekly Post-Boy," August I 5, I 748. It is as follows:-

Groton, West-Parish, July 30. $17+8$.

We had here, last Thursday, the 28 th Instant, a terrible Hurricane, with shocking Thunder. The Course of the IVhirlwind was from South to North, tho' often varying, sometimes bearing to the East and sometimes to the IVest. It has torn up a vast Number of large Trees by the Roots, twisted others off in the midst, took up and carry'd away some Apple Trees to such a Distance that they could not readily be found, remov'd some large Logs from the Ground, and carry'd them to some Distance from the Place where they lay; entirely demolishing two or three Buildings, taking off part of the Roofs of some, moving others a Foot or two from the Foundation: It hath carried away a considerable part of the Roof of the Meeting-House, threw down the Fences, Stone-Walls, laid the Corn even with the Ground; the Air was fill'd with Leaves, Hay, Dust, Pieces of 'Timber, and Boughs of Trees of considerable bigness, for a Quarter of an Hour, which was the 'Time it was in passing thro' the Parish; one House which it took in its Way was garrison'd; one Side of the Garrison was thrown with great Violence against the House, the other Sides levell'd with the Ground, and part of the House carry'd away: There was a Woman and three small Children in the House, who were all wonderfully preserved, from receiving the least Hurt. Notwithstanding the great Desolation made among us, there was not Life lost, thro' the divine Goodness, tho' many Persons were in imminent Danger. We have not yet heard where it began; it went quite thro' the Parish; it's Impetuosity ceased near the Line between Hampshire and this 
Province, which is not far from us. Damage sustain'd by one Man is very considerable, what in the Destruction of his Buildings, Corn, Hay, Fences, sc. he has lost above 500 .

This description was written, undoubtedly, by the Reverend Joseph Emerson, the minister of the West Parish at that time, as it is substantially the same as the one given in the parish records, according to Mr. Butler's History (pp. 347, 34S).

\section{THE SOAPSTONE QUARRY.}

This quarry was discovered, in the year 1828 , by John Fitch on his farm in Groton, situated a mile north of the village. He worked it in a small way for several subsequent years, sawing the stone by hand at a shop by the roadside, near his house; but afterward he built a steam mill at the quarry, forty or fifty rods away. In the year 1855 the establishment was bought of the Fitch heirs by the Honorable Samuel Adams, of Townsend, and Daniel McCaine, and during I 857 the quarry was worked by Mr. Adams.

In May, I858, Mr. McCaine, with his twin brother, David, and another brother, William, removed from Francestown, New Hampshire, to Groton, and took charge of the business, Mr. Adams having died on April 5 of that year. They enlarged the shop, improved the machinery, and worked the quarry on a grand scale. In the spring of I 859 the building was burned down, and on the same site another and larger one was put up.

In I 86 I the Adams heirs sold out their interest to the McCaine brothers, who continued the business till September, I 864 , when the mill was again burned. The next month the property was soid to a stock company, known as the Groton Soapstone Company, which represented a capital of $\$$ I 00,000 . Just before the formation of this company, a "Statement" regarding the location and value of the property was printed, accompanied by reports from the Superintendent, Daniel McCaine, and the State Assayer, Dr. Charles Tracy Jackson, 
on the resources of the quarry. Their estimates were liberal, and showed, on paper, that large profits would result from investments in the company.

In the summer of $1 S \sigma_{j}$ the new company completed their mill, which was 80 by 50 feet in dimensions, with enginehouse attached. It was run by a Corliss engine of 75 horsepower, and contained six gangs of saws. It had the latest improvements in machinery, and was considered the bestequipped and largest-factory of its kind in the country.

During the year I $\$ 67$ the McCaine brothers, who were still in charge of the quarry, invented and patented a process for making artificial stone. The patent was subsequently sold to the Groton Soapstone Company, which soon afterward became the Union Stone Company. For a while the new process was considerably used in connection with the soapstone, and finally became the exclusive business of the company. The affairs of the corporation, however, did not seem to prosper, and, dividends not forthcoming, the establishment was abandoned and dismantled. The capital stock was then increased, and another mill built at Revere, near Boston, where artificial stone was made under the patent.

The following account is taken from "The Groton Herald," Nay 29, I $830:-$

Groton Soap-Stone Quarry. - An extensive quarry of Soap-stone was discovered in this town, about two years since. It is on the land of Mr. J. Fitch, who was led to the discovery by accident, and commenced penetrating into it immediately, with considerable success. Ve have seen some specimens of the stone, that has been wrought into hearths, which retains a beautiful polish - and we understand that while the workmen penetrate deeper into the rocky caverns, the stone becomes more pure and y aluable, and promises an inexhaustible supply. The quarry is opened on the side of a hill, in two or three places, and the descent from the top is about forty feet, over projecting crags and huge blocks of stone, above which stands a forest of tall trees - the whole forming a grand and pleasing scene. The trees are seldom felled, and as farther researches are made into the earth, they often fall to the bottom of the cavity and are drawn out in the manner that stone is taken from the opening of the quarry. New discoveries 
are made almost daily, and we should judge from the appearance of what has already been done, that it is but a slight introduction to a vast territory of stone, of a very valuable kind.

Some minerals have also been found in this place. Particles of iron ore may be seen among the stones, and black lead has been picked up in considerable quantities - and minerals of different colors, sparkling among the rocks and waters, can be distinctly discerned. Several springs gush from between the crags, and the water has filled the bottom of the quarry so as to delay the work, in one or two places; but this obstruction is shortly to be remedied by fixing pumps to take away the water, and greater progress will doubtless be made the ensuing Summer, than formerly.

The situation of this quarry is remarkable for its beautiful and romantic scenery - the wildness of nature which presents itself in varying scenes, and the rich groves and forests that appear on every side. After leaving the road we are led about a half mile, over valleys and variegated hills, till the path begins to be lined by huge pieces of Stone that have been drawn from their bed in immense quantities. and thrown aside like the worthless corering of a more valuable substance. The quarry is hidden from the riew by towering trees that overshadow it, until winding along the rocky path, we stand before a damp and craggy place that opens at once upon us; here are heard the sounds of workmen, who are employed in purging from the bowels of the earth this stony substance - some of which is so soft as to yield to the pressure of the fingers, while other kinds are of a much harder nature. The whole is remarkably smooth and soap-like, and Mr. Fitch owes his discovery to the fact that a part of a stone adhered to his axe, as he struck it inadvertently, while cutting wood on his farm. Many fragments were scattered over the surface of the ground at the time, but they had never excited attention until this late period.

An attempt was made, more than fifty years ago, to dig down on Mr. Needham's land eighty or ninety rods to the southward of the quarry, in order to strike the vein of soapstone. Many days of fruitless labor were thus spent, but the dip of the stone was too deep to be reached.

Mr. Fitch's first shop by the roadside was originally attached to Major William Swan's house, - which is now occupied by Charles WVolley, Jr., on the north side of the Common near the burying-ground, - and at the end of the eighteenth century was used as a store. 


\section{WOODS OF GROTON.}

I HAVE seen a printed slip, containing on one side a list of the "Woods of Groton," and on the other some suggestions in regard to "Reading." The list comprises Ios names of different trees and woody shrubs, and was made by James $T$. Bennett, at that time a member of the High School, who had collected specimens of each kind mentioned. It was the result of a recommendation to the scholars, and is referred to in the "Annual Report of the School Committee of the Town of Groton, for the year ending March, I 885 " (p. 8).

\section{GIBBET HILL.}

A QUERY relative to this Hill appeared on page 388 of "Notes and Queries" (London), May I6, I 896; and several answers to the same were printed on page 432 in the issue of Nay 30.

Gibbet Hill is the name of an eminence overlooking the village of Groton. Massachusetts, which has been so called from the earliest history of the town. The tradition is that once an Indian was gibbeted on its summit; but this is known now to be false. I have a notion that the name was brought from home by the original settlers, and given to the hill, perhaps from its resemblance to some other hill in the old country. I wish to ask if this is a name ever or often applied to hills in England.

S. A G.

Gibbet Hill ( $8^{\text {th }}$ S. ix. 388 ). - There is a well-known Gibbet Hill on the road from Coventry to Kenilworth. $\mathrm{H}$. K.

In Halifax a number of the principal thoroughfares are called lanes, - e.g., King Cross Lane, Hanson Lane, Pellon Lane, Gibbet Lane. All these rise gradually from the centre of the town. The latter is occasionally referred to by old inhabitants as Gibbet Hill. At the foot of it, in a cul-de-sac, the dungeon still exists, I believe, if not the gibbet. Gibbet law, or hanging, was at one time in vogue in Halifax, and administered against persons faund guilty of steal- 
ing pieces (i.e., rolls) of cloth. The old.Piece Hill, or cloth merchants' market, is still extant, but has been spoiled by an admin. istration regardless of old associations.

J. H. W.

[See 'Halifax Law,' $8^{\text {th }}$ S. viii. 368, 410; ix. 92, 353.]

Gibbet Hill seems a common name for hills, at any rate in some parts of England. I can recall two so named within a comparatively short distance from one another-viz., Gibbet Hill, a short distance outside Coventry, on the Kenilworth road, and Gibbet Hill, near Lutterworth, on which hill the road from that place to Rugby crosses that old Roman road called the Watling Street. In both of these cases it is traditionally said that gallows were formerly erected by the roadside at the summits of the hills.

G. H. P.

Although the following brief extract from that interesting book, "Historical Essays from Paris, translated from the French of M. de Saintfoix," I 767, Vol. i. p. I 2 I, does not afford a direct answer to the query of S. A. G., yet it is suggestive, and tends to throw some light on the subject: -

"Gibet. A corrupt word from Gebel, which signifies in Arabic a mountain. In former times, criminals were executed in France upon high grounds, that the punishment inflicted might be seen at a great distance."

IV. I. R. T.

\section{SOME ROADS AND STREETS.}

THE roads in Groton were laid out at first to meet the needs of individual families. The use of them was confined to the inhabitants, as there was no other public to accommodate. The various house-lots had been selected by their owners with reference to convenience for tillage, or some other local advantage; and these were to be comnected by highways. The roads originally were of great width, often being four or six rods wide, and the bends and turns in them, for the most part, were owing to good reasons. At the present time even, in some places, the highway still shows the original width of six rods. Perhaps a tree or some other obstruction would 
make a crook in the road; and in the course of time the cause might disappear, but the effect would remain. In consequence of their width, encroachments have often been made by the abutters; and on various occasions the town has appointed committees to prevent such trespasses, and to prosecute the offenders. The committees, however, generally settled with them by receiving payment for the land.

The following streets were accepted by the town, on the dates given respectively after each one:-

$$
\begin{aligned}
& \text { Station Avenue . . . . January 15, I849. } \\
& \text { Willowdale Street . . November 12, I849. } \\
& \text { Court Street . . . . . . April 2, } 1855 \text {. } \\
& \text { Champney Street . . . November 6; I } 888 .
\end{aligned}
$$

The easterly end of Pleasant Street, from the junction of Elm Street, was laid out by the County Commissioners on August 2O, I 834 , and at the same time that part of the Lowell Road which runs on the north side of the First Parish Meetinghouse. High Street, now known as Powder House Road, has never been accepted by the town. The road from the Papermill Village to 'Tuity Row was accepted on March 4, I 845 .

There is in the library of the Massachusetts Historical Society a map entitled "The Seat of War, in New England, by an American Volunteer, with the Marches of the Several Corps sent by the Colonies towards Boston, with the Attack on Bunker's Hill." It was made soon after the Battle, and includes the eastern half of Massachusetts, nearly all of Rhode Island, the southern part of New Hampshire, and the eastern border of Connecticut. It gives the various townships as well as the main thoroughfares converging at Boston, and in a rude way it shows troops from various colonies on their march to that neighborhood. The "Road from Stephens Fort and Crown P!" which passes through the village of Groton, is represented on the map. Stephen's Fort was situated in Charlestown on the Connecticut River. "Rangers from New Hampshire" are shown along this route, and an "Incampment" is represented at Worcester, with "New York Grenadiers," "Virginian Horse," etc., in the neighborhood marching 
toward Cambridge. Groton Gore in New Hampshire is also represented, and appears under the name of Groton.

On April 7, 1873, the town voted that the Selectmen be instructed to establish Street Lamps in the village. Between that date and November, I 889, the number was gradually increased until there were sixty-eight such lamps. At the same meeting it was also voted to build a lock-up for prisoners. As early as the spring of I86I, a similar lock-up was ordered to be built at South Groton (now Ayer).

\section{OXEN.}

I AM told on good authority that to-day there are only three pair of oxen in Groton, while in my boyhood they were counted by hundreds. Every considerable farmer then had in his barn two or three yoke of oxen and one or two pair of steers. After a big snow-storm in winter it was the custom often to join together two ox-sleds, side by side, and hitch up a team of thirty or forty yoke, four oxen abreast. Then the farmers would drive through the deep drifts and break out the roads in the district. Sometimes they would come into the village with the long team and many drivers. It used to be great sport for the boys to get a ride on the sleds, which were always crowded with men and youngsters. This work did not cost the town any money, but was prompted solely by a neighborly interest in the welfare of others.

From time to time a "beef crittur" would be fattened and killed for meat, and thus help to eke out the expenses of the farm. A pair of steers would soon be ready to take the place of a yoke of oxen.

According to returns made by the Assessors of the town to the Commonwealth in the year, I 845 , there were I 445 "neat cattle" in the town, but of this number many were cows. 


\section{BOSTON GRAMMAR SCHOOLS.}

The Bigelow School and the Lawrence School were both named after natives of Groton. They are schools for boys and situated in South Boston. The first one was so called after John P. Bigelow, mayor of the city, and the other after Amos Lawrence, a well-known citizen.

\section{OLD MILL-SITES IN GROTON.}

THE distinct traces of an old dam on James's Brook at Groton are to be seen on the easterly side of the road to Ayer, near the extreme limits of the town. They are found on the farm, known formerly as the Benjamin Moors place, but latterly owned by Nathan F. Culver. The excavations of earth, below the dam, for the purpose of filling-in the stones, are clearly visible; and even the size of the mill-pond can be made out. None of the aged people, whose recollection goes back to the early part of the present century, could tell anything in regard to the mill that stood on this site. It is not mentioned by Dr. Oliver Prescott, Jr., in his survey of the town made in the year I794, which carefully notes all the mills at that time. James's Brook was once a much larger stream than it is now, and in particular places furnished considerable water-power.

This farm was bought of John Farnsworth, by Abraham Moors, the grandfather of Benjamin; and the deed, dated February 5, I7 I6-I7, is duly recorded in the Middlesex Registry of Deeds (Book XXIII. p. 47) at East Cambridge. From this record the following description of land is taken, which furnishes a clew to the desired information :-

Several parcels of upland \& Swampy Low land all Situate lying \& being within the Bounds and Limits of the Township of Groton in the county and province afores'd containing in all by Estimation 
One hundred \& Sixty acres more or less Improv ${ }^{d}$ Thirty acres more or less of mill pond Swamp \& upland with a three quarter part of an old Saze mill thereupon [the Italics are mine] now standing and it is Bound Northwardly upon a high way that leadeth to a farm that is called by the Name of Coycus ffarm Eastwardly with the Lands of Josiah Farnsworth Southerly upon Davis's Land \& Westerly upon Saw mill Lands \&c.

Here we have a distinct reference to this very mill, which identifies it beyond doubt; and it is interesting to note that even then, nearly two hundred years ago, it was called "an Old Saw mill." "Coycus ffarm" is the abbreviated spelling of Nonacoicus farm, which had previously belonged to Major Simon Willard. The highway, mentioned in the description, is the present road from Groton to Ayer. A record of John Farnsworth's lands in the Middlesex Registry of Deeds (XIII. 336), on May 10, 1700 , refers to his "Saw Mill Land," which was without question this parcel, showing that he owned it at that time.

Going back to a still earlier date, in a description of Farnsworth's lands, on December 9, I680, as found in "The Early Records of Groton" (p. I 82 ), reference is made to "a pece of swamp land, lyeing betwixt the pond at John Page's saw-mill and the bridg that goe to Nonicoycus, bounded round by the town's coñon land." Undoubtedly Page's saw-mill, here mentioned, was the same as Farnsworth's, as the sites of the two appear to be identical; and "the bridg that goe to Nonicoycus" is still standing over James's Brook, very near the bed of the old mill-pond. Page's mill was built probably soon after the re-settlement of the town in the year $167 \mathrm{~S}$; and this dam furnishes, perhaps, the earliest trace of man's work that can be identified within the limits of Groton or its neighborhood.

Many years ago John Chamberlain had a saw-mill on Martin's Pond Brook, near the foot of Brown Loaf on its northerly side. He was known about here as "Paugus John," from the fact of his killing the Indian chief Paugus, in Lovewell's Fight at Pequawket, on May S, I725. An account of this action 
is found in Chapter IV. of "Groton during the Indian Wars." Even now there is a deep place in Paugus Brook, known as Paugus Hole, on the west side of Brown Loaf, where, it is said, the body of Paugus's descendant, who came to kill Chamberlain, many years after the Fight, was sunk, after he himself was killed. A small elm stands on the south bank of the brook, very near the place. Chamberlain is supposed to have died about the year 1756 , though no record of his death is found. The appraisal of his property was made on March 31 , 1756 , according to papers in the Middlesex Probate Office at East Cambridge. The old mill-race is still to be seen; and twentyfive years ago, in company with Francis M. Boutwell, Esq., I examined the site. The mill is not mentioned by Dr. Oliver Prescott, Jr., in his survey of 1794, and, of course, was not standing at that time. It was sold by Joseph Gilson, Jr., husbandman, to Eleazer Gilson, cooper, February I3, I7 I6-17, as recorded in the Middlesex Registry of Deeds (XIX. I3 I, 132). The land is described as lying on both sides of "Brownlofe Brook," and bounded westerly by the road leading to John Chamberlain's corn-mill, which at that time was the mill mentioned in the next paragraph. There has been, however, a grist-mill on or very near the same site in modern days, which was built by George Russell about the year 1870 ; but this was carried away during a freshet in March, I 877 .

A grist-mill stood for a long period on Baddacook Pond Brook, about two miles and a half from the Unitarian MeetingHouse, on the Lowell road. It is given by Dr. Oliver Prescott, Jr., on his plan of 1794 , and was standing in the early part of the last century. John Chamberlain, yeoman, conveyed it to Eleazer Gilson, February I 3, I 7 I6-17, - the same day that Joseph Gilson, Jr., sold his mill to Gilson, as recorded above. The grantor afterward became the famous Indian fighter, as already stateci. The land is described as lying on the southerly side of "Battecook Medow," and from the description the road ran then as it does now. When Mr. Butler's map was made, from a survey during the years I 828 and I 829 , the mill belonged to Amelia Woods, and before that had been owned successively by her father and brother, Nahum 
and Nahum, Jr. It was taken down about I860, having for several years previously fallen into disuse.

Eleazer Gilson appears to have been a large owner of millproperty at an early period in the history of Groton. He bought of Isaac Parker, December 7, I726, a saw-mill situated on Mulpus Brook, as recorded in the Middlesex Registry of Deeds (XXVI. 336). In modern times he would have made his mark as an extensive manufacturer or a railroad magnate.

During my boyhood there was a mill for grinding and sawing at West Groton, - or Squannacook Village, as it was then called; but this was taken down many years ago. It was first built by John Tarbell, the father of the late Colonel Abel Tarbell, who died on October 19, I860, at the advanced age of 86 years. John died on September 9, I802, aged 79. A mill for the manufacture of leather-board now occupies the site.

There was also another mill for grinding and sawing, where the Hollingsivorth paper-mills now stand, on the Great Road north of the village. At the end of the eighteenth century it was owned by John Capell, but it disappeared a long time ago, in order to make way for the new buildings. Both these grist-mills, last mentioned, are given on Dr. Prescott's plan of 1794 .

\section{BILLERICA BRIDGE.}

AT an early period in our colonial history the travel from Groton to Boston went by a circuitous route through Chelmsford and Billerica, where there was a bridge over the Concord River, built by several towns, - of which Groton was one, - and supported jointly by them for many years. The Reverend Henry Allen Hazen, in his "History of Billerica" (p. 98), says that the town of Groton paid toward the repairs of the bridge in the year 1665 the sum of $£_{3} 14 s .7 d$. out of a total of $£ 212 s .2 d$. - probably the first assessment paid by the town, though there is no allusion to the matter in the town-records, which are not entircly complete at this period. On March 12, 1665-6, the Selectmen of Chelmsford gave 
notice to the town of Billerica that they would no longer help keep the bridge in repair, whereupon it was voted by the Selectmen of Billerica that they would take up some of the planks and thus stop all travel, which was undoubtedly done. How long the bridge remained impassable, or how long the difficulty continued, there is no record; but probably the trouble was not settled until the General Court, twenty months later, interposed its power and decided the matter. At its session beginning on October 9, I667, it is recorded:

In Answer to a motion made by the Deputjes of Billirica \& chelmsford in refferenc to the bridge ouer Billirica Riuer - It is Ordered by this Court thatt according to the Agreement of the Coninttee of the Generall Court \& Comitte of that Countje respecting bridges bearing date Aprill 17.1660 the sajd bridge shall be repayred \& vpholden by the Tounes of Billirica chelmsford \& Groaten. \& all such ffarmes as are there granted when they shall be Improoued in proportion to their Country rates. \& shall be freed from the majntenanc of all other bridges excepting only in their oune Tounes.

[General Court Records, IV. Part 2, 59i.]

In carrying out this order, which had reference only to the repairing of the bridge, the County Court at Charlestown, on December I 7,1667 , appointed a commission of four men, - - of whom Captain James Parker, of Groton, was one, - who were authorized to make a contract "with some able and honest artificer" for building it anew; and accordingly to that end they made an agreement with Job Lane, of Billerica. The written contract containing all the specifications in detail is still preserved; and it stipulated that the Groton payments, if Lane so chose, should be delivered near the bridge, while it was building, and after that in Billerica. The work was to be done before September 29, 1668 .

In the year $1676,-$ according to Mr. Hazen's History (p. 99), - the complaints about the bridge were repeated, and there was again united action of the towns in repairing it ; but probably at this time Groton was relieved of all assessments, as the town was then deserted. During the next twenty years no further complaint is recorded; but at the end of this period 
(probably in the year 1699 ) the bridge was swept away by a flood. Then another controversy arose on the old subject of proportioning the expense; and in order to settle the difficulty a request was sent out at this time by the Selectmen of Chelmsford to the towns of Groton, Dunstable, and Billerica, asking them to appoint a committee, who should be authorized to meet and act in the matter. Accordingly a meeting was held, probably at Chelmsford, when Thomas Williams and James Blanchard, the town clerk, were present, representing the town of Groton. (History of Billerica, p. IOO.) One result of this consultation was to change the location of the bridge and place it more than a mile farther up the river. The following entries in the Groton town-records probably refer to a subsequent meeting of the committee, which soon followed the first, when there was evidently a hitch in the proceedings:-

december $2 \mathrm{I}$ at a town meting legely warned the town did then uote and declare that $y^{a}$ will chuse to men for to be the towns agents for to maniadge the case a bought the brigde and for to imply a lawyer in the behalfe of the town and that $\mathrm{y}^{\mathrm{a}}$ will raise money for to bare the charge of said men

JAMES BLANChaRd tozon clark

at a town meting legely warning december: 2 I 1698 . capãn Prascott was chosen for to go to chelmsford to meett with the commety and insign farnworth was chosen for to go with him to chamesford.

JaIIES Blanchard tozen Clarke

december: 211698 at a town meting legelly warned the town did uote and chuse capt prescott and insign faruworth to go to Chelmsford to mete with the commete and to act in the towns be halfe acording to there best discrestion refering to billarca bridg

Janes Blaxchard tozon Clark

December 21: 1698 : at a town metinge legelly warn the town did chuse capt prescott and Insign farnworth to be the to men for to acte in the towns be halfe for to do the work Spock of in the other uot

James Blanchard town Cla $[r k]$

The bridge was built on the new site some time during the year I699, but for one reason or another now unexplained, the town of Groton refused to pay the amount assessed as her share of the expense, and recourse was again had to the Gen- 
eral Court. At the session beginning on May 3 I, I699, and continued by several prorogations until March I 3, I699-1700, the following enactment was passed:-

An Act relating to Biflurica Bridge, in the County of ftlidolescr.

GOR Issuing of the Controversie between the Tozens of Groton, Billerica and Chelmsford, and the Inhabitants of the Farms Adjacent, arising by reason of the refusal or neglect of the Agents for. the Town of Groton aforesaid, to pay the Sum set and proportioned on their Tozon, for and towards the Erecting and Building of the Bridge in the said Towen of Billerica, in the County of Middlesex; wothich ought in Equity to have been paid; the Sum being Twenty Four Pounds, and Ten Shillings.

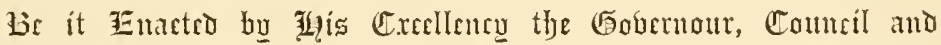
Eicpresntatiues in Grarral Court Assembled, and by the Autlority of the samte, That the Court of Quarter Sessions of the Peace, to be holden at Concord, in the said County of Middlesex, on the Second Thesday of Fune next, are hereby ordered and impowred to issue and send forth a Warrant, to the Select-men or Assessors of the said Town of Groton, Requiring them forthwith to Levy and Assess the said Sum or Tuenty Four Pounds, and Ten Shillings Money, on the Inhabitants of their Town according to Law ; and with the Assessment to deliver a Warrant to the Constable of their Town, Requiring him to Collect and Gather the same ; and the said Sum so Collected, to deliver and pay in unto Major Thomas Hinksman, Major Fonathan Tinge, and Mr. Foln Lane, Undertakers for the Building of the Bridge lately Frected in Billerica above-said; and the said Constable to pay in the said Sum, and issue and settle his Accompt with the said Undertakers, at or before the First Day of August next. And Groton shall not be liable to Contribute anything further toward the Repair or Rebuilding the said Bridge at any time for the future; unless the General Court or Assembly shall Order the same.

"Acts and Laws, of her Najesties Province of the Massachusetts-Bay in NewEngland" (Boston, 17 14), p. I29.

The town's exemption from liabilities on account of the bridge, as implied in the last clause, however, did not last long, as in the course of a few years this paragraph was repealed. At the session of the General Court beginning on May 30, I 7 I6, the following enactment was passed:- 
An Act relating to the great Bridge in Billerica.

WHEREAS the Agents for the Touns of Billerica and Chelmsford, by Direction of the said Tozens in their Petition to this Court at their present Session, have shewed forth, that there is a Great Bridge erected over Concord-River, in the Toumship of Billerica, and that the suid Bridge wess built by the Towns of Billerica, Chelmsford and Groton; and according to a former Settlement made by a Committee appointed for the Settlement of the Charge of the Bridges in the County of Middlesex. But the Town of Groton, upon Application to this Court in 1699 , did obtain a Discharge from either building or repairing for the future, without further Order from this Court. And further it was alledged in the said Petition, that the said Bridge is fallen into such Decay, that it is no Ways profitable to Repair, or safe to Improve any longer as it noze is, but that the same must of Necessity be newe-built; and that it is apprehended the Charge will be so great that the Burthen will he too heavy for Billerica and Chelmsford to bear, for the Reasons therein given, which more properly ought to come under Consideration of the Fustices of the Conrt of General Session of the Peace in the Connty of Middlesex :

Lie it therefore betared and enacted bo the bonourable the 亚 Gouernour, Council and Liepresentat:Ges, in Goneral Court assembled, and by the Authority of the same, That the Matters contained in the said Petition be referred to the Consideration of the Justices of the Court of General Sessions of the Peace for the said County of Middlesex, at their Quarter Sessions; who are hereby fully authorized and impowred to take such Order about the said Bridge from Time to Time, and at all Times hereafter, as shall be judged meet and convenient, and to settle the Charge of the same, upon any, or every the Towns of the said County. And the Paragraph in the Law exempting the Town of Groton, from the Charge of the said Bridge, is hereby repealed, and made nuil and void.

"Acts and Laws, of his Majesty's Province of the Massachusetts-Bay in NewEngland" (Boston, 1759), p. 191.

How long after this time the town was called upon to help support the bridge, I an unable to say, but probably not for many years. The line of travel from Groton gradually worked its way to Boston in a straighter direction, and left the Billerica bridge eight or ten miles to the northward. 


\section{AN OLD DEED.}

Ix presenting an old parchment deed, duly signed and sealed, to the Massachusetts Historical Society on June I 4, ISSS, I gave the following description of the paper. As it relates to the neighborhood of Groton, I include it in this series of articles.

It was given by Abigail Flint, John Flint and Mary, his wife, to Thomas Wheeler, all of Concord, and dated June I9, I674. It conveyed 800 acres of land, which is described as

lying and being in two parcells in the Wilderness Northerly from the towneship of Grawton at or neare unto a place commonly called by the Indians Aukecunsick: the one parcell being bounded on the South Easterly Side by a River that ruñs from the Towne of Grawton: and the other parcell lyeing about one hundred Rods distant from the affore mentioned parcell of land on the North Westerly Side thereof: Both which said parcells of Land being bounded out by marked trees:

It is evident from the description that both these tracts of land lay on the northwesterly side of the Nashua River, and one of them was bounded by that stream. The two parcels come now within the limits of Hollis, New Hampshire, where the name of the original owners is still perpetuated by a Flint's Pond and a Flint's Brook. The Indian word Aukecunsick seems now to have died out entirely, and I cannot find that it exists in the neighborhood, even in any modified form.

These two tracts of land had been granted at the session of the Gencral Court beginning May 22, I66I, to the widow of Thomas Flint and her second son John, in consideration of the public services of her husband and his father, who had been during eleven years a Magistrate of the Colony. Mrs. Flint had been left with a numerous family, " many whereof were in minority;" and the burden of their support had fallen on John, for which reason he was to have an equal interest in the grant with his mother. The return of the survey was 
made at the session of the General Court beginning May 27, 1663 , and duly approved by that body.

Through the signature of Abigail Flint, the deed furnishes the given name of Thomas's widow. John, the son, married Mary, the daughter of Urian Oakes, the President of Harvard College; and their signatures, also, are attached to the document. The grantee was afterward known as Captain Thomas Wheeler, the famous Indian fighter, who wrote a "Narrative" of his campaign against the savages.

\section{JAMES'S BROOK.}

Mr. BUtler, in his History (p. 244), says that James's Brook took its name from Captain James Parker, a large landowner along the banks of the stream. His ownership, however, was near the upper part of the brook, and did not extend to any great distance below. During the last seventy-five years this explanation of the name has been generally received, and before that period but little thought was given to the subject. Recently my attention has been called to a different view of the question by the late Honorable Claudius Buchanan Farnsworth, of Pawtucket, Rhode Island, who was a native of Groton. Mr. Farnsworth belonged to a family that had lived for more than two centuries in the immediate neighborhood of the brook, and he was himself very familiar with the locality and the traditions of the place. Under the date of September 3, I 888 , he writes:-

When a boy, living near the brook and crossing it very often, I used to hear people say that it was so called after an Indian, named "Jeems," who fished along its banks and finally was found dead in the vicinity. In my boyhood that was the popular talk, and I have heard it many times over. It is called "James his Broke" in the town-records, November 27, I664, when things could hardly have got so settled that common usage would have given to the brook the Christian name of a proprietor living near by. 
Mr. Farnsworth's point appears to be well taken, and particularly in the light of the fact that there was in very early times an Indian by the name of James, who had some business relations with John Tinker, one of the petitioners for Groton and an original settler of the town. Certain papers bearing on these transactions, which covered a period of several years following February I3, I 656, are printed in "Groton during the Indian Wars" (pp. I79-I8I). Like all Indians James was a famous sportsman, for he agreed to furnish within a given time a large number of beaver skins. He was friendly to the whites, and probably a noted character in his day.

In the Indian Roll, - the earliest book of town-records, there are only tivelve references to James's Brook, which all appear to relate to the lower half of the stream, - to the part below Matthias Farnsworth's house. Perhaps the name was first given to the lower part of the brook, and then by general consent worked upward to the source of the stream.

On page 57 of the printed Records, under the date of June $S$, I680, there is an allusion to "the Brook by the Captains," which evidently means this brook. If the name had been taken originally from Captain James Parker, in use as early as November, I 664, and applied to its whole length, it seems as if it would have been called James's Brook at the time of this entry in June, I680.

\section{CAMP STEVENS AT GROTON.}

DURING the IVar of the Rebellion, in the autumn of 1862 the Commonwealth of Massachusetts established a military camp at Groton, on the triangular piece of land situated in the southwesterly part of the town, and bounded by the Peterborough and Shirley Railroad, the Nashua River and the road to Shirley Village. It contained eighteen or twenty acres, more or less, and at that time belonged to Joseph Cutts ; the entrance was near the angle made by the railroad and the highway. The Fifty-third Regiment of Infantry, Massachu- 
setts Volunteer Militia, while its ranks were recruiting, was encamped on this ground. The regiment was raised from Groton, and Clinton, Leominster, Fitchburg and other towns in the neighborhood belonging to Worcester County, and was mustered into the public service for nine months.

Special Order, No. 916, issued by the Adjutant-General of the Commonwealth, September 19, I862, contains the following:-

A camp of rendezvous is established at Groton Junction, Middlesex Co., where barracks are being built, which is designated Camp Stevens. Capt. W. C. Sawyer, 23d Regt. Mass. Vols., is appointed Commandant. Due notice will be given when the barracks are ready for use.

Special Order, No. 955, under the date of September 23, has the following:-

Lindsey Tilden [Charles Linzee Tilden], zoth Regt. Mass. Vols., is detailed for Post Adjutant at Camp Stevens, Groton.

The camp was so named in memory of General Isaac Ingalls Stevens, a native of Andover and a graduate of West Point, who was killed in the battle of Chantilly, Virginia, on September I, I862, about a fortnight before the camp was established.

The Commandant was Wesley Caleb Sawyer, born in the adjoining town of Harvard, on August 26, I839, who graduated at Harvard College in the class of $185 \mathrm{I}$. Soon after leaving Cambridge he was commissioned, on October 8, I86I, as a Captain in the Tiventy-third Massachusetts Volunteers, and he left the State with that regiment. He was attached to the Burnside expedition, that went to North Carolina; in the Battle of Newbern, March 14, I862, he was severely wounded, which resulted in the amputation of his left thigh, and necessarily prevented him from further participation in an active campaign.

The regiment left Camp Stevens, on Saturday, November 29, for New York, where it remained until January 17, I863, at which time it embarked for New Orleans. Subsequently to the departure of the troops from Groton, the following order was issued:- 
Comilonivealth of Massachusetts,

Head Quarters, Boston, Dec. 20, 1862.

Special Order, No. I 3 I I .

The troops which were enlisted and mustered into service at Camp Stevens, Groton Junction, having left the Commonwealth for the seat of war, Capt. Wesley C. Sawyer, Commandant of the Camp, is relieved from further service, and I am directed by His Excellency the Commander in Chief, to thank Capt. Sawyer for the acceptable manner in which he has performed the duties of his post.

By order of the Commander in Chief,

William Schouler, Adjt. General.

Since the war Captain Sawyer has studied at Göttingen, Germany, where he received the degree of Doctor of Philosophy. He has held the professorship of Philosophy and Rhetoric at Lawrence University, Appleton, Wisconsin, but is now living at San José, California.

The barracks and other structures used by the soldiers at Camp Stevens have long since disappeared, and not a trace of the former occupation is to be seen. Years ago some of the buildings were taken down, and the rest were removed, mostly to Ayer. George James Burns, Esq., a lawyer of that town, wrote an interesting article for "The Groton Landmark," June 25 , I 887 , which traces the history of many of these buildings.

In the autumn of I \$62, Dr. Edward Jarvis, of Dorchester, was appointed by Surgeon-General Dale to visit the various camps in the State, of which there were ten, and report on their sanitary condition. The result of his labors may be found in two communications printed in "The Boston Medical and Surgical Journal" for Decenber 4 and I I, I862 (LXVII. 364-367 and 38I-384, respectively), wherein he makes some criticism on Camp Stevens.

According to the "Record of Massachusetts Volunteers, I 86I-I 865 " (I. 390-392), the following soldiers died in camp at Groton: Henry A. Waters, of Shirley, Co. D, on October 25, I 862 ; Spencer Stockwell, of Athol, Co. E, November 20; and Daniel P. Hemenway, of Barre, Co. F, December I. 


\section{TIVO THOROUGHFARES TO BOSTON:}

Is former times there were two main thoroughfares bctween Groton and Boston: one of them, starting from the Ridges, passed through Littleton, Acton, Concord, Lincoln, and Lexington, and so on to Boston; while the other, also starting from the Ridges, passed through Westford, Carlisle, Bedford, and Lexington, where it met the first road, and thence on to Boston by a common way. A large share of the travel between certain parts of New Hampshire and Vermont and Boston took one or the other of these highways, and the incidental business was an item of much importance to the traders and tavernkeepers along the road. Eighty-five years ago there was great rivalry among interested persons to obtain the travel and teaming on their respective thoroughfares, and the trade of store and tavern was jealously watched and carefully guarded. In 1823 a sign-board was set up in the crotch of the roads at the Ridges, saying that the way through Concord to Lexington was two miles further than the one through Carlisle; and soon afterward a counter-statement was made by the other side. I have been told that, when Mr. Gerrish's store was dismantled in the summer of 1885 , before its removal to another site, this old sign-board was found there; but I have never yet been able to verify the statement.

The following extract from the "Concord Gazette \& Middlesex Yeoman," February 21, I824, seems now to give a fair and impartial version of the controversy:-

We insert below the statement of the Committee appointed to measure the roads from Groton to Lexingt(n). It is a subject, we are aware, on which the respective parties concerned feel pretty deeply. If any objections should be offered, written in a becoming style, and calculated to affect the accuracy of the subjoined statement, we shall give them publicity without hesitation. 


\section{PUBLIC ROADS TO BOSTON.}

The subscribers having been appointed, at a meeting of several of the citizens of this and the neighboring towns, as a Committee to procure a measurement of the two roads from the ridges in Groton to Lexington, they now, by special desire, publish the following result of their proceedings.

The roads in question run, one through Westford, Carlisle, Bedford to Lexington; the other through Littleton, Acton, Concord, Lincoln to Lexington. The guide-board near the Groton ridges, where the roads divide, states the road through this town to be more than two miles longer than the other, and has had a tendency, it is believed, to mislead travellers by this inaccuracy. For it calls the difference nearly three times as great as it really is. The public have a right to know the truth of the matter, and will then exercise their discretion in choice of roads to travel.

To obtain authentic knowledge on the subject, the subscribers have employed a sworn surveyor, Capt. HubBard, and sworn Chainmen to measure the two roads, beginning at Loring's Inn, near Groton ridges, where the two roads divide and going by both routes to Lexington where they again unite. The following is the result of this measurement.

\section{Road through Concort.}

From the forks of the road in )

Lexington to E. Robbins'

Robbins' to Viles's

Viles's to Patch's

Patch's to Thompson's in Concort, 'Thompson's to Bigelow's, in do.

Bigelow's to Wetherbee's

Wetherbee's to Stearns's

Stearn's to White's

White's to Proctor's

Proctor's to Nye's

Nye's to Loring's [the Ridges]

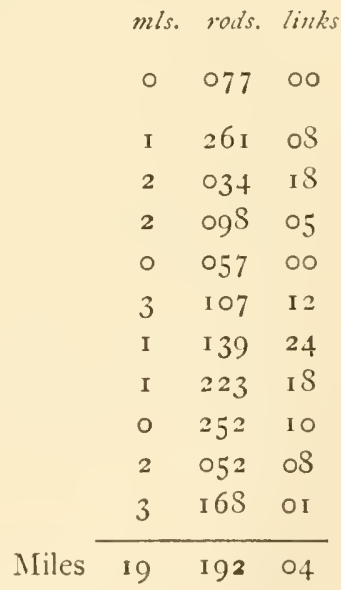




\title{
Road through Curtisle.
}

Loring's in Groton to Hartwell's

Hartwell's to Dupee's

Dupee's to Nickles'

Nickles' to Porter's

Porter's to Simond's

Simonds to the forks

\begin{tabular}{|c|c|c|c|}
\hline & $\begin{array}{c}m l s \\
4\end{array}$ & $\begin{array}{l}\text { rods. } \\
\text { oss }\end{array}$ & $\begin{array}{c}\text { linkis. } \\
2 \mathbf{I}\end{array}$ \\
\hline & 3 & I I I & 24 \\
\hline & 2 & 190 & OI \\
\hline & 4 & oSS & 04 \\
\hline & 2 & $2 S_{1}$ & 16 \\
\hline & I & 153 & IS \\
\hline Milles & IS & 275 & 09 \\
\hline & $m / s$ & rods. & links \\
\hline & 19 & 192 & 04 \\
\hline & IS & 275 & $\circ 9$ \\
\hline & & & 20 \\
\hline
\end{tabular}

From the preceding statement it will be seen that the road from Loring's tavern to Lexington through Concord is 236 rods and a fraction longer than that through Carlisle; this difference however is less than three quarters of a mile.

There are eleven public houses on the road through Concord: and six public houses on the road through Carlisle.

This measurement of the Carlisle road agrees, within a very few rods, with the measurement of that road by CALer Butler, Esq. of Groton. If this gentleman had also measured the road through Comiont the public would have had a correct statement of the distances. But unfortunately the gentleman. who about that time measured the road through this town, apparently did it with rery little accuracy. In one place, namely, from Thompson's tavern in this town to Bigelow's, the short space of fifty-seren rods, he made a mistake of sixticn rods; we therefore place little confidence in his measurement of any part of the route. It should be observed that one public house in this town, viz. Mr. ALExander's within a few rods of Mrr. Bigcluris was accidentally not mentioned in this measurement of roads.

\author{
TOSIAH D.AVIS. \\ PHINEAS HOWE. \\ EBENEZER THOMPSON. \\ STEPHEN PATCH. \\ DANIEL SHATTUCK.
}




\section{HIGHWAY FROM GROTON TO CONCORD.}

AT a session of the Middlesex County Court, held at Cambridge and beginning on April 1, I673, according to the records, the following commission was appointed:-

Mr Jn? flint, Jn: Smedly, John fiske Jun ${ }^{r}$ Abrañ Parker, James Knap \& Robert Bloud, are nonininated \& impowred by this Court, to lay out \& settle the high way between Grotton \& Concord, \& this worke to be attended the $2 \mathrm{I}$. day of May next, at 9 : of the clocke in the morneing, to meet \& begin at the westerly end of Tadmock meadows (III. $\left.5^{8}, 59\right)$.

The members of the foregoing committee lived, respectively, as follows: Flint and Smedly at Concord; Fiske and Parker at Chelmsford; and Knap and Blood at Groton. The Tadmock meadows lie now within the limits of Westford, though Tadmuck is the usual way of writing the word at the present time.

At a session of the same Court, held at Cambridge and beginning on April 4, 1682, the following action was taken:-

In answr to a motion made by the select men of Grotton the Coninttee forminly chosen out of Grotton Concord \& Chelmsford are appoynted to perfect $y^{\mathrm{e}}$ Highway from Grotton to Concord, \& $\&$ to settle $y^{\prime \prime}$ same thorow Robert Blouds farme where it may be most convenient (IV. 32).

Robert l3lood, whose farm is mentioned above, was of Concord, where he was a large land-owner, and one of the petitioners for the plantation of Groton, as also were two of his brothers, Richard and John. Richard, however, was the only one of the three who settled in Groton; and after his death, which took place on December 7, I683, administration on his estate was granted to the widow Isabel, and her three sons, James, Joseph, and Nathaniel, whose names are given, presumably, in the order of their ages.

The following extracts, taken from "The Early Records of Groton, Massachusetts," undoubtedly refer to the same highway:- 
At a meeting of the select men Janeuary 10 i672 a commite chussen to meet with concord men chelmesford men and Robert blood to lay out the way to the bay betwene this and the spring wheir it is most passable and the commite are maior willard sergent parker James knop The maior hauing not tim to atend it Richard Blood is chussen by the towne in his roume at a towne meeting march 17 72-73 (pp. 44, 45).

At a generall Town meeting febr is i680 It was then agreed vpon and voted that the old Commitee chusen shold perfect their work in laying out the hye way to Concord (p. 63).

\section{HIGHWAY TO CHELMSFORD.}

GROTON and Chelmsford were neighboring towns, and settled at the same time, but for some years their means of intercommunication were very limited. Originally, the road from Groton to Boston was by way of Chelmsford, and the bridge in Billerica over the Concord River, along the same thoroughfare, was built in part by Groton.

The Reverend Wilkes Allen, in his History of Chelmsford, has the following:-

\section{Road to Groton - $\mathrm{I}_{6} 6_{3}$.}

For many years the chief travel to Groton, was thro' this town. Hence a road was laid out by a joint committee of Groton and Chelmsford "beginning at Beaver brook-bridge, and rumning over the north side of Robin's Hill thro' Richard Hildrith's yard to the west end of Heart Pond, over the swamp to Thomas Chamberlin's meadow, and so on towards Groton on the east side of Tadmuck great meadows." The towns of Billerica, Chelmsford, Groton, Townsend, Dunstable \& Dracut. unitedly built the great bridge over Concord river at Billerica, and for many years jointly maintained it ( $\mathrm{p}, \mathrm{\tau} 8)$.

Presumably this statement is made, in the main, on the authority of the Chelmsford records; but it is evident that Dracut and Townsend could not have taken any part in building an early bridge, as they had not then been incorporated as towns. 
The following reference to the Chelmsford highway is found in the printed edition of the Groton records :-

The Country hye way being determened betwen this towne and Chel[ms]ford by a commitey chosen Respectiuly by both towns have agreed and according layd out thes country hye way from $y^{e}$ metting house place in the ould carte way to Chelmsford metting house sixe Rode in width from place to pla[ce] this being testefyed rndr the hands [of] the commitey at a towne mee[ting] the ro of July $6_{5}$ and excepted by the towne may be suficente to sattesfy aney home it may heraftr concern
witnesse
JAM FFISKE in the nam o[f] the towne
(P. I 4.)

\section{MIDDLESEX COUNTY BRIDGES.}

THE following paper is copied from the original report in the possession of the Massachusetts Historical Society, and found in a volume (p. 60) of miscellaneous manuscripts marked on the back "Letters \& Papers I632-1678." It shows the early period when the inhabitants of Groton were taxed for the support of a county bridge. All the signatures attached to the paper are autographs; and "Wipsuffridge," one of several forms of an Indian word, is now known as Marlborough.

$$
\text { May . 1 . } 1660 .
$$

Wee of the Comitie for Bridges in the Countie of Midlsex at our Second meeting (by Order of the Countie Court) vpon the 17 day of the $2^{d} \mathrm{~m}$ : 1660 : whose names are hervnder written. vpon farther Informacon; Inquisicoñ disscussion and Consideraco $\bar{n}$ haue Cleerly Conceived and Concluded; That the Town of Concord haue no iust ground of Complaint or Allowance from the Countie in respect of their Bridges; for the Reasons herafter Expressed.

I The three Bridges they soote and plead vpon are for their own proper; Specāl and perticuler Concernments for their Saw Mill; Iron works and other occasions; and not necessarie for the Countie or Countrie; and may at their pleasure be deserted. 
2 If Any Argument be; because they were made during the law for Each Countie to make and maynteyn their own Bridges (which they were not Onely repayred or some Addicoñ) then all other Towns must bring in their Charges for the like and be Allowed for it.

3 If the Argument be that their Burden is Aboue their Abilitie; then other Towns burdens Compared with theirs; Aduantages and disaduantages Considered; they'l find no Ease at all. Inst Sudbury at $25^{£}$ charges yearly for repayring one peece of higway in the Countri rode beside all others of like nature.

4 Though Concord dispended vpon some of their Bridges Since the Order for Counti Bridges yet neither those Bridges nor any of them were vndertaken By Order of the Countie as was Billerika and Mestick Bridges; Therfore not to be charged on the Countie; more then Sudbury; Watert ${ }^{\circ}$; Redding and Some others; who haue no Expectacon of personal profitts Comparable to Concord.

5 Wee are Credibly Informed that the way from Lancaster for whom and on whose Mocon it is Alledged that one of Concord Bridges was Erected at least in part; is now found neerer by three or fowre miles then to come by Concord; Allso A better way and such as needs no Bridge whensoeuer Lancaster Can pass from their own Town And Allso if the Countie or Countrie shall need A Bridge there; that it may be built for Ten Pounds Charge; neere Stones Farm in Wipsuffridge way.

yet for A Satisfactory Setlment with Concord and the rest of the Countie and for Auoyding all farther trouble to Courts and Countie wee think meete and conclude that the Twentie Pounds formerly granted to Concord be made vp Thirtie pounds (i e) Ten Pounds more in respect of their charges of that nature beyond some other Towns in the Countie; which Ten pounds shall be raysed in proporcon on Charlst. Cambr Watert? Wooburne; Redding Meadford and Maldon.

6 IVee Conceiue and Conclude that Billerica Bridge shall be So farr A Countie Bridge as to be vpholde by the Towns of Billerica; Chelmsford and Groton and all such farmes as are there Granted when they shall be Improued (in proporcon to their Countrie rates)

7 Wee Conceiue that Mestick Bridge shold be vpholden by the Countrie; or Else one half by the Town of Charlst. and the other 
half by Cambridge; Wooburne; Redding Meadford and Maldon in proporcon as Aforesayd.

8 Wee Conceiue \& Conclude that the Towns of Concord; Sudbury ; Lancaster; Billerica Chelmsford and Groton shold be free from Charges to all Bridges Extant saue their own Bridges as before Specified. as allso from such Bridge as shal be made in Wipsuffridge way aforesayd.

Lastly if this our returne be not Satisfactory wee haue Appointed Capt Norton Capt. Mason and Joseph Hills on notice giuen them; to Attend any farther Agitacon respecting this thing.

At A meeting of the Comitte Appointed by the Francis Norton generall Court (i. e) Cap ${ }^{t}$ Lusher Lieu: Clappe Deacon Parks it was Agreed and Ordered that Hugh mason the Conclusions Afore recited shall stand firme and be An Absolute and final determina $\overline{c o n}$ in Edmund Goodenow respect of Concord \& all other the Towns in the Countie of Midlsex and for the Town of Concord Thomas Brooks and John Smedly doe bind themselues and Successors in one hundred Pounds to John Stedman Treas ${ }^{\text {er }}$ of the Countie that their Inhabitants shall rest in the determinaco Aforesayd which bond they shal be Accquitted of on Certifficate to the Treas ${ }^{\text {er }}$ signified vnder the hands of their Selectmen; of their inhabitants acceptacon of the foresayd determinacon.

(witnes our hands

$$
\text { Signed }
$$

William Park Joseph Hils: Thos Brooks Jonathan Danforth Eleazer Lusher Hugh mason John Smedly James Parker.

Roger Clap

\section{THE DARK DAY OF I 780.}

THE following description of the famous Dark Day, and of its effects as seen in the neighborhood of Groton, is taken from "The Independent Chronicle. And The Universal Advertiser" (Boston), June I, I780. The article is signed "A Peripatetick," a signature used by James Winthrop, who was 
at that period both Librarian of Harvard College and Register of Probate for Middlesex County. Dr. Oliver Prescott, of Groton, was then Judge of Probate; and it is not improbable that the writer of the article was visiting in his family, when the account was written.

\section{TO THE PUBLIC.}

$\mathrm{O}^{\mathrm{N}}$ Friday, May 19, I 780 , at six o'clock in the morning, at Pepperrell, the peals of thunder were loud and frequent, attended with heavy rain. At seven o'clock the rain and thunder had ceased; but the sky continued cloudy. Between nine and ten o'clock the clouds were observed to thicken, and to receive continual reinforcements from the low lands. Before ten the darkness had sensibly increased, till it became difficult to read an almanack in a room with two windows. At eleven o'clock candles were lighted at Groton, and at half past eleven the darkness was so great in the meeting-house, where a court was then sitting, that it was difficult to distinguish countenances at the smallest distance, notwithstanding the great number of windows usual in such buildings. At twelve the darkness was greatest and a little rain fell. In the street the appearance was like the beginning of evening, as candles were seen burning in all the houses. The clouds were thinnest at the north, which excited the idea of an Aurora Borealis. At the northeast the clouds were very thick, and so low that hills could not be seen at the distance of half a mile. Southwesterly, hills might be clearly seen at the distance of twenty miles; but the intermediate space was so shaded, that it was impossible to distinguish woodland from pasture. At half past twelve the clouds, having been hitherto detached, begun to embody at such an height, that all the hills became visible, and the country round exhibited a most beautiful verdure. At one the clonds became uniformly spread, and it was not darker than is usual on a cloudy day. The same weather continued through the whole afternoon, except that the sun was seen for a few minutes at Acton, about three o'clock. At eight in the evening the darkness was so great as to render travelling impracticable. Although the moon rose nearly full about nine o'clock, yet it did not give light enough to enable a person to distinguish between the heavens and the earth.

The detached appearance of the clouds in the forenon is alone sufficient to account for the darkness: For as soon as the clouds 
had spread uniformly over the heavens, there was no remarkable deficiency of light. - If any one chuses to make an experiment for himself to illustrate the matter, let him take a few panes of glass, and place them at a small distance from each other in such a manner, that the sun may shine directly through them all ; in this case he will find that the rays of light are much more obstructed than they will be in passing through a single glass, equal in thickness to all the others. - The reason is obvious. - The reflection of light is from the surfaces of transparent bodies, and not from their interior parts.

Various suppositions have been made respecting this subject. Sonfe have supposed, that the earth was passing through the tail of a comet; to this it is a sufficient answer that stars are visible through the tails of comets, it is therefore impossible, that this cause should obscure the lustre of the sun. - A writer has appeared under the signature of Viator, in the Independent Chronicle, May $25^{\text {th }}$, who asserts that upon examining the rain water in tubs "I found a light "scum over it which rubbing between my thumb and finger, I found "to be nothing but the black" ashes of burnt leaves. - The water gave "the same strong smell, which we had observed in the air, and con"firmed my opinion, that the smell mentioned above, was occasioned "by the smoke or very small particles of burnt leaves, which had "obscured the hemisphere for several days past, and were now" "brought down by the rain. - I believe it is the first time that it ever came within the compass of a human imagination to suppose, that the haziness of the sky in warm weather was occasioned by ashes being lodged in it, which needed the assistance of rain to bring it down - Just as probable is the theory which accounted for the darkness, from this circumstance, that the sun and Jupiter were then in the quartile aspect. More plausible, but not more just, was the opinion of a gentleman of learning, who supposed that the nucleus of a comet intervened between the earth and the sun, and occasioned a solar eclipse. - There are various phœnomena which by no means correspond with this opinion. The clouds were seen continually rising to obscure the hills which is sufficient to account for the darkness; and the tides did not rise to an unusual height, as they would have done, had a compact body of such magnitude as a comet, been so near the earth, in such a situation, as to give us darkness instead of day. - It is in vain to assign the rapid motion of a comet, as a reason why the tides should not rise any higher than usual; for though it was but a short time in conjunction with the sun, yet it's motion 
being nearly rectilinear, it must have continued for several hours near the earth, and the universal law of gravity holds equally good, whether bodies are in motion or at rest.

A Peripatetrck.

It will be noticed that Mr. Winthrop refers to a previous article on the Dark Day, signed "Viator," which also appeared in the Chronicle; and in connection with this reference an extract from a letter on the same subject, written by the Reverend John Eliot, of Boston, to the Reverend Jeremy Belknap, of Dover, New Hampshire, under date of June 3, I 780 , has some interest. The letter is found in the fourth volume, sixth series, of the Collections of the Massachusetts Historical Society (pp. I9I-I94).

Our philosophers this way differ greatly. $\mathrm{M}^{\mathrm{r}}$ Lathrop ${ }^{1}$ printed an account of the appearance of things, \& signed Viator. He was at [Dr. Manasseh] Cutler's, Ipswich Hamlet [Hamilton], with Professor Sewal \& others, who agreed that smoke was the primary cause, \&c. He is attacked by a Peripatetick, J. W- p., who, thinking $\mathrm{M}^{\mathrm{r}}$ Williams${ }^{2}$ was the author, malitiously meant, to lessen his reputation. This gentleman gives without doubt the true cause. The detached appearance of the clouds in the forenoon will account for the darkness, as may be illustrated by taking panes of glass \& placing them at a small distance from each other.

Caleb Butler, Esq., in his History of Groton, refers to the same subject, and makes the following explanation of the occurrence : -

The darkness of this day and of the night following, which was proportionally great, was satisfactorily accounted for, by attentive observers of the phenomenon. There had been, a few days previous, very extensive fires between the settlements in Canada and New England. The state of the atmosphere and currents of the wind had favored the collection and preservation of the smoke over the territory involved in the darkness. The formation of the clouds, too, which prevailed at the time, probably had an agency in producing the result, by being in several layers and holding the smoke between them, and

1 Reverend John Lathrop, Minister of the Second Church, Boston.

2 Samuel Williams, Hollis Professor of Mathematics and Natural Philosophy. 
especially between them and the earth. As evidence, in part, of the correctness of this explanation of the phenomenon, the ashes of burnt leaves were precipitated from the rain water, a little of which fell during the day, when suffered to stand a few hours (pp. 260, 26r).

See "The New-England Magazine" (IV. 379-3\$3) for May, I833, published in Boston, for a description and explanation of the Dark Day.

\section{THE CIRCUS AND THE SHOW.}

IN modern times the circus and the menagerie have been united, and their exhibitions are now confined to cities and to large towns situated on the line of railroads. Formerly the young folks of Groton, and even children of a larger growth were treated periodically with these attractions, which then always came separately. In my boyhood, nearly every year a circus would put in an appearance in the village, and pitch a tent - a small one in comparison with those now in use for such purposes - behind one of the taverns, or on the Common just north of the Burying Ground. People would come even from the neighboring towns in considerable numbers, in order to see the remarkable feats which had been duly advertised. Large posters, put up in the bar-rooms, blacksmith shops, stables, and other public places, set forth the strange sights to be seen. The man of gigantic strength, who could pull against four horses, as well as the one with iron jaws, who could lift a small cannon by means of straps between his teeth, while some one else fired it off, the rider and the acrobat were all there, including the clown with his stale jokes. It was a gala day, and booths and benches were in order for the sale of gingerbread and poor lemonade. Drunkenness was not uncommon, and on the whole a deep impression was made on the youthful mind. Two performances were given, one in the afternoon and the other in the evening; and before the audience left their seats the place of the next exhibition was announced by the ringmaster.

These circuses used to come to Groton from Lowell, Nashua 
or Fitchburg, or some other town twelve or fifteen miles away, and they entered quietly very early in the morning, and departed soon after the evening performance. It was always a source of wonder when the actors got their sleep. Large wagons for the transportation of heavy articles, as well as lighter vehicles for the personnel, made up the train; and there was the usual sprinkling of mottled horses and trick ponies, and of course the inevitable band. The circus came more frequently than the menagerie, or "show" as it was generally called, though sometimes it was spoken of as the "caravan."

The menagerie was the more popular place of amusement, as some people would take their families there who would not allow them to attend the circus. It furnished a kind of object-lesson which taught natural history, and for that reason was sometimes patronized by persons of strict notions. The elephant was always a wonder and a delight to the boys who believed strictly the current report that he never would cross a bridge, but would swim the river, because he would not trust himself on the artificial structure. To the youthful mind the monkeys, however, were the particular attraction, and they were looked upon as almost human. If the Darwinian theory had been then in vogue, the youngsters would have become ready converts to its doctrines.

In these days of large combinations it is not at all likely that the show business will ever again be attempted in Groton; and hereafter it will be a recollection or a tradition, and not a reality. The circus and the show first came to Groton, probably near the beginning of the nineteenth century, though at that time they were managed on a very small scale. Persons whose recollection went back to the year 1810 , have told me that these public amusements were no novelty in their childhood, and of course they precede that date. The last exhibition of this character, within the limits of the town, was given at the "Junction," by the Great Oriental Circus and Egyptian Caravan, on June 4, I870. It was duly advertised in "The Weekly Public Spirit" (Groton Junction), May 26, I870, and was considered, by comparison with similar exhibitions, a very slim affair. 


\section{AN ODD MISTAKE.}

THE following announcement of a marriage is made in the "Columbian Centinel and Massachusetts Federalist" (Boston) March 22, ISOO:-

At Groton, Mr. Joel Ames to Miss Lucinda Howboath, of that place.

Knowing that Howboath was not a Groton name, and thinking that there was a blunder somewhere, I was prompted to examine the Church records, where the following entry is found which fully explains the matter:-

March 2, 1800. Joel Ames of Medford to Lucinda Howe of Groton.

Without doubt Mr. Ames belonged to a Groton family, and a notice of his marriage, sent to a newspaper at the time, probably read "boath of Groton," following an old spelling of "both"; and the printer did the rest.

\section{PROMINENT RESIDENTS.}

Among the lawyers, who have lived and practised in the town, are two Governors of the Commonwealth, one United States Senator, four other members of Congress, besides a Delegate to the Continental Congress, two members of the President's Cabinet, various Justices and Chief Justices of different Courts, four Speakers of the Massachusetts House of Representatives, an Attorney-General of the Commonwealth, a President of the State Senate, and three members of the Executive Council.

\section{MRS. SARAH C. ROCKWOOD.}

W'Hile travelling homeward, through the State of New York from a trip to the Southwest, I left the cars at Syracuse, on Thanksgiving Day (November 28, I889) with the intention 
to call on Mrs. Rockwood; but on reaching Cortland I found that she had died on November 26. I was thus enabled to attend her funeral on the next day, and to follow her remains to the grave. It was a source of sad satisfaction to pay this last token of respect to the memory of one who had known my mother from her earliest infancy.

Two years previously, at a meeting of the Massachusetts Historical Society, held on June 9, I887, I spoke as follows, in regard to Mrs. Rockwood:-

In the early part of last month I had the pleasure of meeting a kinswoman of Colonel William Prescott, who is probably the only person now living who ever saw the hero of Bunker Hill, and certainly the only one who ever knew him or ever talked with him; and her recollections are interesting. I refer to Mrs. Sarah (Chaplin) Rockwood, a resident of Cortland, Cortland County, New York, who was the youngest daughter of the Rev. Daniel Chaplin, D.D., of Groton, the last minister of the town during the period when it formed but a single parish. Her mother was Susanna, eldest daughter of Judge James Prescott, Colonel William's elder brother. Mrs. Rockwood was born at Groton on November 8, 1785, and Colonel Prescott, her great-uncle, died on October $\mathrm{I}_{3}$, I 795, - so that she was ten years old at the time of his death. The date of her birth was duly entered in the town-records, and the entry corresponds with that in her family Bible. According to the church records she was baptized on November $13, \mathrm{I} 785$.

She describes him as a tall, well-proportioned man, with blue eyes and a large head. He usually wore a skull-cap; and he parted his hair in the middle, wearing it long behind, braided loosely and tied in a club with a black ribbon, as was common in those days. He had a pleasant countenance, and was remarkably social and full of fun and anecdote. He was dignified in his manners, and had the bearing of a soldier.

I am satisfied that her recollections of that early period are clear and distinct. She shows in many ways that her memory of events long since past is still good, as it is of more recent ones. Although she has entered upon the second year of her second century, she reads the newspapers, and takes more than an ordinary interest in public affaim 


\section{COMMODORE BAINBRIDGE AND THE LAKIN FARM.}

Many years ago Commodore William Bainbridge, one of the heroes of the American navy during the last war with England, owned an undivided third of a farm of 220 acres in Groton, which was used for sheep raising. It has since been known as the David Lakin place, and is situated on the road leading from the beginning of Farmers' Row to the Great Road, just below the railroad bridge, half a mile north of the Baptist Meeting-House. It extended from the Jenkins road on its southerly border to the Great Road on its northerly; and on this farm Mr. Lakin took care of the paupers before the town had an alms-house. The Jenkins road was so called from a man who lived in that neighborhood, before the Revolution; but, by a recent vote of the town on April 6, is $\$ 85$, it has been closed to the public travel on account of its nearness to the Nashua River, and the consequent danger arising therefrom.

According to the record in the Middlesex Registry of Deeds (Book CCXXIII. p. I I5) at East Cambridge, Commodore Bainbridge sold his interest in the place, on July 2,1817 , to John Lakin. During four years before this time, in connection with Robert C. Ludlow, of Charlestown, and Charles W. Green, of Boston, Bainbridge had owned several parcels of land in the vicinity, which, presumably, were used for sheep-raising purposes, and perhaps made up this farm. John Lakin died on August 6, I 817 , at the age of 34 years; and the place was then carried on by a brother, David Lakin, Jr., who subsequently married John's widow.

This family of Lakins was descended from William, an original settler of the town, who died here on December Io, 1672 , aged 91 years. I have seen a deed, formerly in the possession of Charles Gerrish, dated 1696 and signed by John Lakin, a grandson of William, giving to his son Benjamin, land lying "nigh the River at Nod." This deed, which is duly recorded at East Cambridge, mentions "Nommucks," 
and also speaks of the "Lower sledge" and "Smith's sledge," different parcels of land in the same neighborhood. These patches, and perhaps others, probably comprised what was known then as "the sledges." Nod and Naumox are names of places used at a very early period in the annals of the town. See Vol. I., No. XV. (pp. 8, I7, I \&) of the Groton Historical Series, for a reference to these localities.

Theodore Bainbridge, of Philadelphia, was attending school at Groton Academy in the year ISI 5 ; and I am told that he was a nephew of the Commodore.

Mrs. William Gragg Blood (formerly Mrs. John Lawrence), of East Pepperell, a daughter of John Lakin, since told me that she remembered distinctly the time when Commodore Bainbridge owned an interest in the farm, which he would visit occasionally, and give general directions in regard to its management. At certain seasons there were, according to her recollection, as many as 2000 sheep and lambs on the place, which were raised more for the fleece than the mutton. At that period every farmer's wife had a loom, and homespun fabric was used in every household; but, independently of this, large mills were then projected, and manufactures were slowly creeping into New England, at Waltham and elsewhere, thus creating a demand for wool. It was thought that merino sheep-raising was to be a great industry, which the actual result did not bear out.

In former times many wild pigeons were caught in this neighborhood, during the harvest season, by means of nets; and in other country towns generally, until the whistle of the locomotive, and the growing settlements, drove away these birds from their old haunts. To such an extent was the business carried on in Massachusetts that as late as March I3, I 849, the General Court passed "An Act for the protection of Pigeon Beds," as the places were called to which the birds were tolled. During my boyhood there were on this farm a pigeon stand or roost, and a pigeon bed, near the Tuity Road, where David Lakin, Jr., in the season used to catch large numbers and sell them in the village. 


\section{A NAVAL HERO.}

THE following extract is taken from "The History of our Navy from its Origin to the Present Day i 775-i 898 " (New York, 1899), by John R. Spears. An account is there given of the last battle fought by the United States frigate "Essex" against two British vessels in the harbor of Valparaiso, on March 28, ISI4. Owing to more men and heavier guns on the part of the enemy, Captain David Porter, the American commander, was obliged to give the order to strike the colors.

At that, Benjamin Hazen, a Groton seaman (who, though painfully wounded, had remained at his post, and at the last had joined in the request to hand down the flag to save the wounded), bade adieu in hearty fashion to those around him, said he had determined never to survive the surrender of the Essex, and jumped overboard. He was drowned (III. 43, 44).

For several generations the name of Benjamin Hazen has been a familiar one in Groton. Heroes do not spring up, here or elsewhere, in such numbers that the town can afford to forget such a son, who long ago passed into obscurity. Hazen's name, numbered $\mathbf{r} 80$, is given in a list printed in the "Journal of a Cruise made to the Pacific Ocean" (Philadelphia, I8 I 5 ), by Captain David Porter. It is found on page 9 of the first volume, where he is rated as a "seaman"; and on page $\mathrm{I} 6 \mathrm{I}$ of the second volume it appears again in the list of those killed in action.

Benjamin Hazen was the third son and fourth child of Benjamin and Lydia (Woods) Hazen, and was born at Groton, on June I3, I 776. In talking with Luther Hazen, a nephew of the seaman, twelve years ago, I found that he was familiar with the facts connected with his uncle's tragic death. He told me that, according to family tradition, the old sailor weighted his pockets with heavy shot before he jumped overboard. Luther, the nephew, was a son of Edward and Esther (Cass) Hazen, and was born on December 27, 1820, at Groton, where he died on November 30, 1901, of heart disease, after an illness of two weeks. His mother was born at Richmond, New Hampshire. 


\section{BENJAMIN GARFIELD.}

Benjamin Garfield, an ancestor of President Garfield, was one of the original proprietors of Groton, where he owned a "ten-acre right." His name is found several times in the early records of the town. See the printed edition of the same (pp. 56, I 43, I 45, I 46, I 48, I 54), for allusions to him and to parcels of land situated in Broad Meadow and Pine Meadow, which he owned before the destruction of Groton by. the Indians, though he did not return permanently after the re-settlement. He was the youngest son of Edward, Jr., and Rebecca Garfield, and born at Watertown, where he died on November 28, I 7 I 7 , aged 74 years.

\section{THE NAME OF GROTON.}

THE town is indebted for its name to Deane Winthrop, a son of Governor John Winthrop and one of the petitioners for its incorporation. He was born at Groton in the County of Suffolk, England, on March I6, I622-3; and the love of his native place prompted him to perpetuate its name in New England. He stands at the head of the first list of Selectmen appointed by the General Court, and for a short time was probably a resident here. At the age of exactly 8 I years he died, on March 16, I 703-4, at Pullen Point, now within the limits of Winthrop, Massachusetts. I feel a special interest in his memory, as he and I were born on the same day of the month of March, throwing out the difference between Old and New Style of reckoning.

A few years before the settlement of the town Emanuel Downing, of Salem, who married Lucy, a sister of Governor John Winthrop, had a very large farm which he called Groton. It was situated in what was afterward South Danvers, but now Peabody, on the old road leading from Lynn to Ipswich, and thus named, says Upham in his "Salem Witchcraft," " in dear remembrance of his wife's ancestral home in 'the old country" " 
(I. 43). Downing subsequently sold it to his nephews John Winthrop, Jr., and Adam Winthrop, on July 23, I644, when he speaks of it as "his farme of Groton." The sale is duly recorded in the Suffolk Registry of Deeds (I. 57).

According to "The New England Historical \& Genealogical Register" (XXIV. 56 note) "for January, I 870, Graten (elsewhere in the text called Groton) was the name of a precinct in Roxbury. Here stood (I750) the 'Grey Hound,' a well known tavern, and a favorite resort of the Sons of Liberty, a few years later." It was a corruption of Greaton, the name of the man who kept the "Grey Hound " tavern in the neighborhood.

Mr. Grenville Lindall Winthrop, a descendant of Governor John, in modern times has given the name of Groton Place to his country seat at Lenox; and his younger brother, Mr. Frederic Winthrop, has given the name of Groton House to his country place at Hamilton.

The following item from the "Boston Daily Advertiser," September 6, I9I0, gives the latest intelligence in regard to the old manor house:

Groton Place, in Suffolk, England, where John Winthrop, first Massachusetts governor, was squire and patron of a church living before he and his son sailed for America in 1630 , is to be sold at auction this week. The old manor house has long been gone, a modern house occupying the place, which has been occupied by tenant farmers. The old church stands, and a sturdy mulberry tree from which numerous cuttings have been transplanted to New England.

The name of the town has proved to be so auspicious on this side of the ocean that it has been repeated in the States of Connecticut, New Hampshire, Vermont, Ohio, New York and South Dakota. With the exception of the town west of the Mississippi, I have visited them all, including the one in England.

In these several visits I have interested myself to learn the local pronunciation of the word. I have asked many persons in all ranks of life and grades of society in regard to the matter, and without exception they have given it "Gráw-ton," 
which every "native here, and to the manner born" knows so well how to pronounce. It has never been Grōw-ton, or Grǒt-ton even, but always with a broad sound on the first and accented syllable. Such was the old pronunciation in England, and by the continuity of custom and tradition the same has been kept up throughout the various settlements in this country bearing the name. The oldest form of the word is found in Doomsday Book, written in Latin more than eight hundred years ago. It there appears as Grotena, which by all analogy has a short penult.

\section{A "RAISING."}

IN former years in the country, when a house, barn, or other framed building was to be erected, it was the custom to have a "raising." On such occasions the neighbors used to meet and give their combined help in aid of the undertaking. In this way the framework of wooden buildings was set up in a short space of time.

The sills, beams and standards, duly cut by the carpenters, with mortises and tenons, were now ready to be put in position. Next in order was the placing of the various pieces of the frame where each one belonged, and fastening them with large wooden pins or pegs. The beams were heavy and the lifting them was hard, but with many men to lend a hand, the work was light. On such occasions a rude collation was always served, sometimes enlivened with cider and sometimes with rum punch. The day made a break in the monotony of country life; and everybody had a good time.

I remember the raising of George W. Bancroft's barn at the head of Love Lane, which took place - according to my recollection - in the year I 846 , when there was a large number of persons present.

I was a school-boy at the time, and was late at school in consequence of my attendance at the raising; and the whole affair made an impression on my youthful mind. 


\section{IVHITEFIELD.}

THE Massachusetts Historical Society has in its Library a copy of "Some Reasons Given by The IVestern Association Upon Mcrimack River, Why They disapprove of the Reverend Mr. George Whiteficld's preaching in the New-England Churches" (Boston, I 745).

The pamphlet is in substance the report of a meeting of the Association, held at Chelmsford, on February I3, I744-5, which was called to consider various objections that had been made to Mr. Whitefield as a preacher. One of the charges brought against him was that he was "enthusiastical, nncharitable, and destructive of the Pcace and Order of the Churches of this Land."

The last paragraph in the pamphlet is as follows :-

For these Reasons, and many other which have been made publick by others, we do unaminously agree, to give no Encouragement or Countenance to $\mathrm{Mr}$. Whiteficld's preaching or performing any Part of the Ministerial Office, in any of the Towns to which we stand related as their Pastors.

[signed]

Samuel Rugrgles, Pastor of the Church in Bellerica.

Caleb Trowibridge,

Thomas Parker,

II illard Hall,

Daniel Rogers,

David Stearns,

Fohn Rogers,

Fosiah Stean,

Ebenezer Bridge,
Groton,

Dracut,

Wesford,

Littleton,

Lunenburg.

Leominster,

Dunstable,

Chelmsford.

Rev. George Whitefield. - More than a hundred and fifty years ago George Whitefield was one of the most famous preachers in the English-speaking world. He was the son of an inn-holder, and was born in Gloucester, England, on December 27, I7 14. At an early period in his youth he began to write sermons, and otherwise to give tokens of his future career. He led a life of religious zeal and self-denial, and 
after graduating at Pembroke college, Oxford, he was ordained in the church. Soon afterward he came to America, where he attracted large audiences, calling them to repentance; and he swayed them as the winds do the forest trees. He was an effective speaker, and had a stentorian voice, which, according to contemporary accounts, could be heard a mile away. It is said that he preached to bigger crowds than ever listened to any other man; and it is related of him that once he addressed an audience of 20,000 persons on Boston Common. At one time Mr. Whitefield was closely associated with John Wesley and his brother Charles, but their relations became strained, and finally they separated. He had a falling out also with some of the New England ministry, as they did not altogether favor his methods; but he was a power in the land and did an immense deal of good in showing sinners the error of their ways. He made seven voyages to this country, and preached here thousands of times, and died suddenly on September 30, 1770, at Newburyport, where he lies buried.

The Reverend Caleb Trowbridge, who was ordained at Groton March 2, I 7I5, and remained there until the time of his death, on September 9, I760, did not sympathize with Mr. Whitefield's views.

According to the extract from "The Boston Gazette, or Weekly Journal," June I8, 1745, which is given below, Mr. Whitefield preached in the adjoining towns of Hollis, Townsend, Pepperell, Dunstable and Harvard, but he does not appear to have come to Groton, which at that time was the important centre of the neighborhood. From this fact I infer that his relations with Mr. Trowbridge were not close.

For about these twelve Days last past the Rev. Mr. Whitefield has been out of 'Town, in which Time he has preach'd once on a Fast Day on the Account of the Cape-Breton Expedition for the Rev. Mr. Emmerson at Malden; four Times for the Rev. Mr. Hobby of Reading; five Times for the Rev. Mr. Migregre of Londonderry; twice for the Rev. Mr. Emmerson of Nisitiscet [Hollis, N. H.]; once for the Rev. Mr. Hemmingzuay of Townshend; once at Groton Precinct [Pepperell] at a new Meeting-House; once at Litchfield; once at 
Timberlane [Hampstead, N. H.], once at Dunstable; twice for the Rev. Mr. Secomb of Harvard; once for the Rev. Mr Bliss of Concord; and once at the Seat of Isaac Royal, Esq; [Medford] . . . 'This Morning he return'd to Town, \& intends, God willing, to preach at five this Evening at the Rev. Mr. Webb's [of the New North], and to take his final Leave for this Season of Boston, one Day this Week.

Mr. Whitefield was an interesting character, and in this country he influenced the lives of thousands of persons; and the effect of his preaching in many families has been handed down from generation to generation even to the present day.

\section{HISTORICAL INSCRIPTIONS.}

ON February 20, I880, the town of Groton dedicated three monuments bearing the following inscriptions, which were written by President Eliot of Harvard College.

NEAR THIS SPOT

STOOD THE FIRST MEETING HOUSE OF GROTON

BUILT IN 1666

AND BURNT BY THE INDIANS

13 MARCH 1676

HERE DIVELT

WILLIAM AND DELIVERANCE LONGLEY

WITH THEIR EIGHT CHILDREN.

ON THE $27 \mathrm{TH}$ OF JULY 1694

THE INDIANS KILLED THE FATHER AND MOTHER

AND FIVE OF THE CHILDREN

AND CARRIED INTO CAPTIVITY

THE OTHER THREE.

\section{COLONEL WILLIAM PRESCOTT}

COMMANDER OF THE AMERICAN FORCES

AT THE BATTLE OF BUNKER HILL

WAS BORN ON THE 20TH OF FEBRUARY 1726

IN A HOUSE WHICII STOOD

NEAR THIS SPOT 
An oaken tablet was placed in the porch of the First Parish Meeting-house, which contains an inscription, as follows:-

$$
\text { First PARISH MEETING-HOUSE, }
$$

BUILT 1755,

REMODELED AND PARTIALLY TURNED AROUND 1839.

Here Were held ALl the TOWn Meetings from 1755 TO 1859: here also sat the Court of General Sessions of the Peace, and Court of Common Pleas FOR MIDDLESEx COUNTY FROM 1776 TO 1787 , as Groton was then one of the Shire Towns.

By invitation of the parish the exercises were conducted by the Groton Historical Society, on June I7, I899. The expense of the tablet was borne by Mrs. C. A. L. Sibley, and the words were written by the compiler of this volume.

In September, I8Io, a granite boulder was placed by the roadside, near the grounds of the Groton School, bearing the following inscription:-

\author{
HERE DWELT \\ JOHN DAVIS, \\ KILLED IN HIS OWN DOORYARD \\ BY THE INDIANS, \\ OCTOBER 25,1704 .
}

The stone was taken from the farm of Theophilus Gilman Smith in the immediate neighborhood, and the expense of the cutting was borne by William Amory Gardner. The inscription was written by the compiler.

\title{
FASHION IN GIVEN NAMIES.
}

IT is interesting to note the changes that have occurred in baptismal names within a few generations. During the early days of New England, certain names that now seem uncouth to the ear were common in every community. They were 
taken largely from the Bible, which was the only book universally read at that period. Zerubbabel Kemp was living in Groton at the beginning of the eighteenth century, and he gave the same name to one of his sons, who lived to grow up, notwithstanding the infliction. Mephibosheth Adams was a resident in the west parish of Groton a hundred and seventyfive years ago, - and tradition says that he was known among his neighbors as "Fib" Adams, — but he spared his own boys. A class of girls' names, common in the last century, and representing abstract qualities, such as Faith, Hope, Charity, Temperance, Prudence, and Virtue, have now become obsolete. The good old names of Molly, Polly, Dolly, and Sally are never seen in their original spelling. Susie is considered a better form than Sukey, and Bessie is preferred to Betty or Betsey. At the present time, however, there is a tendency to take up certain names long out of fashion, such as Dorothy, Rachel, Esther, etc., and to bring them again into vogue.

The name of Gabriel Lakin, of Groton, was kept up through several generations, and the name of Sibyl was in common use in the same family. John Frost, perhaps a kinsman of the well-known "Jack Frost," had among his twelve children one called Scripture, perhaps the maiden name of the mother. His eldest daughter was Jemima, and his three youngest children were named respectively Tryphena, Patience, and Submit.

\section{GROTON MILE-STONES.}

THE earliest legislation in this Commonwealth on the subject of guide-posts bears date February 28, I795. At that time an Act was passed by the Gencral Court requiring the selectmen of the several towns and districts, under certain conditions, to erect guide-posts at the corners and angles of all roads in such towns and districts; and imposing penalties for non-compliance with the law. Before that time, in a few towns, individuals had set up stones by the roadside, marking 
I60 NATURAL HISTORY AND TOPOGRAPHY OF GROTOŃ, MASS. the distance and direction to some important town; and these persons often added their own initials, as well as the year when the stones were placed.

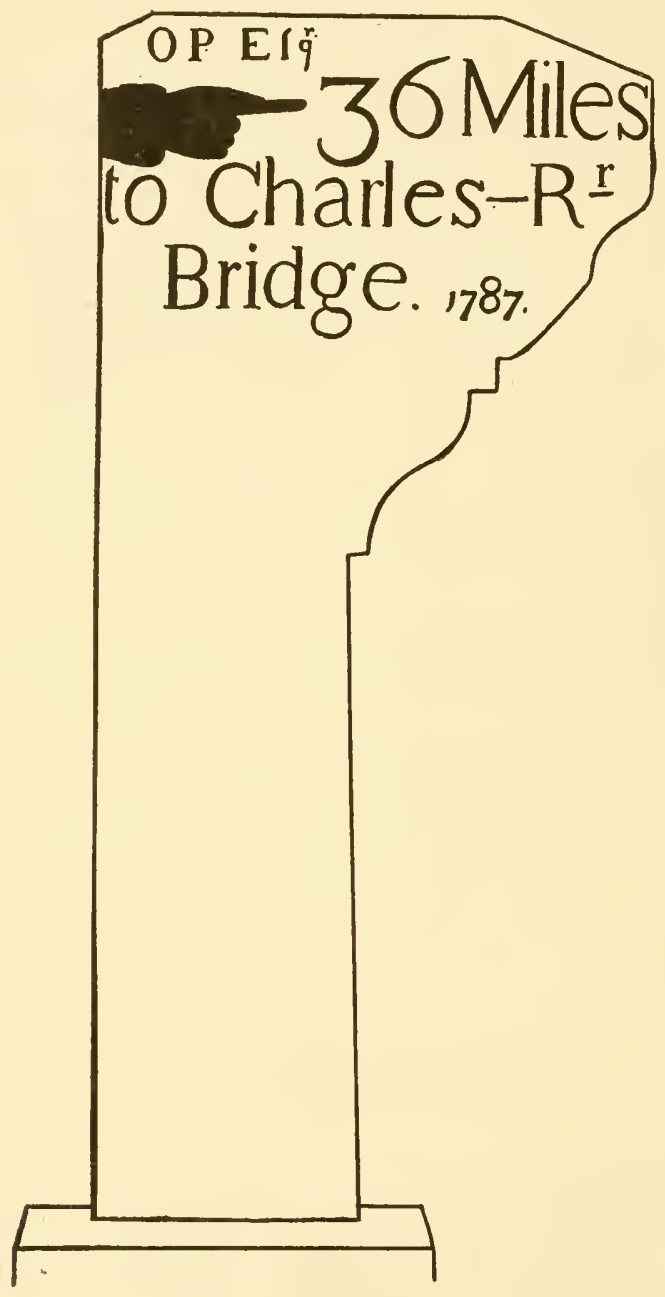

At the present time there are several mile-stones in Groton which were set up during the eighteenth century. Two of them certainly were placed by Dr. Oliver Prescott, younger 
brother of Colonel Villiam Prescott, who commanded the American forces at the battle of Bunker Hill; and two others were set up, probably either by him or at his suggestion, during the same period. They all are of slate; and the largest stands by the roadside, at the southerly end of the village street, on the easterly side of the way, near the fork of the roads and close by the entrance to Mr. Lawrence Park's estate. The stone is between five and six feet in height, and is shaped somewhat like a capital letter P of colossal size, the upper part being considerably broader than the lower part, though the resemblance is not very close.

The Charles River Bridge, leading from Boston to Charlestown, was opened on June I 7,1786 , and soon became a prominent point to people living in Middlesex County. Some vandal has tried to chip off "Esq" after the initials, but the letters can still be made out.

The Reverend William Bentley, D.D., of Salem, in his Diary, recently published by the Essex Institute, gives an account of a trip which he made to Dartmouth College in the summer of I793. On his way there he passed through Groton, and mentions this stone together with other entries in his journal which now are of interest. He writes:

We dined at Bollan's [in Chelmsford] \& paid Is /, our engagement being to have no charges for the horsemen \& his horses, \& at $\frac{1}{2}$ past 3 set out for Groton.... As we entered Westford we saw the best corn, \& the best tobacco, \& a few small hop yards. Corn being planted in all the farms \& a patch of tobacco near many of the barns. \& some towns through which we passed are remarkable for hops. - From the rough roads we passed over several miles of pines $s$ sandy land, \& soon were relieved with the elegant seat of G. [eneral Oliver] Prescot, \& the Buildings of his Son about $\frac{1}{2}$ mile below him. The seat is opposite to the Boston road which at this place enters into the cross road to Worcester. . . . Gen. Prescot house has near it a stone shewing that it is 36 miles to Boston \& 30 miles to Worcester. Called at the General's \& found an elegant House in good order, but he was not within (ii. $4 \mathrm{I}, 42$ ).

Another stone, about three feet high, stands in close proxinity, just beyond the crotch, on the westerly side of the road. 
On this stone, also, an attempt has been made to chisel off the word "Esq." The inscription reads:

\section{O. P. Esq.

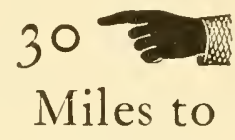 \\ Worcester}

\section{783}

A third stone, about three feet in height, stands near the Groton School, on the easterly side of Farmers' Rnw, at the south corner of Peabody Street, and was set up probably by Dr. Prescott. The top has been broken off, but the inscription remains, as follows:

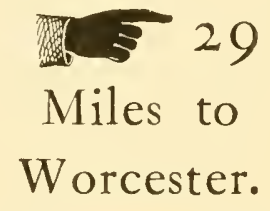

In front of the old tavern in the village, now known as the Groton Inn, is a fourth stone, belonging to the same period of time, standing out of the ground about a foot and a half, and perhaps set up by Dr. P'rescott, which bears these words:

\section{Tc}

Boston

\section{5}

On the north side of the Great Road to Boston there is a slate slab, about four feet in height, which bears the following inscription :

To

Boston 
The stone stands about a mile from the village, near Cady Pond, though probably not where it was originally placed. It is not known when or by whom it was put up; but probably the date goes back to the eighteenth century. The width near the top is about fourteen inches.

According to the guide-board at the north-west corner of the Common, the distance from Groton to Boston is thirty-four miles; and this is considered to be correct. In the years 1902 and 1903 the selectmen caused to be set up, on the several roads leading to the outer limits of the town, granite posts marking the distance of each mile from the Town-house. Twenty-eight such stones have been thus placed by the roadside for the benefit of the wayfarer; and they stand about two and a half feet out of the ground.

It may not be amiss here to note the fact that there was some lettering on a boulder formerly in an old wall that stood within a few rods of the mile-stone mentioned at the head of this article. It bears the initials of Dr. Oliver Prescott as well as those of his grandfather, who more than a century before had cut his own initials on the same stone. It is possible that this inscription in the old wall first suggested to Dr. Prescott the idea of erecting mile-stones in close proximity to the boulder. The inscription on the boulder is as follows:

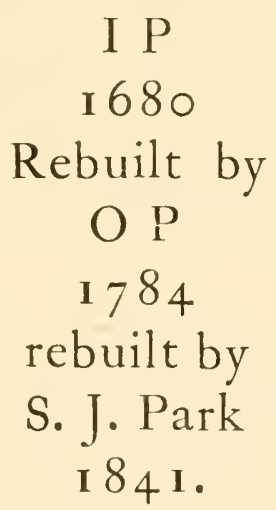

The initials I. P. are those of Jonas Prescott, - rudely cut, undoubtedly by himself, as he was a blacksmith, - and O. P. 
are those of his grandson I)r. Oliver Prescott. S. J. Park was Stuart James Park, the great-grandfather of Mr. Lawrence Park, who now owns the adjacent land.

Jonas Prescott was an active man in the affairs of the town, and the ancestor of a long line of distinguished families. He was the grandfather of Colonel William Prescott, commander of the American forces at the Battle of Bunker Hill, who was himself the father of William Prescott the lawyer and jurist, and the grandfather of William Hickling Prescott the historian.

In the year 1876 this piece of stone wall containing the boulder and separating a part of the Prescott house-lot from the highway was removed. Three years after it was taken away, I endeavored to find the stone, then to all intents and purposes lost; and it was a long while before I got any trace of it. The late Willard H. Giles, at that time the owner of the farm, knew nothing about it, and in fact had never seen it. I was told, however, that it might have been used in stoning up the cellar of a barn built in 1876 , and here I directed my search. With Mr. Giles's permission I employed two men for two days to take out and replace various stones, until the missing one was found. Subsequently I gave the memorial to Mr. James Lawrence, a lineal descendant of Jonas Prescott, who has had it set in the wall on the north side of his front gate on Farmers' Row, where it is likely to remain for many years.

It may not be amiss to give here the derivation of the word "mile," which comes from the Latin mille. With the Romans a mile was a thousand steps, or paces (mille passumm); and thus the word has come down to us in our daily speech.

\section{INSTANCES OF LONGEVITY.}

\section{Mrs. SARAH C. ROCKWOOD.}

While travelling homeward, through the state of New York, from a recent trip to the Southwest, I left the cars at Syracuse, on Thanksgiving Day (November 28), with the 
intention to call on MIrs. Rockwood; but on reaching Cortland I found that she had died on November 26. I was thus enabled to attend her funeral on the next day, and to follow her remains to the grave. It was a source of sad satisfaction to pay this last token of respect to the memory of one who had known my mother from her earliest infancy.

Mrs. Rockwood was the second daughter and fourth child of the Reverend Daniel and Susanna (Prescott) Chaplin, and was born at Groton, on November 8, I785. She was married, on May I, I828, to Abel, son of Samuel and Lucy (Hubbard) Rockwood, who died on November 21, I 828. She attended school at Groton Academy in the year 1797 under the preceptorship of Asahel Stearns.

The following account of the venerable lady, with an engraved portrait at the head of the article, is found in the "Cortland Standard," November 28, I8S9. In the reprint I have taken the occasion to correct some inaccuracies of statement.

Mrs. Sarah Chaplin Rockwood, whose portrait is published above and who was the oldest person in Cortland County, died Tuesclay afternoon, November 26. from pneumonia, at the advanced age of one hundred and four years. She was conscious nearly to the time of her death. Although up to a year ago Mrs. Rockwood had retained all her faculties, excepting hearing, to a remarkable degree, during the past few months her eyesight began to be seriously affected. Mrs. Theo. Chaplin Walton, of Chicago, her only near, relative, was with her during the last week of her life. 'To the last Mrs. Rockwood maintained a lively interest in the events of the day, and was an ardent Republican. For a number of years her home had been with Mrs. Samuel Bangs on Groton Avenue, and the funeral will be held there Friday afternoon at $\mathbf{2}$ o'clock. From a notice of Nrs. Rockwood published in the "Standard" at the time she celebrated her one hundred and third birthday, we reprint the following sketch of her life, furnished by Mrs. Walton :-

Mrs. Sarah Chaplin Rockwood was born Nov. 8, i 785, in Groton, Mass. Her father, the Rev. Daniel Chaplin, D.D., was a grandson of the Hugh Chaplin who settled in that part of Rowley which is now Georgetown, Mass., in 1639 . Several of the family lived to an advanced age, and Dr. Chaplin himself was eighty-six at the time of his 
death. On the mother's side, Mrrs. Rockwood was related to Col. Prescott of Bunker Hill fame, and her childhood memories took in the scenes and incidents of the Revolution with the same interest and enthusiasm that we have for the days of the Rebellion. There is today a large oid elm in the yard at the Chaplin homestead in Groton, Mass., set out by Mrs. Rockwood, when a little girl of seven or eight, on a rainy day after a cranberry expedition down in the swamp. She attended Groton Academy, and had as a schoolmate the late Amos Lawrence of Boston, who was a distant cousin. She often related with great animation their particularly good times at the monthly dances that were given at the close of school on the village common, and the "treats" of gingerbread handed around by the young men. She spent different years with her brother, Dr. James Prescott Chaplin, in Cambridgeport, who had the first private retreat for the insane in this country. She became a widow six months after her marriage to Mr. Abel Rockwood, and long after a half century she fondly cherished his memory. She spoke with a great deal of feeling of the visits paid her from time to time by the historian Prescott, who was as charming in manner as he was fine in mind. Advanced in years she came to New York State to be with her youngest brother, William L. Chaplin, who gave his life to the anti-slavery cause. He died in $\mathrm{I} 87 \mathrm{I}$, and is buried in your beautiful cemetery. It was a frequent saying of Mrs. Rockwood's that she belonged to a generation taught to preserve life as long as possible. She certainly put in use the precepts of extreme carefulness in the way of diet, exercise, and methodical habits. She was eminently loyal to the past, and never forgot a friend. She also believed in and loved the present, while she waited the coming of her Lord with a calm and cheerful heart.

A Vexerable Lady. -- Mrs. Rebecca Huse of Harvard, now ro6 years old, is probably the oldest person in New England. She was born at Groton, but moved to Harvard at the age of 15 . and has no near relative living except a single daughter, having buried a large family of children. This venerable relic of a bygone age still retains to a remarkable degree of perfection her sense of sight and hearing, being but slightly deaf, and is remarkably active, making her own fire in the morning, and attending through the day to a large part of her household duties. Till the present year she has kept and cared for a cow, and attended to some gardening.

"Daily Evening Traveller" (Boston), October 27, 1865. 
Mrs. Huse's maiden name was Parker; and she died at Harvard, on September I4, I\$69, at the age of IO4 years, 2 months, and 12 days, according to the records of that town, which say also that she was a daughter of Ebenezer and Dinah Parker, of Groton. Her parentage, as there given, is probably wrong. The only Rebecca Parker whose name is found on the Groton records, and whose age at all corresponds with that of the centenarian, is the eldest daughter of Oliver and Eunice Parker, who was born on November 22, I 760 ; while there is no entry of any Ebenezer and Dinah Parker. It is true that at that period the records are somewhat imperfect, and omissions of names are often found. Mrs. Huse outlived most of those who came immediately after her, as well as her own generation; and it would not be surprising if the returns made to the town-clerk at the time of her death were inaccurate. But the fact which has the most weight in deciding the question is the following incident, related to me by the late Reverend John Barstow Willard, of Still River, a long time ago, but which I did not try then to verify or corroborate.

Mr. IVillard told me, perhaps thirty years ago, that he never saw Mrs. Huse but once, and then she told him of a drowning accident that happened on the Nashua River, when she was four years old. It occurred on Election Day, and she could just recollect the event. Her account of the accident is singularly confirmed by the following item from "The Boston Post-Boy \& Advertiser," June 4, I764, a file of which newspaper I have examined with particular reference to this clew : --

Last Wednesday [May 3o, Election Day of that year] five Men going in a Canoe in Harvard [Nashua] River to catch some Fish, the Canoe sunk, and three of them were unfortunately drowned.

An occurrence attended with such fatal results would naturally leave a deep impression on a child's memory, and particularly in a small country town, where for a long time it would have been the subject of general conversation.

Another account of Mrs. Huse, taken from "The Fitchburg Sentinel," July 27 , I 867 , says that:- 
She remembers very clearly when her fatherstarted from home to join our army in the IVar of the Revolution, and recollects that he sometimes came back to stay a day or two with his family and sometimes sent back small presents to his little girl.

This account shows that her father was a soldier in the Revolution, which fact goes far to establish her parentage. According to a muster-roll among the Massachusetts Archives (XII. I74) in the State House, Oliver Parker was a First Licutenant in Captain Asa Lawrence's company of minutemen that marched from Groton to Cambridge, on April 19, 1775 , after the Lexington alarm.

Hon. Ezra S. Stearns, of Fitchburg, under date of April I I, 1907, writes me giving another instance of a Groton centenarian who was "Azubah Burt, born in Sudbury, May I 3, I 7 I I, daughter of John and Rebecca Burt (Burk). The family removed to Groton, where she married Phineas Farnsworth, and in 1776 married, secondly, Matthias Farnsworth. Matthias Farnsworth died in 1796 , and the Farnsworth Genealogy says that she died in ISI2, aged Ioo. If she died on May I3, ISI2, she was IOI. I fail to find any record of her death."

Oliver Elliot was the third child of Elias and Ruth (Lawrence) Elliot of Groton, where he was born on August 24, I 734. He was living at Mason, New Hampshire, as early as the year 1753 , and was married at Groton West Parish (now Pepperell), on January 19, I75S, to Mary Fisk; and they were blessed with eight children. The following account of him is taken from the address delivered by John Boynton Hill, Esq., at the Centennial Celebration of the Incorporation of Mason, on August 26, i 868 : -

Oliver was an active, industrious man, and in the early period of the settlement, both before and after the incorporation of the town, was frequently employed in the public business, and elected to offices in the affairs of the place and town. In the last years of his life he felt the hard hand of poverty, but never wore the garments of a town pauper. He also was a soldier of the Revolutionary army. He died in September, 1836 , aged one hundred and two years. He left numerous descendants residing in the town, and many who have sought out homes in other places (pp. 22, 23). 
Mrs. Sarah (Capell) Gilson died on Sunday, August 24, I 890, at the advanced age of 96 years, 9 months, and 4 days. She was a daughter of John and Mary (Perkins) Capell, and was born at Groton on November 22, I 797. She was a woman of marked character and full of early reminiscences; and with an excellent memory, her conversation always gave great delight to her listeners. On April I, I 856, she was married to Luther Gilson, who died on April 2, I859, aged 69 years. She attended school at Groton Academy in the year I808; and at the time of her death, she was the oldest person in town.

Mrs. Roselle Hazard, wife of Peter Hazard, the Groton colored centenarian, died at Groton on the 28 th of the last month. She never fully recovered from the excitement attending the celebration of her husband's one hundredth birthday. She was 98 years old, and had been married more than eighty years.

“Boston Morning Journal," September 20, I S79.

Death of a Centenarian. Peter Hazard, the colored centenarian of Groton, died on Wednesday last [November 10 ] and was buried on Friday. His one hundredth birthday was celebrated with a good deal of feeling by his friends and neighbors in the summer of I 879 . His wife never recovered from the excitement of the occasion, and she died a short time afterward at the age of 98 years. "Uncle Peter," as he was called, was born August 8, I 779, and was consequently more than ror years old at the time of his death. He lived during many years in the family of the late Deacon Samuel Lawrence, and was supported by some member of this family to the day of his death.

"Boston Morning Journal," Monday, November I 5, 1880.

Mr. William Kemp of Groton died on Monday last [September 28] at an advanced age of ninety-six. Mr. Kemp was born at Groton on May 8, 1789 , and began to drum in early boyhood. His first appearance in the public service was during the year 1805 , as drummer of the South Company of Groton, commanded by Luther Lawrence, Esq., afterward the Mayor of Lowell. He has been the father of nine children, and has had thirty grandchildren, thirty-three great-grandchildren, and one great-great-grandchild. During his boyhood Mr. Kemp knew Major Daniel Simpson, the veteran drummer, who celebrated his ninety-fifth birthday yesterday.

"Boston Evening Journal," Wednesday, September 30, I885. 


\section{INSTANCES OF LONGEVITY IN GROTON.}

SoxiE remarkable cases of longevity and of regular succession of deaths, during a single year, are given in the Groton "Spirit of the Times" for July 26, I848. The list was furnished by Mr. Butler, and is as follows:

Molly, widow of Amos Stone, died May i3, $18_{47}$, aged 94 years and I month.

Abigail, widow of John Lawrence, died July го, 1847, aged 93 years and 9 months.

Mary, widow of John Capell, died September 6, I 847 , aged 93 years, 4 months and 25 days.

Major Amos Farnsworth, died October 19, 1847, aged 93 years, 6 months and I day.

Elizabeth, his widow, died December II, I874, aged 90 years, 7 months and 24 days.

Lucy, widow of Deacon Samuel Rockwood, died May I2, I $\$ 48$, aged 90 years, 8 months and 23 days.

All these persons with the exception of Mr. and Mrs. Ca pell were natives of Groton, and each one of the six, at the date of death, was the oldest person in town.

\section{RAILROAD MEETINGS.}

THE following article is copied from the "Boston Courier," November 19, 1846. The meeting of conference was held at Hoar's tavern, then kept by Daniel Hunt; and the action there taken determined the site of the "Junction," which has since become the town of Ayer.

Railroad Meeting. A meeting was held on Monday [November 16], in Groton, of the friends of Stony Brook and Worcester and Nashua Railroads, for mutual conference in relation to the location of the roads. Several gentlemen were present from Worcester, Nashua, Pepperell, and Lowell, among whom was ex-Governor Davis, President of the Nashua and Worcester road. It was considered important 
by the friends of the Stony Brook road, that a junction should be formed with the Nashua and Worcester at a point where that road would cross or intersect with the Fitchburg road and if possible to avoid the necessity of using the Fitchburg. This desirable object can be obtained by running the Stony Brook up to near School-house No. I 2, in Groton. At this point it will also intersect with the Townsend and Peterboro' road, as well as with the Fitchburg. The whole distance from North-Chelmsford to this contemplated junction is about twelve miles, which would be the length of the Stony Brook road.

We now hope our citizens will take hold of this enterprize and build the road with as little delay as possible. The whole line of the Worcester and Nashua road is under contract, and it will be all graded by a year from next January. Such, we understand are their terms of contract. If the stock for the Stony Brook is now taken up, we may, in about a year and a half, have a continuous line of railroad from our city to Albany in the West, and Portland in the East, and with several other places which cannot fail to add vastly to our wealth and to the increase of business and population. - [Lowell Courier.]

The East Wilton and Groton Railroad, mentioned in the next paragraph, was incorporated by the New Hampshire Legislature, on July IO, I 846 , and was to extend from East Wilton to the State Line, where it was to connect with the Groton and East Wilton Railroad, which was incorporated by the Massachusetts Legislature, on March 25, I 845 . The railroad, however, was never built, as its importance was considerably modified by the subsequent construction of the Worcester and Nashua Road and of the Wilton road from Nashua.

East-I Wilton and Groton Railroad. At the first meeting of the Grantees and Associates of the East-Wilton and Groton Railroad Company, holden at Smith's Hall, in Brookline [New Hampshire], on Thursday last, Asa F. Lawrence of Pepperell was chosen President, and I. B. Sawtell, Clerk. Thomas Brown and I. N. Worcester of Hollis, Luther Tarbell of Pepperell, WW. Gilson and Isaac Sawtell of Brookline, Wm. Lovejoy of Milford, and Ephraim Hackett of EastIVilton, were chosen managers for the corporation.

\footnotetext{
"Boston Courier," Friday, October 23, 1846.
} 


\section{INSTANCES OF LARGE FAMILIES IN GROTON.}

THE following are some instances of large families in Groton between the years $I 700$ and $\mathrm{I} 800$. The maiden names of the mothers, so far as known, are given within parentheses.

Robert and Deborah Parker had sixteen children, and Jonathan and Ruth (Shattuck) Farnsworth had fifteen. Ebenezer and Abigail Blood, Joseph and Abigail (Sawtell) Parker, and Oliver and Sarah (Tarbell) Farnsworth were blessed, each couple, with families of fourteen children.

Mrs. Joseph Parker, named above, "left two Hundred or upwards of Children \& Grandchildren," according to the inscription on her gravestone. She died on February 19, I787, in the goth year of her age.

Jonas and Jemima (Holden) Green were the happy parents of ten children, all born within a period of less than eleven years, and among them were twins and triplets. By a second marriage, Jonas became the father of nine more children.

Elisha and Elizabeth (Adams) Rockwood were favored with thirteen children. Isaac and Priscilla (Dodge) Bowers, John and Ruth Frost, Jonathan and Esther (Shedd) Lawrence, Nathaniel and Elizabeth (Page) Nutting, John and Elizabeth (Nutting) Nutting, Joseph and Mary (Prescott) Stone, Captain John and Molly (Everett) Williams, and Nathaniel and Alice Woods were each the parents of twelve children.

\section{CELEBRATION AT GROTON, JULY 4, ISO\%.}

THE following account of a celebration at Groton by the Federalists, on July 4, I 808 , is taken from the "Columbian Centinel " (Boston), July 8, I 807 .

I do not understand the statement therein made, that John Stuart delivered the oration, as it was subsequently printed and bears the name of Samuel Dana as the author; and the two letters that passed between Mr. Dana and the Committee 
of Arrangements are given in the pamphlet and leave no doubt on the subject. Besides, the brief description of the performance, as given by the Centinel, points clearly to the printed address; and furthermore a caustic Review, three columns in length, which appears in that newspaper of August 29, ascribes it to Mr. Dana. Mr. Stuart, a native of Peterborough, New Hampshire, was then a law-student in the office of the Honorable Timothy Bigelow, of Groton, and afterward a nember of the Suffolk Bar; but perhaps, for some reason now unknown, the address was read by him. John Stuart was a son of Charles and Esther (Ferguson) Stuart, and was born on September 5, I 7 S2. He graduated at Williams College in the Class of I 804, and died in the year I 848. On June 29, I809, Mr. Stuart was married to Sarah Tayler, only daughter of James and Sarah (Farwell) Brazer, of Groton.

\section{AMERICAN INDEPENDENCE.}

THIS joyful and glorious anniversary was noticed by the Federal Republicans of Groton, and the towns in its vicinity, with that "feast of reason and flow of soul," which should ever be exhibited at the recollection of the transactions of ' 76 . The morning was welcomed by the usual artillery discharge of seventeen guns. At ro, A. M. a procession was formed, consisting of Clergymen, Civil and Military Officers, the Preceptor of Groton Academy with his pupils, and a numerous and respectable assembly of citizens of that and the towns adjacent, among whom were with pleasure distinguished many patriots and veterans, who had toiled to produce the event that occasioned the festivity of the day. The procession was escorted to the MeetingHouse by the Concord Artillery, under Capt. [Thomas] Heald, and a company of Infantry, under Capt. [Luther] LAwRENCE, of Groton. The Throne of Grace was devoutly addressed by the Rev. Mr. [Daniel] Chaplin, of Groton, and a number of admirable pieces of music were performed, after which an Oration was pronounced by JoHN StUART, A. B. a performance which displayed the talents of that gentleman by the beauty of its style and diction, his patriotism by the vigor and manliness of his sentiments. - He reviewed the deeds of those sages and heroes who obtained our Independence, and drew tears for the blood of those who fell in the contest; - he told "the 
tale of other times," "pleasant and mournful to the soul;" he pointed out the causes which had operated to the ruin of all other Republics and warned us, lest by listening to the hypocrisy of demagogues, we follow them in the path to destruction. After dinner the following toasts were given, accompanied by responses of artillery :

The Day we celebrate. - May its annual return find our beloved country free, prosperous and happy.

The memory of our revolutionary martys, who generously planted the tree of liberty, and watered it with their blood.

The memory of George WASHington. - Those must be his truest friends, who were so while he was yet alive.

The surviving Officers and Soldiers of the revolutionary army. May our respect compensate for the penurious reward with which their services were requited.

The American People. - May they ever remember that wisdom and virtue are as essential to preserve liberty, as they were to obtain it.

The Rising Generation. - Born free, may they never beget slaves.

Our Rights and Liberties. - Incapable of aberration, may they descend, like an estate tail, till time itself shall have no remainder.

The President of the United States. - In repelling foreign insult, may he find us all united.

The Governor of this Commonwealth. - In the exercise of his constitutional rights, he shall find a cheerful support from those, who did not elect him.

The Militia of this Commonwealth. - May they unite the freedom of citizens to the discipline of soldiers.

Caleb Strong. - May his private life be as happy, as his public has been meritorious.

Agriculture. - May our honest farmers never bow the knee to imposing despotism.

Massachusetts. - In the penumbra of democracy, may it not suffer a total eclipse, but soon emerge and regain its pristine splendor.

The Reverend Clergy. - As they well deserve, so may they freely receive our cordial attachment and support.

The memory of Col. William Prescott, and his Fellow Soldiers from the vicinity, whose gallant deeds on Bunker's hill first taught our enemies to respect American valor. 
The Fair Sex. - The tyrants of our affections, the only tyrants we will ever obey.

The next Fourth of July. - May it find us free, prosperous and happy.

\section{VOLUNTEERS.}

THE Officers and Soldiers of the Concord Artillery : Good men and true they must have been to have come so far, for so noble and glorious a purpose.

The Orator of the Day: Were we all as correct and well informed, our Country would never have occasion to blush for any of her sons.

The performances of the day were conducted with an unusual degree of decorum and propriety, united to a cheerful festivity. The citizens retired at an early hour, in order seasonably to prepare for the approaching day of rest.

\section{CELEBRATION AT GROTON, JULY 4, I808.}

THE following account of a Fourth of July celebration is found in the "Columbian Centinel," July I 3, I 808 . It took place under the auspices of the Federalists, and was perhaps prompted by a similar celebration of the Democrats on July 4, I807. At that period the two political parties in Groton were very evenly divided, though with a slight preponderance toward the Federalists, and partisan feeling ran high. Mr. Moore, the orator of the day, was a young lawyer of Groton, and later was postmaster of the town. The address of the preceding year was delivered by the Honorable Samuel Dana, another lawyer of Groton, who had previously been the postmaster, and it was subsequently printed.

\section{AT GROTON - MASS.}

THE rising sun was welcomed with the usual salute of I 7 guns -

a procession was formed, composed of the Rev. Clergy, Civil and Military Officers, the Preceptor and Students of the Academy, and a numerous collection of citizens of Groton, and adjacent towns ; which was escorted to the Meeting-House by the Concord Artillery under Capt. Churchill, a platoon of the Groton Artillery, under Lt. 
Carleton, ${ }^{*}$ and a company of Infantry, commanded by Capt. [Luther] Lawrence. The Rev. Mr. Chaplain [sic] made a devout and fervent prayer; several excellent pieces of music were performed; and an elegant, spirited and patriotic Oration was delivered by ABRAHAM MoORE, A. B. At table the following toasts were given, and echoed by discharges of artillery :-

I. The day zee celebrate - The monarch may forget he sway's a sceptre; the prisoner that he wears a chain; but an American will never forget the $4^{\text {th }}$ of July.

[Hail Columbia.

2. GEORGE WASHINGTON-whose memory is embalmed in the hearts of his countrymen. May his principles and example be venerated by his successors. [Washington's March.

3. The Statesmen and Warriors of our Revolution. Gratitude to the surviving; to the departed, peace.

[Dirge.

4. The Militia of our Country - The palladium of our liberties; alike ambitious to adorn the character of the citizen and soldier.

[Soldier's Foy.

5. Massachusetts - Convalescent from a short fit of democratic mania ; of a sound heart and strong constitution ; but a little giddy in the head.

[Crazy Fane.

6. Governor SULLIVAN. - In discharging the functions of his office, may he listen to the advice of his Council.

[Oh! listen then.

7. Commerce - May the oaks of our forests soon be converted into 74's, to protect it from its zeorst enemies, the invincible gun-boats.

[Here a sheer hulk, Soc.

8. Agriculture, the twin sister of Commerce - The " unseen hand" that rudely violates the one, despoils the other.

[Speed the Plough.

9. The Times - May they open the eyes of the blind.

[Devil's Dream.

Io. Office seekers - Abundance of bread and fish to all, who sacrifice their principles, for the loaves and fishes.

[Nothing but a place.

* Capt. [James] Lewis, of the Groton Artillery, (a demo.) tho courtecusly invited to appenr with his company to celebrate the day, which gave our country birth, not only meanly denied Lient. [SOLOMON] CARLETON and his company' the use of the cannon on the occasion, but unsuccessfully endeavored to dissuade many from the celebration. 
I I. The Sun of Federalism - The northern limb just emerged from an eclipse by the moon of Democracy - may we soon behold its whole disk in original splendor.

[Lucky Escape.

12. The American Eagle - May he wing his way undisturbed by crowing of the Gallic Cock, or the roaring of the British Lion.

[Federal March.

13. The speculations of modern Philosophy - Harmless when planning dry docks, and describing salt mountains; but destructive when contriving embargo laws. [The heavy hours are almost past.

I 4. Col. PICKERING, the Daniel of Massachusetts. - He has weighed Belshazzar in a "balance," and verily the King is "found wanting."

[Kick the beam.

15. FOHN QUINCY ADAMS- "Elections are the test of confidence, and their periodical return a check on its abuse."

[I'll set me dozen and cry.

I6. The memory of Col. WM. PRESCOTT, and the brave officers and soldiers of this vicinity; who on the heights of Charlestozen, first taught British veterans to respect American valor.

[Gen. Green's March.

17. The reverend Clergy - May the diffusion of piety and virtue, the object of their care, be the reward of their exertions.

[Adams and Liberty.

\section{VOLUNTEERS.}

I. The Orator of the Day-Our hearty thanks for his oration - elegant in style, glowing in sentiment, dignified in principle.

2. The Officers and Soldiers of the Concord Artillery - Were all our citizens as generous, magnanimous and brave, we should never want cannon to proclaim our festivity, or to repel an invader.

3. The American Seamen - Turned adrift, and tossing on the ocean of distress, without ballast or provisions - may they find safety and succour in the haven of Federalism.

4. The NEXT fourth of Fuly - May it find us free, prosperous, and happy.

Harmony in sentiment prevailed, the strictest decorum was observed, and festive joy gladdened every heart. 


\section{LIST OF INDIAN WORDS.}

THE following Indian names, applied by the early settlers to streams, ponds, or places in the original township of Groton and neighborhood, for the most part are still in common use. The spelling of these words varies, as at first they were written according to their sound and not according to their derivation. In the absence of any correct standard either of spelling or pronunciation, which always characterizes an unwritten language, the words have become so twisted and distorted that much of their original meaning is lost; but their root generally remains. It is rare to find an Indian word in an early document spelled twice alike. In the lapse of time these verbal changes have been so great that an Indian now would hardly recognize any of them by sound. Even with all these drawbacks such words furnish one of the few links in a chain of historical facts connecting modern times with the prehistoric period of New England. As the shards that lie scattered around the site of old Indian dwellings are eagerly picked up by the archrologist for critical examination, so these isolated facts about place-names are worth saving by the antiquary for their philological value. "Gather up the fragments that remain, that nothing be lost."

Babbitasset - formerly the name of a village in Pepperrell, now included in East Pepperell.

Baddacook - a pond in the eastern part of the town.

Catacoonamug - a stream in Shirley, which empties into the Nashua.

Chicopee - a district in the northern part of the town, and applied to the highway approaching it, called Chicopee Row.

Humhaw - a brook in Westford.

Kissacook - a hill in Westford.

Massapoag - a pond lying partly in Groton and partly in Dunstable.

Mulpus - a brook in Shirley.

Nagog - a pond in Littleton.

Nashoba - the old name of the Praying Indian Village in Littleton, now applied to a hill in that town as well as to a brook in Westford.

Nashua - a river running through the township, and emptying into the Merrimack. 
Vaumox-a district, near the Longley monument, lying west of the East Pepperell road; said to have been the name of an Indian chief.

Nissitisset - applied to the neighborhood of Hollis, New Hampshire, and to a river and a hill in Pepperell.

Nonacoicus - a brook in Ayer, though formerly the name was applied to a tract of land in the southerly part of Groton, and is shortened often to Coicus. Major Simon Willard's place was sometimes called Nonacoicus farm; and his house was the first one burned in the attack by the Indians on the town, March $13,1676$.

Nubanussuck - a pond in Westford.

Petaupaukett - a name found in the original petition to the General Court for the grant of the town, and used in connection with the territory of the neighborhood; sometimes written Petapawage and Petapaway.

Quosoponagon - a meadow "on the other side of the riuer," mentioned in the land-grant of Thomas Tarbell, Jr.; the same word as Quasaponikin, formerly the name of a tract of land in Lancaster, but now given to a meadow and a hill in that town, where it is often contracted into Ponikin.

Shabikin, or more commonly Shabokin, applied to a district in Harvard, bordering on the Nashua, below Still River village.

Squannacook - a river in the western part of the town flowing into the Nashua; a name formerly applied to the village of West Groton.

Tudmuck - a brook and a meadow in IVestford.

Unquetenassett, or Unquetenorset - a brook in the northerly part of the town; often shortened into Unquety.

Waubansconcett - another word found in the original petition for the grant of the town, and used in connection with the territory of the neighborhood.

The following letter from the late Honorable James Hammond Trumbull, whose authority on matters of Indian philology was unquestioned, gives the meaning and derivation of the original name of the town:-

HARTFORD, Dec. 22, I 877.

My dear Dr. Green, - Petaupauket and Petapazeage are two forms of the same name, the former having the locative postposition $(-e t)$, meaning "at" or "on " a place; and both are corruptions of one 
or the other of two Indian names found at several localities in New England. From which of the two your Groton name came, I cannot decide without some knowledge of the place itself. I leave you the choice, confident that one or the other is the true name.

"Pootuppog," used by Eliot for "bay," in Joshua, xv. 2, 5, literally means "spreading" or "bulging water," and was employed to designate either a local widening of a river making still water, or an inlet from a river expanding into something like a pond or lake. Hence the name of a part of (old) Saybrook, now Essex, Conn., which was variously written Pautapaug, Poattapoge, Potabauge, and, later, Pettipaug, Sc., so designated from a spreading cove or inlet from Connecticut River. Pottapoug Pond in Dana, Mass., with an outlet to, or rather an inlet from, Chicopee River, is probably a form of the same name. So is "Port Tobacco," Charles County, Md. (the "Potopaco" of John Smith's map), on the Potomac.

But there is another Algonkin name from which Petaupauk and some similar forms may have cone, which denotes a swamp, bog, or quagmire, - literally, a place into which the foot sinks; represented by the Chippeway petobeg, a bog or soft marsh, and the Abnaki potepaug. There is a Pautipang (otherwise, Pootapang, Portipang, Patapogue, Sc.) in the town of Sprague, Conn., on or near the Shetucket River, which seems to have this derivation.

If there was in (ancient) Groton a pond or spreading cove, connected with the Nashua, Squannicook, Nisitisset, or other stream, or a pond-like enlargement or "bulge" of a stream, this may, without much doubt, be accepted as the origin of the name. If there is none such, the name probably came from some "watery swamp," like those into which (as the "Wonder Working Providence" relates) the first explorers of Concord "sunke, into an uncertaine bottome in water, and waded up to their knees."

Yours truly,

J. Hammond Trumbull.

The last suggestion, that the name came from an Algonkin word signifying swamp, or bog, is probably the correct one. There are many bog meadows, of greater or less extent, in different parts of the town. Two of the largest - one situated on the easterly side of the village, and known as Half-Moon Meadow, and the other on the westerly side, and known as Broad Meadow, each covering perhaps a hundred acres of land 
- are now in a state of successful cultivation. Before they were drained and improved, they would have been best designated as swamps, or bogs.

\section{PRINCE EDWARD'S VISIT.}

THERE is a tradition, familiar to the older inhabitants of the town, that Prince Edward, afterward Duke of Kent and the father of Queen Victoria, in the early part of I 794, passed through Groton on his way from Canada to Boston. He is said to have tarried over night at the old Richardson tavern, which in its day was a famous hostelry and stood on the spot where the Baptist meeting-house now stands. One account says that he was kept there for two or three days by a snowstorm. Converse Richardson, the landlord, died, according to his tombstone, on March 8, I 794 , which was only a month after the Prince's visit; and this fact tends to confirm the tradition that it was Mrs. Richardson who received the royal guest on his arrival at the inn. A bit of gossip and scandal has come down to the present time, connecting the good name of a Groton maiden with that of the royal traveller, which is hardly proper to be repeated here. In former years I have heard it from so many different sources that I am inclined to think there is some foundation for the story.

Prince Edward had been stationed at Quebec, in command of a regiment, when he received an appointment to serve in the IVest Indies, and at once left Canada. He travelled in some style, accompanied by his aids and body-guard, and crossed Lake Champlain on the ice, where two of his sledges broke through and were lost. He stayed at Burlington during two or three days, and then left for Boston, where he arrived on February 6, I 794. The "Columbian Centinel," February 8, says :-

On Thursday last, Prince EDward, son of his Britannic Majesty, arrived in this town from Quebec. We are told that his Highness has lately been promoted to the rank of Brigadier General, and is to have a command in the army in the West-Indies. 


\section{LAWRENCE ACADEMY.}

DURING the early part of the year I 792 a voluntary association was formed at Groton, by certain people of the town and neighborhood, in order to establish an Academy where a higher education could be obtained than was given in the district schools of that period. A subscription paper was circulated for the purpose of procuring funds to erect a suitable building. A subscription of five pounds currency was the smallest sum received from any person, and was denominated a share; ten pounds were called two shares; and so on. A complete list of the subscribers has never been printed, but a partial one appears in Mr. Butler's History of the town (p. 229). On April 27, 1792, the association organized by choosing trustees and the other customary officers; and from this as a beginning sprang the institution known formerly as Groton Academy, but now as Lawrence Academy.

The following is a copy of the original paper that bears the autograph signatures of the subscribers. The paper belongs to James Lawrence, of Groton, and was bought at the sale of the library of the late Reverend Andrew Bigelow, D.D., which took place in Boston on July 10-12, 1877. In the sale catalogue it was numbered 32 I among the " autographs," on page 49 of the pamphlet.

In Order to diffuse useful knowledge and render the means of In. struction \& information more general \& less expensive to Individuals, We agree to raise by Subscription in Shares at five pounds Each, a sum of Money for the purpose of Erecting a Suitable building for an Academy in the Town of Groton, within sixty Rods from the Public Meeting house of the first Parish in said Town, and severally promise to pay the sums annexed to our respective names, to such persons as shall be chosen by a Major Vote of the Subscribers to receive the same, upon a Meeting of the whole being duly warned so soon as Conveniently may be, after Sixty Shares are subscribed - And we further agree, that the Surplusage of the Money Subscribed after Compleating of said building, shall be applyed to the support of a proper Instructor or Instructors of said Academy, furnishing a Suitable Apparatus or whatever Else shall be most Conducive to the promoting of Educa- 
tion - And if the sums subscribed exceed the purposes aforesaid, they shall be disposed of by a Major Vote of the Subscribers - And it is further agreed that all Matters Relative to said Academy shall be determined by a Major Vote of the Subscribers, and the Vote to be taken by Shares

And in Case that hereafter said Academy should be dissolved each Subscriber or his heirs shall receive his Dividend of the Common property if any should remain in proportion to the Sum Subscribed

Groton March $26^{\text {th }} 1792$

\begin{tabular}{|c|c|c|c|c|c|}
\hline Oliver Prescott & three shares & • & • & - & $£_{15}-$ \\
\hline Benja Bancroft & three shares & . & • & - & I5 - \\
\hline Dan! Chaplin & one share & - & - & - & $5-0-0$ \\
\hline Vill" Swan & one share & . & 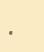 & . & $5 \cdot 0-$ \\
\hline Toseph Rockwood & one Share & $\cdot$ & . & - & $5-0-$ \\
\hline Nathan Davis & Two Shares & . & . & - & $10-0-0$ \\
\hline laron Brown & Three Shares & 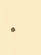 & - & . & I $5-0-0$ \\
\hline Tonathan Keep & two Shares. & . & & • & $10-0-0$ \\
\hline Sam! Lawrence & Two - D2. & . & - & . & so. o * \\
\hline am! Rockwood & Two - D?. & . & & . & Io ${ }^{\prime} 0{ }^{\prime} \circ$ \\
\hline amuel Gragg & One Share & - & & 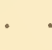 & $5 \circ 0$ \\
\hline Jeph Richardson & two sh- & . & . & 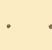 & $10-0-0$ \\
\hline Oliver Prescott J11. & Three Shares & . & . & 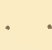 & I $5 \cdots \circ \cdots$ \\
\hline Thomas Gardner & Three Shares & . & • & .. & $15-0-0$ \\
\hline Francis Champney & two shares & • & . & . . & $10-0 \cdots 0$ \\
\hline amuel Dana & two Shares & . & . & . & $10 \cdot 0-$ \\
\hline Timothy Bigelow & three shares & . & . & 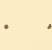 & 15.0 .0 \\
\hline James Brazer & three shares & . & & · & $15: 0=0$ \\
\hline Nehemiah Tarbell & one share & . & - & - & $5: 0: 0$ \\
\hline saac Bowers & one Share & $\cdot$ & . & . & $5-0-0$ \\
\hline $\mathrm{V}_{\mathrm{m}}^{\mathrm{m}}$ Prescott & Two shares & . & 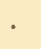 & - & $10 \cdots 0 \cdots 0$ \\
\hline Levi Kemp & one Share & . & . & . & $5: 0: 0$ \\
\hline$W_{\%}^{m}$ Bancroft & one Share . & $\cdot$ & - & · & $5: 0: 0$ \\
\hline Joseph Moors & Two Shares . & · & . & . & $10-0-0$ \\
\hline Zechariah Fitch & 'Two Shares. & . & . & - & $10-0-0$ \\
\hline Jonas Stone & one Share & . & . & . & $5-0-0$ \\
\hline Jonathan Fisk & one Share & . & . & . & $5-0-0$ \\
\hline mson Woods & one Share & . & $\cdot$ & . & $5: 0: 0$ \\
\hline amuel Hemenway & one Share & $\cdot$ & - & · & 5.0 .0 \\
\hline oseph Sawtell 3 rd & one Share & . & . & & $5=0-0$ \\
\hline
\end{tabular}


I84 NATURAL HISTORY AND TOPOGRAPHY OF GROTON, MASS.

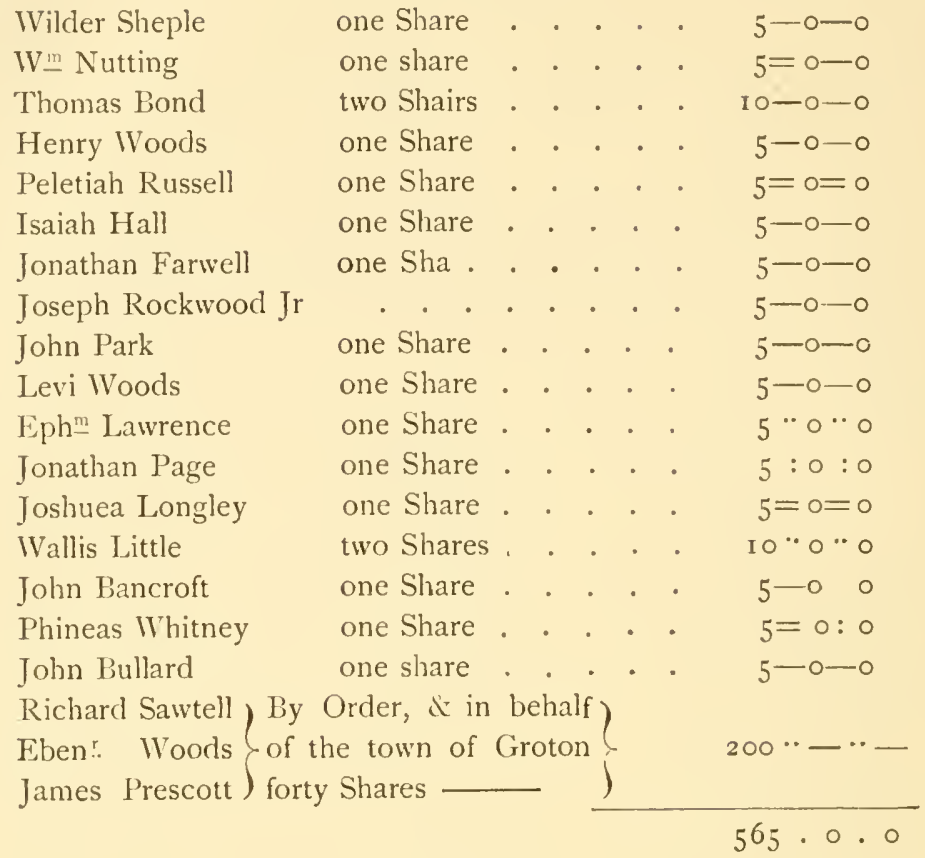

\section{REFLECTION OF ILIGHT.}

THE reflection of the electric light in Boston and the surrounding towns can be seen from certain elevations at a great distance. When the atmospheric conditions are favorable, it is distinctly visible on particular nights, from Indian Hill at Groton, in the neighborhood of Captain Moses Poor Palmer's house, and from other places in the town. A slight haziness in the air is needed in order to receive the reflection. The distance from Boston to Groton in a straight line is about 30 miles, though the illumination is helped by the electric systems of Newton and Waltham, which are somewhat nearer. From different points in the village of Groton the reflection of the circuits at Nashua, Lowell, Clinton, and Fitchburg is often visible, which places are 12 or 13 miles distant as the crow flies. 
The illumination of the heavens during the great fire that occurred in Boston, on the night of November 9, 1872, was distinctly seen by various persons in different parts of the town.

\section{AN AFFLICTED FAMILY.}

John Shattuck and his eldest son John, a young man nineteen years of age, were killed by the Indians at Groton, on May 8, I709. They were returning from the west side of the Nashua River and were attacked just as they were crossing Stony Fordway, near the present site of the paper mills, where they were killed. John Shattuck was the eldest child of John and R!th (Whitney) Shattuck, of Watertown, where he was born on June 4, I666. He married Mary, eldest daughter of James and Elizabeth (Longley) Blood, who was born at Groton on September I, 1672. Mr. Shattuck was a farmer, as everybody else was at that time. He owned land on the Nod Road which leads to the Four Corners below the soap-stone quarry. During the autumn of I 882 Messrs. Tileston and Hollingworth, of Boston, at that time the owners of the mill, caused a suitable stone to be placed by the wayside, bearing the following inscription:

NEAR TIIIS SPOT

JOHN SHATTUCK,

A SELECTMAN OF GROTON,

AND

HIS SON JOHN

WERE KILLED BY THE INDIANS,

MAY 8, 1709,

WHILE CROSSING STONY FORDWAY,

JUST BELOW THE PRESENT DAM.

I882.

By an oversight this inscription was not given in connection with the "Historical Inscriptions" on pages I 57 , 58. 
A remarkable fatality seenis to have followed Mrs. Shattuck's kindred. Her husband and eldest son were killed by the Indians, as has just been mentioned. Her father, James Blood, was likewise killed, September I3, I692. So also were her uncle, William Longley, his wife and fivè children, July 27, I 694; and three others of their children were carried away into captivity at the same time. A relative, James Parker, Jr., and his wife were killed in this assault, and their children taken prisoners. Her step-father, Enosh Lawrence, received a wound in an engagement with the Indians, probably in the same attack of July 27 , I 694, which almost wholly prevented him from earning a livelihood for himself and family. The name Enosh is a variation from Enos, and not from Enoch, with which it is frequently confounded. This will be seen by consulting the Geneva version of the Bible, long used in preference to King James's version, by the New England men, and out of which Enos Lawrence was undoubtedly named. In this "Enosh" will be found where the authorized version has "Enos," in Genesis v. 6, 7, 9-I I. The three Tarbell children, who were carried off to Canada by the Indians, June 20 , I 707, were cousins of Mrs. Shattuck. John Ames, who was shot by the savages at the gate of his own garrison, July 9 , I 724, was the father of Jacob, who married her niece, Ruth Shattuck. And lastly, her son-in-law, Isaac Lakin, the husband of her daughter Elizabeth, was wounded in Lovewell's Fight at Pequawket, May 8, I 725. These calamities covered a period of only one generation, extending from the year I 692 to 1725 .

\section{THE MINISTERS AT GROTON, IMMEDIATELY} AFTER MR. DANA'S DISMISSAL.

IT is well known that the Reverend Samuel Dana, the minister at Groton for fourteen years before the Revolution, was not in sympathy with the patriots when the war broke out. In fact, the feelingagainst him among his parishioners was so 
strong, on account of his political views, that he was dismissed from his charge, on May 15,1775 . In early times it was considered a public calamity for a town to be for many weeks without a settled preacher of the gospel; and steps were taken at once to fill the vacancy, or rather to supply the pulpit temporarily. In the church records there is no entry between June 8, I775, and September 5, 1777; and little is known now in regard to the affairs of the society during that period. Only from occasional diaries and other informal writings do we catch glimpses of what happened; and from such sidelights we gather a few additional facts.

IVithin a short time there has been published in "The American Historical Review" for January, Igor, a diary kept by the Reverend Samuel Cooper from April 19, I775, till May 17, 1776. He was the minister settled over the Brattle Square Church in Boston; but while that town was in the possession of the British, he was living, first at Weston and then at Waltham, often supplying the pulpit in various towns of the neighborhood. From the diary (pp. 306-322) it appears that during this period Mr. Cooper preached for several Sundays in Groton; and the different entries which relate to those occasions are given below:

Friday, May 5. . . . D $\mathrm{D}^{\mathrm{r}}$ Prescot of Groton visited me this morning and propos'd my Supplying their Pulpit, propos'd to Mr Woodward his going there and that I w'd supply his Pulpit wch he c'd not comply with. ...

Saturday. 13. May. Went to Concord with Mr Savage. call'd at Mr Hubbard's: f'm thence to Mr. Emerson's. He was abroad, engag'd to pch for him on the Morrow, while he was to supply Groton. return'd to Mr Savages, we din'd there. . . .

Lord's day. 2T. May. pch'd all day at Concord $\mathrm{M}^{\mathrm{r}}$ Emerson for me at Groton. din'd at his house. . . .

May 27. Saturday. Sat out in the Morn $5.8{ }^{\circ}$ Clock in my Chaise for Groton, bated at White's of Acton din'd at $\mathrm{M}^{\mathrm{rs}}$ Newman of Lyttleton. drank Coffee with $\mathbf{M I}^{\mathrm{r}}$ Rogers reach'd Groton at Sunset; Slept and Horse kept at $\mathrm{D}^{\mathrm{r}}$ Prescot's.

28. Lord's day. Pch'd all day at Groton; spoke with Mr Dana after Service a. m. din'd at D'r Prescot's baptiz'd a child P. M. 
slept and Horse kept at $D^{r}$ Prescot's. a brave Action of our Army this day at Noddle's and Hog Islands.

20. Monday. Sat out for Groton $S^{\circ}$ Clock. stop'd at $\mathrm{M}^{\mathrm{r}}$ [Willard] Hall's Wesford. saw $M^{\mathrm{ris}}$ Gray and Family there. proceeded to chalmsford. . . .

[Fune] II. Lord's d. Pch'd all day at Billerica, baptiz'd i. din'd and slept at $\mathrm{M}^{\mathrm{r}}$ Cummins. Visited in the Evg by Col Thompson and $D^{r}$ Danforth. $\mathrm{M}^{\mathrm{r}}$ Cummins pch'd for me at Groton. He sat out on Saturday before I arriv'd, and return'd home this Evening.

Fuly $r$. Went early to visit $\mathrm{M}^{\mathrm{rs}}$ Newell and Payne's Family. at Mr Brook's : not at home. proceeded for Groton. bated at Hartwell's gratis. Din'd at $D^{r}$ Lee's : Concord. His son obligingly accompanied us towards Lyttleton. Coffee at $\mathbf{M}^{\mathrm{rs}}$ Newman's. slept there. Horse at $\mathrm{M}^{\mathrm{r}}$ Tuthill's gratis.

2. Lord's day. Went early to Groton after Breakfast. pch'd all day. read Proclamation from Continental Congress for a Fast thro all the Colonies and f'm Pr. Congress respecting Sabbath. spoke extempore a few minutes upon the last. Din'd. Coffee, slept, and Horse at Dr Prescotts.

3. Monday. Visited by Capt. Sartell Dr Prescot had my Horse shoed at his own Expence. Came by Mistake the Westford Road to Concord. . . .

[October] I8. Wednesiay. Went my $\mathrm{H}$. and Ch. to Watertown. saw $D^{r}$ Prescot who paid me $60 £ O$. Ten ${ }^{r}$. for six Sabbaths at Groton. We Din'd at Deacon Fisk's. ...

According to Amos Farnsworth's diary, one Mr. Bigelow was supplying the pulpit at Groton, as early as December I I, 1775 ; and, according to the same authority, he appears to have preached there at frequent intervals for six months. On September 2, I 776, the town concurred with the church to hear Mr. Chaplin and Mr. Bigelow for four Sundays as candidates; and, on December 16 following, the town voted to concur with the church in the choice of Mr. Chaplin as the pastor. The votes, as recorded, do not give the Christian name of either candidate. Of course, the baptismal name of Mr. Chaplin is well known, as he remained in town during more than fifty years, until his death on April 8, I 83I. The given name of $\mathrm{Mr}$. Bigelow is learned with considerable certainty by inference. In the year 1774 there was a Mr. Isaac 
Bigelow preaching at Holden, who received a call to be settled over the church there, but he did not accept the invitation. Without much doubt he was the same person who a year later was preaching at Groton, as at that period most of the ministers were graduates of Harvard College.

Isaac Bigelow was the seventh child of Abraham and Abigail (Bullard) Bigelow, and was born at Weston, on May 2, 1750 . He graduated at Harvard in the class of 1769 , studied for the ministry, but never was ordained. His death took place on April I7, I777, at so early an age that he did not become prominently identified with any church. While his father wrote the surname "Bigelow," he himself dropped the middle letter, writing it "Biglow"; and thus the name appears in the Quinquennial Catalogue of the College.

\section{A TRIP FRON WORCESTER TO LOWELL.}

THE following extracts are taken from "The Massachusetts Spy, and Worcester County Advertiser," June I I, I828. They give an account of a trip from Worcester to Lowell, made by the editor of that newspaper (John Milton Earle), and they contain allusions to events of a long time ago, which will be interesting to the present generation. The "institution of some note for the education of females," mentioned therein, was Miss Susan Prescott's school for girls, which in its day had a wide reputation. According to a catalogue printed in the year I 826, there were then 102 scholars in the institution, and they came from far and near. There may be a few persons in town, but certainly not many, who still remember the theological controversy referred to, which raged at that period between the two religious societies.

On a pleasant morning, a few days since, we found ourselves comfortably seated in one corner of the Worcester and Lowell stage. Whether it was the mail line or accommodation, can be of no possi- 
ble consequence to our readers, for both, we believe, furnish good accommodations, and, such is the competition between them, that they both carry passengers from Worcester to Lowell, a distance of 46 miles, for one dollar. With the same money a horse may be hired in Worcester to go eight miles, or a horse and chaise to go about five miles. This low rate of stage fare has a tendency to increase travelling, so that, although two lines run on the same day, both generally are well filled with passengers. . . .

After changing horses we again pursued our journey through Shirley, a town noted for nothing in particular but a small settlement of Shakers, and arrived at Groton in season to dine.

Groton is a rich and pleasant agricultural town, the seat of an academy, and of an institution of some note for the education of females. The peace and harmony of the town have recently been much disturbed, by a bitter and acrimonious theological controversy, which has led to a division of the old society, and the establishment of a new one. The inhabitants have heretofore anticipated that it might become the shire town of a new county, to be formed from towns taken from the counties of Middlesex and Worcester. At present, there does not appear to be much prospect of realizing their anticipations. Too much importance, we apprehend, is generally attached to the circumstance of a town being the shire of a county. If it does not possess the other requisite advantages for a place of business, merely being a shire town can never make it flourish, and, if it does possess them, it is of but little consequence to it, that the county business is transacted at another place. Several illustrations of this opinion may be found in our own state and elsewhere.

From Groton, we passed through Westford to Chelmsford. In the latter town, the Middlesex Canal unites with the Merrimack River. At the junction, are three stone locks through which some boats were passing into the canal while we were there. The time occupied in passing a boat through one lock was about six minutes. . . .

In the issue of the same newspaper is an advertisement of two different lines of stage coaches, which used to run from Worcester to Lowell, one of which went by the way to Groton ; and this was the line taken by Mr. Earle. The advertisement is headed by a cut representing an old-fashioned stagecoach drawn by four horses, with the driver sitting alone on 
the box, and lashing the animals with his long whip. For the information of the curious, I copy it as follows:

$$
[\text { Cut. }]
$$

\section{NEIV ARRANGEMENT}

OF THE LOWELL AND WORCESTER

$$
\text { MAIL STAGE, }
$$

OLD LINE.

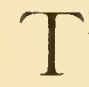

HE Mail Stage will leave Lowell every 'Tuesday, Thursday, and Saturday morning, and pass through Chelmsford, Westford, Littleton, Harvard, Lancaster, Sterling, and West Boylston, to Worcester. Another Stage will leave this at Westford, and pass through Groton and Shirley to Lancaster, where it again unites with this Stage. At Groton seats may be taken in the Stage which passes through Townsend, New Ipswich, Jaffrey, and Marlborough, to Keene.

Rerurning, - Leaves Worcester every Monday, IVednesday, and Friday, at $7, \mathrm{~A}$. MI., and passing on the same routes, will, on its arrival at Lowell, meet with the Boston, Newburyport, Salem, and Haverhill Stages.

At Lancaster this Stage intersects with the Boston and Fitchburg Stage, by which means passages may be had from Worcester and Lowell to Fitchburg, and from Fitchburg to those places.

There will also be an Accommodation Stage, from Lowell to Groton, on Mondays, IVednesdays, Fridays, and Sundays, which will make a daily line from Lowell to Groton, where seats may be taken for Keene every day in the week; passing through Townsend, Ashby, Rindge, Fitzwilliam, Troy, Swanzey, to Keene; and at Fitzwilliam seats may be taken for Brattleborough on Mondays, Wednesdays, and Fridays of each week.

Books kept at Frye's Hotel, in Lowell ; at Batchelder's Hotel, in Belvidere Village ; and at Thomas's, Bannister's, and Worthington's Hotels, in Worcester.

There will be good Coaches and Horses, and careful Drivers. All Baggage at the risk of the owner.

S. Banvister, Agent, Worcester - Dexter Bruce, Agent, Lowell. 
The particulars given in this advertisement suggest many contrasts between the means of travelling seventy-five years ago and the present time. During this period of three-quarters of a century, the facilities of public conveyance have wonderfully improved, but not more than the ordinary comforts of life have increased in the average household. It may be an interesting question to ask whether the human family has improved to the same degree in all those traits and qualities which make up character.

\section{JOHN BOYDEN.}

THE American Antiquarian Society has recently published a Diary kept by Christopher C. Baldwin, one of its former Librarians, wherein he gives an account of a visit made in Boston during the month of January, I 834 . While in the city he tarried at the Tremont House, a hotel which then had been open only for a few years. In describing the noted hostelry, he says : -

The Keeper of this splendid House is Dwight Boyden. His father, Mr. Simeon Boyden, was born in Deerfield, Mass., and is now near 60 years old and lives with his son Dwight. The father of Simeon was John Boyden who was born in Groton, Mass., and died at the age of 88, having for his wife a daught. of Col. [James] Fry of Andover, that old Col. Fry who fought the French and Indians (p. 260).

\section{DR. CHARLES JEWETT WOOD.}

IT may interest some of your readers to know that Dr. Charles Jewett Wood, the father of Major General Leonard Wood, formerly Governor of Cuba, and now Chief of Staff, United States Army, studied his profession at Groton. During a part of the years 1857 and 1858 he was a student under the instruction of Dr. Miles Spaulding, in whose family he lived. At that time Dr. Spaulding occupied the house next 
south of the Brick Store, which was burned on July S, I 892. Mr. Wood attended lectures at the Harvard Medical School during the sessions of $1858-59$ and I 859-60; and in the catalogue of that institution he appears as a resident of Groton, with Dr. Miles Spaulding as his instructor. He received his degree for M.D. from the Eclectic Medical College of Pennsylvania, Philadelphia, in the year I860, an institution now extinct. He began the practice of his profession at Dana, Massachusetts, but soon afterward removed to Hardwick, an adjoining town, where he remained but a short time. While a resident of this place he was appointed Hospital Steward of the Forty-second Regiment of Infantry, Massachusetts Volunteer Militia, then about to leave for the seat of war; and he was mustered into public service on Oct. I4, IS62. $\mathrm{He}$ continued in that capacity until the regiment was mustered out, on August 20, I863. On leaving Hardwick, soon after his return from the army, he took up his abode at Pocasset, a village then in Sandwich, but now a part of the new town of Bourne, where he died on August 25, i880. In the treatment of disease he was eminently successful, and at his death he left the enviable name of a physician who had won the love and respect of his patients.

Dr. Wood was a son of Leonard and Malvina Fitzalan (Reed) Wood, and he was born at Leicester, on February I 8, I829. His father was born at Brookfield, on February 16 , I 802, and his mother at Abington, on May 26, I807; and they were married on April 20, 1828. His mother's mother was Susanna White, a descendant of Peregrine White. The son was married, on July 2I, I 859 , to Caroline Elizabeth Hagar, daughter of Jacob and Sophia (Cutler) Hagar, of Weston; and they have been blessed with three children.

As Dr. Wood at one time called himself a resident of Groton, the town will claim a little reflected honor from the remarkable career of his distinguished son, both as a statesman and a military officer. General Wood is the eldest child of his parents, and was born at Winchester, New Hampshire, on October 9, I860. 


\section{YOUNG LADIES ACADEMY.}

The Young Ladies Academy at Groton, 33 miles from Boston.

W

ILL be open for the reception of pupils, IVednesday, May 7 .

Instruction will be given in the following branches - Reading,

Writing, Orthography, English Grammar, Arithmetic, Ancient and Modern Geography, and plain Needle Work, \$3 per quarter. Add to the above, Rhetoric, Logic, Composition, History, Projection of Maps, Drawing, and Painting, $\$ 4.50$ per qr. or the Elements of Geometry, Astronomy, Natural and Intellectual Philosophy, Chemistry, Botany, French language, fancy and ornamental Needle IVork, $\$ 6$ per qr.

Miss PRESCOTT informs her friends and the public, that several Young Ladies and Misses can be accommodated with board, with her, on reasonable terms, and pledges her most assiduous attention to the health and improvement of all who may be entrusted to her care.

Groton, April 3, I823.

"Columbian Centinel" (Boston), Saturday, April I2, I823.

\section{A RUN-AWAY.}

$R$ an away from the Subscriber, on the 3 ist of January last, an apprentice boy, named Fosiah Lakin, about i 7 years of age, of a middling size, slow of speech, of a spiteful temper, had on a dark home-spun coat, green breeches or white overalls, carried of a gun and bundle of cloths. Whoever will return him to me, shall receive sixpence reward; and I hereby forbid any person harbouring or trusting him on my account, as I will not pay one penny of debt he may contract.

Ephraim Nash, of Groton.

"Independent Chronicle; and the Universal Advertiser" (Boston), February I2, 1789.

\section{ESTATE OF EZRA PRESCOTT.}

All persons indebted to, or have any demands against the estate 1 of Mr. Ezra Prescott, late of Groton, deceased, are desired to exhibit the same to the subscriber in order for settlement.

Westford, August 4 th, 1789 .

Dazid Goodhue, Administrator.

"Independent Chronicle: and the Universal Advertiser" (Boston), August 20, 1789. 


\section{THE GROTON ANCESTRY OF GOVERNOR ANDREIV.}

THE following account, with the footnote, is taken from "The Life of John A. Andrew" (Boston, 1904), by Henry Greenleaf Pearson : -

In the month of July, I $8 \mathrm{I} 7$, Jonathan Andrew brought his bride to his little house in the country town of Windham, Maine. He was a native of Salem, who for the sake of his health had some ten years before settled in Windham near a married sister; now, at thirtyfive, he was the prosperous owner of the "store," where the farmers came to barter. His wife, ${ }^{1}$ a woman of great personal attractiveness, had, strangely enough for those times, pursued her vocation of teacher until the age of thirty-three unmarried. The first child of this union. John Albion Andrew, was born on May 3 I, I 8 I 8.

\section{CURIOUS WORDS AND PALINDROMES.}

THE following article is taken from the Boston Sunday Globe, for April 7, 1907:-

In a letter to the Globe, Dr. Green writes as follows of the interesting words called palindromes. He says :

There are in the English language certain words, and sometimes whole sentences of which the letters composing them, taken either in direct or in reverse order, read the same. Such combinations are called palindromes, a name derived from two Greek words, meaning to run again, that is, the letters run or read backward as well as forward.

When the first man met the first woman - whose name, Eve, by the way, is a palindrome, - he may have introduced himself to her thus: "Madam, I'm Adam." In this supposed case I assume that he spoke English, and not a Garden-of-Edenish dialect, and if my supposition be correct, he made use of a palindromic expression.

1 Nancy Green Pierce, born in Westmoreland, New IIampshire, July 27, 1784, married to Jonathan Andrew on July 14, 88 7 , was the daughter of John Pierce and Sally Farnsworth. Her father was born in Groton, Massachusetts, and was connected with the family of President Franklin Pierce; her mother, born April 12, 1755, was one of the eight children of Deacon Isaac Farnsworth, of Groton, and Anna Green, who were married December 4, I744. (I. I, 2.) 
Among the simple words of this kind or instances of whole sentences, are deed, deified, gog, Hannah, level, minim, redder, nun, repaper, reviver, rotator, sexes, shahs, and tat. "Was it a cat I saw ?" is palindromic.

Barring the spelling, the following sentence may be given: "Lewd did I live \& evil did I dwel." Another example is: "Desserts I desire not, so long no lost one rise distressed." It is said that Napoleon was once asked whether he could have invaded England, when he replied: "Able was I ere I saw Elba." This is a good specimen of a palindrome, but of course the reply was never made, as he would have answered in French. Here is one in Latin : "Subi dura a rudibus." "Endure hard things from the rude."

The following list of five words furnishes a remarkable combination of letters. With one exception they are all Latin words in good repute, and the letters are capable of many regular transformations :

\section{SATOR \\ AREPO \\ TENET \\ OPERA \\ ROTAS}

The first letter of each word, read downward from the top of the list, spells the first word; and the second letter of each word read in the same way, spells the second word; and so on through the list. Beginning at the top of each word, read backward, spells the corresponding word in the list under it, that is, the top word spells the bottom word, the second word from the top spells the second word from the bottom; and so on. Again, beginning at the bottom of the list the last letter of each word, read upward, spells the word at the top ; and in the same way the second letter of each word spells the second word from the top; and so on through the list again.

\section{DR. JOSHUA GREEN.}

THE following obituary notice of Dr. Green was printed in "The New-England Historical and Genealogical Register" (XXX. I26) for January, I 876:-

Joshua Green, M.D., of Groton, Mass., died June 5, I875, at the residence of his son-in-law, Dr. Charles Y. Swan, in Morristown, 
N. J., aged 77. He was a son of Joshua and Mary (Moseley) Green, and was born in Wendell, Mass., October 8, 1797. He was a descendant in the 7 th generation from Percival ${ }^{1}$ Green of Cambridge, through $\mathcal{F} o h n^{2}$, Foseph $h^{3}$, Foseph $h^{4}$, Foshua ${ }^{5}$, and $\mathcal{F} o s h u a^{6}$, his father. A genealogical account of this family in the REGISTER for April, I86 I (XV. 105-9), gives further particulars of his ancestors.

He fitted for college at New Salem, Westfield and Milton academies, and was graduated at Harvard College in the class of r8r8. He studied medicine with Dr. John C. Warren, and, immediately after taking his medical degree, in $\mathrm{r} 82 \mathrm{r}$, was appointed apothecary at the Massachusetts General Hospital, the first year that it was opened for the reception of patients. At that time the apothecary, in addition to his ordinary duties, performed those of house physician and house surgeon. He began the practice of medicine at Sunderland, Mass., in 1823 , and remained there till 1825 , when he removed to Groton. He retired from the active practice of his profession forty years ago.

In 1836 and 1837 , he represented the town of Groton in the Massachusetts legislature. For many years he was a trustee of the Lawrence Academy and secretary or president of the board.

In the summer of $\mathrm{I}_{32}$ he had an attack of pulmonary hemorrhage, which rendered it necessary for him to pass the succeeding winter in Cuba. The trip seemed to restore him to perfect health. For some years before his death he suffered from paralysis, from which disease he died.

He married, Jan. 5, I824, Eliza Lawrence, daughter of Major Samuel and Susannah Lawrence, of Groton. See her obituary, ante, XXVIII. 486, and tabular pedigree of Lawrence, X. 297. They had six children, namely: I. William Lazorence, d. young; 2. William Lazurence, merchant, deceased; 3. Henry Atkinson, merchant, of Boston; 4. Samuel Abbott, M.D., city physician of Boston; 5. Elizabeth Lawerence, m. first, John Kendall (Dart. Coll. i 853); m. second, Charles Young Swan, M.D. ; 6. Foshua, d. young.

$\mathrm{He}$ was admitted to this society as a corresponding member, August i 8, i849. He was much interested in antiquarian and genealogical studies, and was a diligent collector of books and manuscripts illustrating them. He was a subscriber to the REGISTER from its first publication. 


\section{WILLIAM L. GREEN.}

William Lawrence Green, eldest child of Dr. Joshua and Eliza (Lawrence) Green, died at his father's home in Groton, on October 2 I, I 847 . The following notice of him appeared in "The Boston Olive Branch," November 8, I 847, and was written by the late Dr. David Keyes Hitchcock, of Newton.

\section{MR. WILLIAM L. GREEN.}

Died in Groton, Mr. William L. Green, of the firm of Jewett, Tebbetts \& Green, of Boston, aged 2 I years.

One of the most interesting and promising young men in our city has been smitten in death. In the morning of life, in the midst of usefulness, surrounded by a large circle of devoted friends, the manly form has been laid low by the King of Terrors. Disease which before had never visited him, soon assumed a dangerous form; and in a few days - and to his affectionate relatives, days of anxious fear and hope - life's silver cord was loosed and the golden bowl was broken!

Bitter as is this bereavement, it cannot but be a sweet consolation to the afflicted parents to know, that though death has deprived them of a most amiable, affectionate and beloved son, it cannot rob them of the sweet recollections of his virtues or the sacredness of his memory; for as deep as the wounds which this bereavement has made, are they embalmed in their hearts, where time shall neither deface nor erase them, but where they shall live forever.

The funeral of the deceased was numerously attended, and among those assembled were to be found a number from the city. The Rev. Mr. Phelps, of G, made an appropriate address and a very impressive prayer, and all present seemed to feel that they were in the "house of mourning." As the tear stole down the cheeks of those who came to pay their last tribute of respect and affection to the memory of the departed, the silent prayer ascended to heaven in behalf of the sorrowing parents, that they night be sustained in this their hour of trial and sadness, and that it might work out for them " a far more exceeding and eternal weight of glory." 


\section{HENRY A. GREEN, ESQ.}

THE following notice of Mr. Green appeared in the "Saturday Evening Gazette" (Boston), January I0, I89I, and was written by the editor, Colonel Henry Grosvenor Parker, who had been his friend for many years:-

- Forty years ago no more striking figure could be seen in Boston streets than that of Mr. Heury Atkinson Green. Commanding in stature, graceful in movement, elegant in dress, there was in every manifestation of the man the unmistakable air of gentleman. Men and women alike turned to look at and admire him. In those days there was a Boston aristocracy that was a real one, and the rest of mankind were separated by a dividing line so marked as to amount to a distinction of caste, as it were, between the few who composed the charmed circle and the many worthy people who were clearly outside it. This barrier was broken by the war of the Rebellion, when the heart of the aristocratic mother and that of the democratic mother bled alike over the sacrifice of their own, and when humanity and brains asserted themselves above and beyond the accident of position, and the rich men of that day and their descendants became the poor men of a later time. Mr. Green was in the charmed circle and of it. He was a Lawrence, a favorite in society, and one of the earlier members of the Somerset Club. But he was also a man among men, educated himself to trade, mastered the dry goods commission business in the house of Wilkinson, Stetson \& Co., in Federal street, and in that of Tucker, Newton \& Mills, in which he became a partner, and continued so in the firm's changes (Mackintosh, Greer \& Company) until his death; all the while "a hail fellow well met" with the tiade, popular with buyer and seller, a kind friend to the "younger boys in the store," an excellent salesman, a careful dealer, and a wise and conservative investor of his own earnings. His manner was frank, and his voice was at once manly and musical. It was a distinct, emphatic sound, and not an aspiration. It was magnetic in its quality. Mr. Green made his own fortune. He was not above work, and always honored intelligent workers. He was fond of music and the theatre and the last novel, but never cared much for society, so called. His impulses were kindly in every relation of life. He detested a snob, especially a poor and incapable one. He had no patience with a sham of any kind. Among his warmest friends 
were the strongest business men in Boston, whose judgment he respected and whom, though not in his line of life, he was glad to meet in all places and under any circumstances. Mr. Green had long been warned that he was a minute man, but his end was sudden when it came. His last two years, made happy in many ways, were quiet, thoughtful, elevating. His religion was simply "Do unto others as you would that others should do to you." It is singular that his favorite cousin, Mrs. William IV. Tucker, should have died in Paris on the same day [January 8]. Mr. Green's funeral took place yesterday [January Io] at ro o'clock, at his late residence, No. I เo Newbury street, and was largely attended. After the simple service of the Episcopal Church, the remains were taken to Groton, for interment in the family lot.

Henry Atkinson Green, Esq., died at his residence in Newbury Street, Boston, on Jan. 8, i $89 \mathrm{I}$. He was a son of Dr. Joshua and Eliza (Lawrence) Green, and born at Groton, on April 29, 1828 . He was educated at the academy in his native town, and in 1846 came to Boston to live. At the time of his death, and for many years previously, he was a member of the firm of Mackintosh, Green $\&$ Co. His wife, Mrs. Emily (Wagner) Green, died on Jan. 4, r 885 . Mr. Green left two married children: Mrs. Caroline Sargent Green, wife of William Amory Meredith, of London, England; and William Lawrence Green, of Albany, N. Y. The interment took place at Groton.

"The New-England Historical and Genealogical Register" (XLV. 173) for April, I89I.

\section{INCORPORATED INSTITUTIONS OF LEARNING.}

LAWRENCE ACADEMY, founded in I792, was incorporated as Groton Academy on September 28, I 793. The present name was given by Special Act passed on February 28, I $\$ 46$.

The Groton School, opened in October, I 894 , was incorporated by an Act passed on March 17, I 893 .

The Lowthorpe School of Landscape Architecture, Gardening and Horticulture for Women was incorporated, under the 
general law, on December 17,1909 . The proposal to establish the school, dated on September II, I90I, was issued by Mrs. Edward Gilchrist Low.

\section{HON. GEORGE S. BOUTWELL.}

Governor Boutwell was born at Brookline, Massachusetts, on January 28, I 8 I 8 , and at the time of his election was under thirty-three years of age.

It is somewhat singular that there have been six other Governors of Massachusetts born in the same year as Mr. Boutwell; and they are as follows:-

William Claflin, born at Milford, on March 6.

John Albion Andrew, born at Windham, Maine, on May $3 \mathrm{r}$.

Henry Joseph Gardner, born at Dorchester, on June r 4.

Alexander Hamilton Rice, born at Newton, on August 3 .

Thomas Talbot, born at Cambridge, New York, on September 7 .

Benjamin Franklin Butler, born at Deerfield, New Hampshire, on November 5 .

All these men are now dead. Between $185 \mathrm{I}$ and 1883 , inclusive, a period of thirty-three years, the administrations of these several Governors covered an interval of eighteen years.

\section{MR. AND MRS. SAMUEL A. SHATTUCK.}

THE following tributes were paid to the character of Mr. and Mrs. Samuel A. Shattuck by one who knew them both intimately. In his opinion they each represented the highest type of Christian character. As a mark of respect and affection this volume is inscribed to their memory. The first notice is found in the "Boston Evening Transcript" (p. 15), September 13, 1905; and the other in substance 
appears in the issue of the same newspaper (p. 5), December 9, 1908 .

Mr. Samuel Augustus Shattuck died suddenly at Groton, on Monday, Sept. 4. He was an only son of Luther and Polly Prescott (Sawtell) Shattuck, and was born on Oct. 27, I825. A native of Groton and a life-long resident, he was well known throughout the neighborhood, and no one in the town had a higher reputation for integrity and honesty and for all the virtues which make up Christian character. He was brought up on a farm and always followed the calling of a farmer. He might have held any office in the gift of his neighbors, but his innate modesty was such that he could never be induced to accept a public position. His mission, which he fulfilled completely, was to serve as a conspicuous example of that silent influence which actions rather than words exert on the life of friends and others. The words of Tennyson might well be applied to him :

Kind hearts are more than coronets, And simple faith than Norman blood.

Mrs. Sarah Parker Shattuck died, after a long and painful illness, at Groton, on Tuesday [December 8]. She was a native of that town, where she was born on January $2,1 \delta_{3}$, and where her family had lived for many generations. She was a distant kinswoman of her husband, and before her marriage they both bore the same family name. Mrs. Shattuck was an active member of the Congregational Church and was connected with various social and religious organizations in her neighborhood. She will be greatly missed in the town, where her counsels, often needed and always freely given, were so helpful. Her husband died three years previously, and she leaves no children. 
I N D E X. 



\section{N D E X.}

A

Academy, Young Ladies, 194.

Ames, Joel, I 47.

Andrew, John Albion, Groton ancestry of, 195 .

Animals, wild, 77-79.

A pple-trees, age of, 76 .

Avery, William, minerals in Groton, $83-86$.

\section{B}

Bainbridge, Commodore William, and the Lakin farm, I49, 150.

Baptistery, 94.

Batchelder, Charles Foster, mockingbirds found in Groton, 8I, S2.

Bigelow School, Boston, I2I.

Billerica Bridge, I 24-I 28.

Birds, 32-42.

Blotter of 1802 , 109 .

Blowth, 74, 75 .

Bog-ore, 92-94.

Boutwell, George Sewall, Governor, 201 ; cultivation of hops, 65,66 ; shade and ornamental trees, 8S-92.

Boyden, John, 192.

Bridges, Middlesex County, I39-I4I.

Brooks, 57-59.

Browne, Thomas, dish-turner, 76 .

Building, a "raising," I 54 .

C

Candles, tallow-dips, 97 .

Causey, 74 .

Celebrations, July 4, ISO7 and 1808 , I72-I 77 .

Chamberlain, Edward G., mountains seen from Gibbet Hill, 66-59.
Chelmsford, foundry at, 93 .

Circus and the show, $145,146$.

Coal, hard, 96.

Cooper, Samuel, diary, 1775 , 1776 , IS7, IS8.

\section{D}

Dark Day, I780, I4I-145.'

Dates of local interest, $\mathrm{IO}_{3}, \mathrm{IO}_{4}$.

Davis, John, inscription on boulder, I 58 .

Deed, of $1674,129,130$.

Deer, wild, ro5-107.

Dish-turner, 76 .

Douglass, William, Summary, 79, So.

\section{E}

Edward, Prince, visit to Groton, 1794 , I 8 I.

\section{$\mathrm{F}$}

Families, instances of large, 172.

Family, aftlicted, I85, I86.

Fauna, 25-74.

Federalists, celebrations, ISO7, ISo8, 172-177.

Fish, 29 .

Flint, Abigail, deed of 1674,129 .

Flora, I-26.

Flowers and plants, 6-20.

Foundry, Chelmsford, 93.

Fox, silver-gray, 83 .

Freshet, $1751,108$.

\section{G}

Garfield, Benjamin, 152.

Geography of Groton, 46-69, 94-96. 
Gibbet Hill, I 7, I IS.

GilbbetHill, mountains seen from, 66-69. Glacial striation, 105.

Governors born in ISIS, 201.

Green, Henry Atkinson, 199, 200.

Green, Joshua, I 96, 197.

Green, William Lawrence, 198.

Groton, name of, I 52-1 54.

Groton WVater Company, 98.

\section{$\mathrm{H}$}

Hallbeck, Axel C., moat, 73.

Hartwell, Edward Mussey, moat, 70-73. Hazen, Benjamin, a naval hero, I $5 \mathbf{I}$.

Hill, Elizabeth Sewall, flora and fauna of Groton, I-45.

Ifills, 53-55; height of some Groton, 99.

Hollis, N. H., old deed of 1674,129 , I 30.

Hops, cultivation of, 65,66 .

Housen, 74.

Howe, Lucinda, 147.

Iuse, Mrs. Rebecca, I6€-r68.

\section{I}

Incorporated institutions of learning, 200.

Independence Day celebrations, 1807 , 1808, 172-177.

Indian words, list of, $178-\mathbf{I} S_{I}$.

Insects, 27-28.

Inscriptions, historical, I 57, I 58.

Iron, bog-ore, 92-94.

\section{J}

James's Brook, 130, 131

\section{L}

Lakin, Josiah, I94.

Lakin Farm, Commodore Bainbridge and the, I 49, I 50.

Lawrence Academy, established 1792, I $S_{2}-1 S_{4}$.

Lawrence School, Boston, I2 I.

Leach-tubs, 82 .

Light, reflection of, $\mathrm{IS}_{4}, \mathbf{r} 85$.
Longevity, instances of, 16:-170.

Longley, William, inscription on monument, 157 .

\section{MI}

Mail-stage, Lowell and Worcester, I9I, I92.

Mammals, $43-45$.

Meadows, 55-57.

Meeting-house, inscription on tablet, I $899,15 \mathrm{~S}$; on monument, 157.

Mile-stones, Groton, I 59-164.

Mill-sites, old, I 2 I-1 24.

Minerals, by Dr. William Avery, $S_{3}-S 6$. Ministers of Groton, after Mr. Dana's dismissal, ז $186-\mathbf{I S g}$.

Mistake, odd, I 47.

Moat, by E. M. Hartwell, 70-73.

Mocking-birds, $S_{1}$, 82

Mountains seen from Gibbet Hill, 6669.

\section{$\mathrm{N}$}

Names, fashion in given, $15^{8}, 159$.

Natural History of Groton, 1-45.

Neck, the, I08, rog.

Oxen, 120.

\section{$\mathrm{P}$}

Palindromes, curious words and, 195, Ig6.

Pillion, use of a, 75 .

Plants, 6-20.

Plates, wooden, 76 .

Ponds, 47-53.

Prescott, Ezra, estate of, 193.

Prescott, Col. William, inscription on monument, I 57.

\section{Q}

Quarry, soapstone, I I4-I I6.

\section{$\mathrm{R}$}

Railroad meetings, r70, I7 I.

Raising, a, I 54 .

Reptiles, 30, 3 I.

Residents, prominent, 147.

Rivers, 46-47. 
Roads, 60, 6I ; highway from Groton $\mid$ Tornado, destructive, IS21, rog-II 4. to Concord, I37, I 38 ; some, and Trees, 21-26; growth of, 100 ; shade streets, I I -120 ; highway to Chelmsford, 138 , I39; to the West, So; two thoroughfares to Boston, I34I 36.

Rockwood, Mrs. Sarah (Chaplin), 147, 14 S, $164-166$.

Run-away, a, I94.

$\mathrm{S}$ and ormamental, SS-92.

Trip from Worcester to Lowell, IS9I9I.

Trumbull, James Hammond, on Indian name of Groton, I79, ISo.

\section{V}

Vertebrata, 29-45.

IV

Salmon, in Nashua River, 73.

Shattuck, John, an aftlicted family, I85, I $\$ 6$.

Shattuck, Samuel Augustus, 20I, 202.

Shattuck, Sarah Parker, 20I, 202.

Soap, and leach-tubs, Sz.

Soapstone Quarry, I I4-I I6.

Stage, mail, Lowell and IVorcester, I9I, I92.

Stevens, Camp, at Groton, I3 I-I 33 .

$\mathrm{T}$

Tallow dips, 97.

'Tomato, introduction of the, 103.

Y

Young Ladies Academy, 194. 




